\title{
Turistične atrakcije
}

Ksenija Vodeb

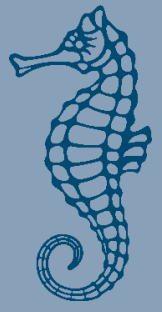


University of Primorska Press

Editorial Board

Gregor Pobežin

Maja Meško

Vito Vitrih

Silva Bratož

Aleksandra Brezovec

Ana Petelin

Janko Gravner

Krstivoje Špijunović

Miloš Zelenka

Jonatan Vinkler

Alen Ježovnik

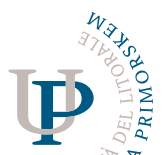

UNIVERT 


\section{Turistične atrakcije}

Ksenija Vodeb

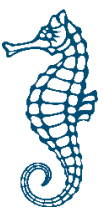




\section{Turisticne atrakcije}

Ksenija Vodeb

\section{Recenzenta}

Mateja Sedmak

Jana Hojnik

\section{Lektor: Davorin Dukič}

Prelom: Špela Lipanje, Špela Maslo, Sašo Arnejčič

Priprava za izdajo: Jonatan Vinkler

\section{Izdala}

Založba Univerze na Primorskem

(za založnika: prof. dr. Dragan Marušič, rektor)

Titov trg 4, SI-600o Koper

\section{Glavni urednik}

Jonatan Vinkler

Vodja založbe

Alen Ježovnik

Koper 2018

ISBN 978-96I-7055-I0-8 (pdf)

http://www.hippocampus.si/ISBN/978-96I-7055-10-8.pdf

ISBN 978-96I-7055-I I-5 (html)

http://www.hippocampus.si/ISBN/978-96I-7055-I I-5/index.html

DOI: https://doi.org/10.26493/978-96I-7055-10-8

(C) 2018 Univerza na Primorskem

Izdaja je sofinancirana po pogodbi ARRS za sofinanciranje izdajanja znanstvenih monografij v letu 2018 .

Kataložni zapis o publikaciji (CIP) pripravili v Narodni in univerzitetni knjižnici

v Ljubljani

COBISS.SI-ID $=296890880$

ISBN 978-96I-7055-I0-8 (pdf)

ISBN 978-96I-7055-I I-5 (html) 


\section{Vsebina}

7 Uvod

9 Definiranje osnovnih pojmov

9 Turistični viri (definiranje, vloga, značilnosti)

I4 Komparativne in konkurenčne prednosti

I8 Definiranje pojma turistična atrakcija

25 Koncept turistične atrakcije

25 Razumevanje koncepta turistične atrakcije z vidika družbenega konteksta in kritične teorije turizma

30 Leisure class - brezdelni razred

33 Sistem turistične atrakcije

34 Leiperjev sistem turističnih atrakcij

4I Model turistične atrakcije

47 Evolucija turistične atrakcije ali MacCannellov proces sakralizacije

5I Zgodovinski razvoj turističnih atrakcij

5I Izhodišča obravnave turističnih atrakcij skozi čas

54 Zgodovinske prelomnice v razvoju turističnih atrakcij

65 Razvrščanje atrakcij

75 Turistični vplivi in turistične atrakcije

76 Vrste turističnih vplivov

84 Značilnosti turističnih vplivov

86 Razumevanje, načrtovanje in upravljanje turističnih vplivov 
Turistične atrakcije

93 Upravljanje in organizacija turističnih atrakcij

97 Valorizacija turističnih virov

IO2 Atrakcija kot turistični proizvod ali turistična izkušnja

107 Trendi v razvoju turističnih atrakcij

III Zaključek

II5 Povzetek

I2I Summary

127 Literatura in viri

135 Imensko kazalo 


\section{Uvod}

Turistične atrakcije v sodobnem času so često predmet strokovnih in laičnih razprav, na splošno je turizem polje interesa mnogih. Zdi se povsem razumljiv in samoumeven, nič kaj resen ali zahteven, saj na lica ljudi izvabi nasmeh ob prijetnih občutkih in spominih. Vsi smo radi turisti, radi potujemo, raziskujemo in spoznavamo nove kraje. Biti na drugi strani, ukvarjati se s ponudbo v turizmu pa je nekaj povsem drugega. Ljubezen do potovanja, navdušenost nad turizmom in ljudmi je nasploh osnova za uspeh v tem »poslu «, a razumevanje in upravljanje turizma zahteva prav specifična znanja, sposobnosti, veščine in čustveno inteligenco. Problematika in neučinkovitost turizma v gospodarskem, družbenem ali okoljskem smislu nakazuje, da je poznavanje in razumevanje turizma, njegovih značilnosti in specifike veliko zahtevnejše, kot se zdi na prvi pogled ali kot laična javnost pogosto površ(i)n(sk)o vidi in ocenjuje.

$\mathrm{V}$ tej knjigi obravnavamo osnovno celico turizma - turistično atrakcijo. Kot jo definirajo mnogi avtorji (Gunn, 1997; Mill in Morrison, 2002; Kretzschmar, 2009; Sharpley, 2009), je to vitalni organ turizma, njegova gonilna sila. Zato v knjigi obravnavamo koncept turistične atrakcije, njen pomen $\mathrm{v}$ turizmu in njeno vlogo $\mathrm{v}$ okviru turistične destinacije in turizma. Prav tako se posvečamo razlogom, obsegu in možnostim za razvoj in upravljanje turističnih atrakcij. Brez turistične atrakcije ni turizma, kajti ta je iniciator vsake turistične aktivnosti. $Z$ vidika turističnega potrošnika pa je atrakcija motiv potovanja, obiska ali doživetja. Relacije med turistično destinacijo in turistično atrakcijo so mnogotere, nenazadnje je atrakcija na trgu in v konceptualnem smislu lahko tudi destinaci- 
ja sama. Kdaj in pod kakšnimi pogoji je temu tako, ugotavljamo in obravnavamo v nadaljevanju.

Povezave in podobnosti med atrakcijo in destinacijo bomo obravnavali tudi v širšem kontekstu in opozorili na dejstvo, da imata oba koncepta neke skupne značilnosti ter da veljajo zanje enaki pogoji, kar zadeva delovanje in upravljanje. Kritično bomo obravnavali tudi najpogostejše zmote in prepričanja laične pa tudi (žal, prepogosto) strokovne javnosti. Zmote same po sebi še niso škodljive, vendar je lahko za strokovno javnost oz. turistično stroko, ki upravlja in ustvarja turizem, napačno prepričanje o in razumevanje teh osnovnih konceptov v turizmu razlog za slabšo učinkovitost, konkurenčnost in uspeh na turističnem trgu. Pri omenjenih $\gg$ zmotah $\ll$ bomo posebej opozorili na razlikovanje med turističnimi viri in turističnimi atrakcijami, komparativnimi in konkurenčnimi prednostmi, turistično atrakcijo in destinacijo.

Znamenitosti, kot posplošeni sintagmi našega govornega področja, pa bomo namenili še več pozornosti, saj je nejasna predstava o tem lahko posledica slabše konkurenčnosti v turizmu nasploh.

Knjiga je namenjena študentkam in študentom turizma, raziskovalcem in profesorjem, strokovnjakom s področja turizma iz prakse, pa tudi širši javnosti. 


\section{Definiranje osnovnih pojmov}

O turističnih atrakcijah ne moremo govoriti, ne da bi govorili o turističnih virih, ki so osnova za nastanek atrakcij. Turistične vire torej razumemo kot surovino, potencial ali bazo za oblikovanje turistične atrakcije. $\mathrm{V}$ tem poglavju je cilj opredeliti turistične vire, njihove značilnosti in naravo, njihovo vlogo v turizmu oz. na destinaciji kot osnovni turistični enoti. Opredeljene bodo komparativne in konkurenčne prednosti ter razlike med tema dvema konceptoma $\mathrm{z}$ vidika turističnih virov in turističnih atrakcij. Do definiranja pojma turistična atrakcija bomo prišli preko geneze turističnih virov in procesa valorizacije, potrebnega za njihovo vzpostavitev.

\section{Turistični viri (definiranje, vloga, značilnosti)}

$\mathrm{V}$ turizmu zelo pogosto razpravljamo o turističnih virih ali resursih kot zagotovilu turističnega uspeha in ničkolikokrat se dogaja, da se te razprave zaključijo z domnevnim paradoksom: razpolagamo z bogatimi turističnimi viri, a v turizmu nismo temu ustrezno uspešni. Paradoks je seveda samo utvara, saj uspeh v turizmu nikakor ni pogojen zgolj s turističnimi viri. Ti naj bi bili le osnova za ustvarjanje atrakcij, ki pa to postanejo in obstajajo na podlagi učinkovitega načrtovanja, razvoja in upravljanja, to pa je $\mathrm{v}$ domeni turističnega ali destinacijskega menedžmenta. $\mathrm{V}$ turistični praksi, tudi pri nas, je na žalost premalo strokovnega znanja in razumevanja teh konceptov, kar je povečini tudi razlog nižje ekonomske učinkovitosti v delovanju turistične atrakcije. 
Problematika terminološke zmede, kjer ne razločimo jasno turističnih virov od turističnih atrakcij, postaja omejitev v gradnji funkcionalnega sistema turistične atrakcije, kar je vezano na strateške cilje in naloge tega sistema (Kušen, 20I0). Sistem turistične atrakcije bomo natančneje opredelili v nadaljevanju, tukaj pa definiramo osnovne pojme naše obravnave.

Turistični viri so lahko v nekem geografskem območju različni in številni, pretežno pa gre za družbene, kulturne, naravne, gospodarske, industrijske, zgodovinske in druge vire. Namreč, turistični viri ne obstajajo sami po sebi, temveč so vedno del že obstoječih dobrin, ki pa jih lahko uvrstimo med zgoraj navedena področja. Turistični postanejo, ko jih za turistične »označimo«, ko jih prepoznamo kot turistične potenciale. Ker so turistični viri družbeni fenomen in konstrukt, je jasno, da jih ustvarja in pogojuje družba, prav tako pa spremembe v družbi bistveno vplivajo na spremembe turističnih virov. $\mathrm{O}$ tem, kako turistične vire pogojuje družba, bo več govora v drugem poglavju. Torej, turistični viri so v osnovi del družbenih, gospodarskih, industrijskih, zgodovinskih in drugih virov, zato je zelo pomembna konstruktivna povezava med turizmom in temi področji. Pomenu teh povezav se bomo prav tako posvetili nekoliko kasneje.

Turistične vire lahko definiramo kot naravne ali antropogene dobrine, ki se lahko gospodarsko valorizirajo. So del nekega geografskega in družbenega območja (regije ali države), njihovov bogastvo pa predstavlja komparativno prednost $\mathrm{v}$ gospodarskem oz. turističnem razvoju neke države. Kušen (2000) jih definira kot potencialne in realne turistične privlačnosti, mednje všteva turistično infrastrukturo in superstrukturo, potovalne agencije, turistično organiziranost destinacije, turistične kadre in podobno. Turistični viri so ključni motiv za turistično potovanje ali obisk. Predstavljajo bistvo privlačnosti destinacije, potencial, na katerem lahko temelji razvoj nekega prostora ali dejavnosti. Turistični viri predstavljajo del gospodarskih virov neke države in vsa tista sredstva, ki so v turizmu nekega območja lahko koristna. Tako kot je destinacija jedro turističnega sistema, so turistični viri oz. turistične privlačnosti jedro turistične destinacije. Predstavljajo najpomembnejši del destinacijskega ali turističnega proizvoda. Svoje lastnosti ter identiteto prenašajo na identiteto same destinacije. Po njih je destinacija prepoznavna na turističnem trgu. Turistični viri so potencialne turistične privlačnosti, ki to postanejo $s$ turistično valorizacijo (prisotnostjo na trgu, distribucijo, trženjem itn.). Privlačnosti morajo biti informativno in prometno dostopne. Zato je vsaka turistična privlačnost v svoji osnovi turistični vir, vendar vsak turistič- 
ni vir ni nujno že tudi turistična privlačnost: vir brez dostopa in brez turistične valorizacije namreč ni turistična privlačnost (Vodeb, 20I4).

Prepričanje ekonomske geografije je, da viri ne obstajajo kar sami po sebi, ampak nastajajo in so ranljivi. Dragoceni pa so, ker lahko ustvarjajo bogastvo. Turistični vir, valoriziran v privlačnost, kot največjo prednost turistične industrije vidita tudi Sotiriadis in Loedolff (2015). Ob uspešnem menedžmentu lahko potencialne turistične vire v procesu turistične valorizacije preoblikujemo v turistične privlačnosti. Tako lahko postanejo konkurenčna prednost neke destinacije. Izzivi upravljanja v turizmu se kažejo v dejstvu, da turizem praviloma nima izključno svojih »surovin« (temeljnih virov); te si deli z drugimi dejavnostmi, včasih konstruktivno z dopolnjevanjem in s sodelovanjem, včasih destruktivno s konflikti in z nesporazumi. Vzrok je velikokrat zakonodaja, ki opredeljuje dobrine klasičnih dejavnosti (kmetijstvo, gospodarstvo, industrija), ne pa turizma kot dejavnosti, zato je težje upravljati z dobrinami ali viri v »skupni« rabi. Razvoj ene dejavnosti (industrija, obrt, kmetijstvo, energetika) velikokrat vpliva na uničenje virov druge dejavnosti (turizem - onesnažena voda in zrak, hrup itn.). Turistično gospodarstvo zato mora zaščititi temeljne turistične vire (potencialne in realne privlačnosti). Obstajajo t. i. registri turističnih privlačnosti, razvojni in tržni načrti turizma, destinacijski menedžment, ki naj bi skrbel za zaščito in ohranjanje turističnih virov v destinaciji skupaj z drugimi akterji s področja turizma in tudi s tistimi, ki se s turizmom povezujejo.

Turistične vire zagotovo pogojujejo turistični trendi. Dokazana je namreč dialektična povezava med razvojem človeške družbe in razvojem turizma. Skozi različna obdobja so se pričakovanja in zahteve turistov spreminjali, s tem pa tudi pomagali »oblikovati« turistične proizvode neke destinacije. Turist v postmoderni dobi od destinacije pričakuje precej več kot samo sonce, morje in pesek. Naravni viri neke destinacije torej ne zadovoljijo sodobnih trendov turističnega povpraševanja. Trendi se nagibajo $\mathrm{k}$ individualizirani, vrhunski storitvi, ki vključuje tudi aktivnosti, šport, rekreacijo, kulturo ali umetnost. Novi turizem zahteva avtentično izkušnjo, ki omogoča stik z lokalnim prebivalstvom in uživanje v izvirnem okolju. Turistični trendi nakazujejo potencialne turistične vire. Ko turistično gospodarstvo začne angažirati turistično ponudbo, vanjo vključuje turistične vire, ki s turistično valorizacijo (ta vključuje tudi trženje ponudbe) postanejo turistične privlačnosti. Turisti zanje vedo, so jim dostopne, jih kupujejo, konzumirajo in priporočajo svojim prijateljem. Te turistične privlačnosti $\mathrm{v}$ smiselnih vsebinskih kombinacijah predstavljajo turistične proizvode, ki pa tvorijo integralno turistično ponud- 
bo turistične destinacije. Wilkinson (2001, v Howie, 2003) meni, da je vire treba $\gg$ razviti «, da bi pridobili $\gg$ koristnost $\ll \mathrm{v}$ turističnem smislu. To razvijanje virov ni nič drugega kot njihova valorizacija; proces, v katerem viri pridobijo dodano vrednost, turistični namen in uporabnost, lahko zadovoljijo turistično povpraševanje in so namenjeni nekemu ciljnemu segmentu. Wilkinson (200I) tako vire definira kot elemente naravnih dobrin, ki šele v kombinaciji vlaganja znanja, tehnologije ter individualnih in družbenih ciljev lahko postanejo viri, ki zadovoljujejo potrebe obiskovalcev in turistov. $S$ tem »kombiniranjem « viri pridobivajo dodano vrednost, vsebino, smisel in lahko postanejo del integralne turistične ponudbe.

Nedvomno so turistični viri bistvo, esenca turistične privlačnosti, ki predstavlja tudi glavni motiv, razlog obiska turistov. Zato o njihovem pomenu za turizem ne gre dvomiti, še več, zavedati se je treba njihovega ključnega prispevka pri učinkovitosti turizma. O tem je prepričan Kruczek (2015), ko pravi, da so turistične atrakcije ključni element turističnega gospodarstva, saj spodbujajo potovanja na destinacije in zagotavljajo zadovoljstvo obiskovalcev. Tudi številni drugi avtorji (Swarbrooke, 200I; Watson in McCracken, 2002; Fyall, Leask in Garrod, 2002; Middleton, Fyall, Morgan in Ranchhod, 2009; Weidenfeld, Williams in Butler, 2010; Sotiriadis in Loedolff, 2015) izpostavljajo gospodarski pomen turističnih atrakcij, saj naj bi bile te sestavni del turistične industrije, ker predstavljajo fokus vsake turistične aktivnosti, vplivajo na potovalne odločitve in so ključni element turistične izkušnje. Vloga atrakcij pri povečevanju poslovnih priložnosti, trajnostnemu razvoju destinacij in splošni gospodarski regeneraciji nekega območja ni tako redek primer, o čemer priča Smale (2006, v Leask, 2008). O bistveni vlogi turističnih atrakcij za razvoj in uspeh turizma destinacije poročata Leask (2008, str. II), ko pravi, da so atrakcije »ključno orožje $\mathrm{v}$ konkurenčnem boju « turističnih destinacij, in Swarbrooke (1999, str. 267), ko atrakcije poimenuje »srce turistične industrije « ter jim tako pripiše vitalno funkcijo pri doseganju konkurenčnosti turizma. Sotiriadis in Loedolff (2015) pa učinkovitost menedžmenta turističnih atrakcij vidita kot sestavni del destinacijskega menedžmenta na podlagi poročanj Fyalla, Garroda, A. Leask in Wanhilla (2008) ter Weidenfelda idr. (2010) o izboljšanju kakovosti storitev in turističnega doživetja ter marketinške in menedžerske učinkovitosti kot posledici partnerskega sodelovanja in mreženja v turizmu.

Turistični viri kot taki imajo tudi določene lastnosti in identiteto, ki pa jih odločilno odražajo (zrcalijo) na destinacijo in destinacijski proizvod. To dejstvo je za turistični ali destinacijski menedžment zelo ko- 
ristno, saj je lahko pomemben del marketinške strategije in pozicioniranja na turističnem trgu. Tudi Kruczek (2015) je prepričan, da atrakcije omogočajo identifikacijo mest in regij s tem, da opredeljujejo njihovo identiteto in javno podobo.

Sklenemo lahko, da je turistični vir v vsakem primeru sestavina, potencialna za razvoj turistične privlačnosti, saj predstavlja najvažnejši del turističnega proizvoda, njegovo jedro. Vsaka turistična privlačnost je turistični vir, vendar vsak turistični vir ni nujno tudi turistična privlačnost (Kušen, 2000). Ta trditev govori o kronologiji turističnega vira in nastanku turistične privlačnosti iz vira, kar bomo potem obravnavali v kontekstu geneze turističnega vira in njegove valorizacije pred transformacijo $\mathrm{v}$ turistično privlačnost. Kušen namreč opozarja na pomembno razliko med enim in drugim. Poznavanje in razumevanje teh razlik je pomembno zagotoviti pri načrtovanju ter upravljanju turizma zaradi doseganja učinkovitosti in uspeha na turističnem trgu. Uspeh turizma destinacije se meri s sposobnostjo menedžmenta $\mathrm{v}$ procesu valorizacije turističnih virov, uspešne turistične atrakcije pa so lahko izjemna ali tudi primarna konkurenčna prednost za destinacijo. Kruczek (2015) tako razpravlja o t. i. vodilnih atrakcijah (ang. flagship attractions), ki so obravnavane kot instrument gospodarskega razvoja destinacije, pomenijo pa najboljšo in najpomembnejšo atrakcijo, ki je na nek način edinstvena, mednarodno pomembna in prepoznavna ter zaradi določene velikosti in gospodarskih učinkov sodi v to kategorijo. Dinamiko valorizacije turističnih virov pa narekuje povpraševanje, saj lahko, dokler po določenem viru ne obstajata potreba, interes ali zahteva na strani povpraševanja in zatem angažma menedžmenta v oblikovanju ponudbe, govorimo le o potencialnih virih.

Značilno za turistične atrakcije je, da so izjemno kompleksne (Kruczek, 2015), da so v tesni povezavi z drugimi področji in sektorji (Leask, 2008), imajo tendenco razdrobljenosti (Sotiriadis in Loedolff, 2015) in skupne lastnosti s turistično destinacijo (Vodeb, 20I4), saj predstavljajo njen podsistem. Slednja značilnost je povezana z Leiperjevim modelom sistema turistične atrakcije, o katerem bo govora $v$ enemu od naslednjih poglavij in ob katerem lahko korektno razložimo potovalno izkušnjo po fazah pa tudi celoten turistični sistem. Značilnost turističnih atrakcij je tudi to, da jih je potrebno upravljati, da morajo biti informativno in fizično dostopne, da jih je potrebno tržiti in razvijati, kot vsak turistični proizvod, da imajo svojo življenjsko dobo. Poleg tega je njihova indikativna značilnost stalna dinamika, torej da imajo spremembe, ki nastajajo $\mathrm{v}$ družbenem gospodarskem, tehnološkem, političnem in drugih okoljih, 
nedvomno velik vpliv na turistične atrakcije. Spremembe so lahko gonilo razvoja, razvoj pa je v rokah menedžmenta.

\section{Komparativne in konkurenčne prednosti}

Ekonomska teorija razlikuje komparativne (primerjalne) in konkurenčne prednosti. Primerjalne prednosti izhajajo iz naravnih virov države, konkurenčne pa iz sposobnosti države, da tem virom ustvari dodano vrednost (Mihalič, 2002). Tudi WEF (World Economic Forum) v svojem modelu konkurenčnosti poudarja, da je konkurenčnost države v njeni sposobnosti dolgoročnega oblikovanja in vzdrževanja ekonomske dodane vrednosti (economic value-added) (Ritchie in Crouch, 1993, str. 26). Večje število konkurenčnih dejavnikov, ki jih država omogoča svojim podjetnikom, pomeni bolj usposobljen in uspešen boj za preživetje na trgu. Zato pravimo, da primerjalne prednosti temeljijo na bogatih naravnih virih države, kot je npr. nafta, medtem ko konkurenčne prednosti temeljijo na sposobnostih podjetnikov, da tem virom ustvarijo dodano vrednost, v tem primeru z rafiniranjem nafte. Če to opredelitev razlikovanja prenesemo na mednarodni turizem, lahko trdimo, da so primerjalne prednosti ugodno podnebje, lepa pokrajina, privlačne plaže, neokrnjena narava, konkurenčne prednosti pa so turistična infrastruktura (hoteli, prireditve, privlačnosti, transportna mreža), kakovosten menedžment, spretnosti in znanje zaposlenih, turistična politika itn.

Naravni viri države so $\mathrm{v}$ mednarodnem turizmu prav gotovo pomembna primerjalna prednost, saj turist s seboj navadno odnese doživetje teh virov (pokrajina, podnebje, gore itn.). Ne smemo pa primerjalnih prednosti zožiti zgolj na naravne vire in potenciale za turizem; v to kategorijo nedvomno sodijo tudi vsi drugi potencialni viri (kulturni, družbeni, zgodovinski, industrijski, itn.), le da v tej svoji primarni obliki (še) nimajo turističnega namena in funkcije.

Kušen (2000, 317) turistične vire razvršča v temeljne, neposredne in posredne. V drugo skupino (neposredni viri) uvršča turistične stavbe, naprave, agencije, informacije, promocijski material, kadre, stopnjo izobrazbe lokalnega prebivalstva, turistično organiziranost destinacije in sistem turističnega informiranja. V tretjo skupino (posredni viri) uvršča komunalno infrastrukturo, vsebine družbenega standarda, geografski položaj, prometno povezanost, dobro prostorsko organiziranost, estetsko oblikovane stavbe, ulice, trge, promenade, parke in podobno, mir v državi in njeno politično stabilnost. Avtor sklepa, da med emitivnim in (receptivnim) potencialnim turističnim prostorom, ki ima potencialne turistične privlačnosti, deluje privlačna moč, ki sili k vzpostavljanju njune medse- 
bojne komunikacije in $\mathrm{k}$ povečevanju receptivnih vsebin $\mathrm{v}$ potencialnem receptivnem prostoru.

Porter (1994, str. 447) meni, da je zelo pomembna in bistvena povezanost med aktivnostmi podjetja in njegovimi viri, ki imajo pravzaprav posredno vlogo. Ti izhajajo iz izvajanja aktivnosti v določenem času, lahko se jih pridobiva od zunaj ali pa gre za kombinacije obojega.

Ritchie in Crouch (1993, str. 36) izpostavljata razliko med ekonomsko izmenjavo dobrin in turizmom, $s$ posebnim poudarkom na pomenu primerjalnih in konkurenčnih prednosti za mednarodni turizem. Določena prečudovita dolina je v gospodarskem pomenu brez vsake vrednosti, če do nje ne pelje pot ali cesta, po kateri lahko pridejo turisti in obiskovalci. Brez dostopnosti predmet v turizmu nima vrednosti! Končni vrednost in uspešnost podjetja pa sta merljivi s številom kupcev, ki so pripravljeni plačati njegove proizvode in storitve. Podjetje je dobičkonosno, če ta vrednost presega skupne stroške vseh njegovih aktivnosti. Isto velja za turistično atrakcijo.

Kdor pride prvi, pridobi konkurenčne prednosti, saj po zaslugi prvenstva »pobira smetano «, zmanjšuje stroške $z$ dodatnim učenjem, utrjuje svoj zaščitni znak in vzpostavlja odnose $s$ kupci brez neposredne konkurence, dobiva najboljše distribucijske kanale in najboljšo lokacijo, najprimernejše surovinske in druge vire. Biti prvi omogoča preoblikovanje inovacije $\mathrm{v}$ prednost drugih oblik, ki pa imajo lahko trajnejšo veljavo. Inovacijo se lahko tudi posnema, vseh drugih dodatnih konkurenčnih prednosti pa največkrat ne (Porter, 1998).

$\mathrm{Na}$ splošno so moč ali posebne sposobnosti podjetja podlaga, ki mu omogoča pridobivanje konkurenčnih prednosti na trgu, medtem ko ga pomanjkljivosti omejujejo pri njegovih nalogah in dolgoročnih ciljih. Pojma »posebna sposobnost « ali »kritični dejavnik uspeha«, ki ju največkrat najdemo v literaturi, uporabljamo za oznako specifične kakovosti, ki podjetju omogoča edinstveno prilagajanje pri opravljanju njegovih nalog, in to bolje, kot zmorejo tekmeci (Olsen, Ching-Yick Tse in West, 1992, str. 24).

Huntova (2000, str. I40) opozarja na možnost izgube primerjalnih prednosti, ki se lahko zapravijo zaradi šibkosti ali splošne slabe izrabe posameznih notranjih dejavnikov v obliki:

I. neuspeha podjetja pri investicijah,

2. posledičnih dvomov in nejasnosti,

3. neuspeha v prilagajanju. 
V nadaljevanju opozarja tudi na možnosti preoblikovanja nekaterih virov v nevire, in sicer zaradi sprememb okusa potrošnikov in tržnih segmentov. Tudi spremembe, ki jih prinašajo patenti, zaščitni znaki, franšize in druge pravice, podjetju lahko uničijo primerjalne prednosti njegovih virov (Hunt, 2000, str. I 42).

Konkurenčne in primerjalne prednosti so na nek način minljive, saj se lahko pridobijo ali izgubijo zaradi različnih sprememb in vplivov iz zunanjega in notranjega okolja, zato jih podjetja skušajo ohranjati čim dlje. Trudijo se osredotočiti na tiste, ki so obstojnejše, da bi njihovi položaji na mednarodnem turističnem trgu ostali dolgoročni. Pravzaprav na trgu, ki se zaradi povpraševanja in ponudbe neprenehoma spreminja, lovijo ravnotežje.

Prašnikar in Debeljak (1998, str. 328) stalno konkurenčno prednost opredeljujeta kot konkurenčno prednost podjetja, ki je tekmeci ne morejo prevzeti oz. ogrožati. Ghemawat (v Prašnikar in Debeljak, I998) to pojasni: »Če hoče biti podjetje izjemno uspešno, mora biti boljše od tekmecev. Problem je v tem, ker je tudi konkurenca dobila isto sporočilo.«Kot stalna konkurenčna prednost se lahko opredeli tista, ki podjetju prinaša dolgoročne koristi.

Obstajajo določene zakonitosti, vezane na konkurenčno prednost na mednarodnem trgu (Porter, 1998, str. 579-583):

- Konkurenčne prednosti so dejansko posledica napredka, inovacij in sprememb (nekatere inovacije predstavljajo konkurenčno prednost, ko podjetje odkrije popolnoma nove kupce ali potrebe ali ko se usmeri na tržni segment, ki so ga tekmeci prej zanemarjali. Prednost se pridobiva, ker se mednarodna konkurenca počasi in neučinkovito odziva. Inovacije, ki prinašajo konkurenčne prednosti, velikokrat temeljijo na novih metodah ali tehnologijah, ki spreminjajo prejšnje vrednosti in zastarele procese).

- Konkurenčne prednosti zajemajo celovit sistem vrednosti; velikokrat kažejo na nove načine oblikovanja in vodenja celovitega sistema vrednosti. Pomen celovitega sistema vrednosti za konkurenčno prednost se kaže v prevladovanju grupiranja (clustering). Največjih konkurenčnih prednosti so največkrat deležne geografsko lokalizirane skupine (clusters).

- Konkurenčne prednosti so lahko stalne le ob nenehnem napredovanju in izboljševanju; prednosti, ki si jih podjetje pridobi, lahko obdrži le z nenehnim izboljševanjem, različnimi boljšimi načini opravljanja dela ter njihovo modifikacijo. 
- Konkurenčne prednosti zahtevajo nadgradnjo svojih virov; imeti stalno konkurenčno prednost za podjetje pomeni oviranje dela tekmecev, ki ga želijo posnemati. To pomeni, da mora podjetje neprenehoma dograjevati, dopolnjevati in izboljševati ideje, da bi tekmecem pustilo čim manj prostora.

- Stalna konkurenčna prednost zahteva globalni pristop k strategiji; podjetje konkurenčne prednosti na mednarodnem trgu ne more stalno ohranjati brez raziskovanja in širjenja svojih baz podatkov (home-base advantages) z globalnim pristopom $\mathrm{k}$ strategiji.

Če zakonitosti konkurenčne prednosti apliciramo na turistično destinacijo kot poslovni sistem, o čemer je pisalo več avtorjev (Poon, I993; Laws, 1995; Howie, 1996; Vodeb, 2014), lahko z gotovostjo trdimo, da tudi njena pomanjšana oblika (različica) - atrakcija deluje podobno. Torej, če na turistično atrakcijo gledamo kot na poslovni sistem, kar je glede na njene značilnosti, pogoje delovanja (Vodeb, 2014) in sistemsko strukturo (Leiper, 1990) kredibilno zagovarjati, je turistična atrakcija zaznamovana s svojimi konkurenčnimi prednostmi. Te so za njo kot njen DNK-zapis, nekaj, po čemer izstopa, je edinstvena, se razlikuje od drugih na turističnem trgu in je osnova njenega tržnega pozicioniranja, delovanja in obstoja. Če k temu pristopimo na tak način, vidimo, kako zelo pomembne so konkurenčne prednosti v primeru turističnih atrakcij, saj so vezane na njihovo bistvo, smisel in obstoj. Pa vendar, to spoznanje in zavedanje ni dovolj. V delovanju turistične atrakcije ga je potrebno zastopati na način, da se $s$ konkurenčno prednostjo atrakcije ukvarjamo, jo razvijamo in neprenehoma negujemo. Zavedanje, da je to proces, ki traja tako dolgo kot sama atrakcija, je izhodišče za dolgoročnost njenega delovanja. Ta se ne preneha $\mathrm{z}$ vzpostavitvijo atrakcije, $s$ prvim njenim pojavljanjem na turističnem trgu, tu se komaj začne.

Pri vsem tem pa ne gre izpustiti dejstva, da pri obravnavi konkurenčne prednosti glavno vlogo igrajo identiteta, specifične lastnosti in značilnosti dobrine oz. vira, ki je temelj komparativne prednosti. Ta je na podlagi sposobnosti menedžmenta turistično valorizirana in oblikovana $\mathrm{v}$ konkurenčno prednost, toda identiteta vira, $\mathrm{z}$ vsemi njegovimi lastnostmi, igra ključno vlogo v tem DNK-zapisu. Nenazadnje te lastnosti, skupaj z identiteto, atrakcija zrcali na destinacijo, po njej je ta prepoznavna in razločno jasna $\mathrm{v}$ primerjavi $\mathrm{z}$ drugimi destinacijami/atrakcijami in njihovimi primeri konkurenčnih prednosti. Da bi lahko celovito razvijali konkurenčne prednosti, ki so osnova našega delovanja atrakcije in/ali destinacije, je potrebno dodobra poznati identiteto, lastnosti in značilnosti lastnih komparativnih prednosti. Poznati in razumeti je treba njiho- 
ve najpodrobnejše, najfinejše detajle, zgodbo, zgodovino in razvoj. $S$ tem poznamo in razumemo njihov pomen $\mathrm{v}$ sedanjosti in ga lahko ponotranjimo, se poistovetimo z njim. Vse to izjemno pozitivno vpliva na gradnjo konkurenčne prednosti atrakcije, ker je na tak način vtkano v njeno najdrobnejšo in najfinejšo konstrukcijo. Bolj kot jo poznamo, razumemo, sprejemamo in živimo, bolj smo konkurenčni (uspešni) na turističnem trgu, ker jo dajemo na iskren in ljubeč način. V tem je bistvo uspeha v turizmu, saj gre za odnose in ljudi, ti pa prepoznajo vrednost in kakovost. Zato je potrebno zagotoviti in poskrbeti za gradnjo takega ljubečega odnosa do dobrin in virov, ki so nam na voljo, ta pa na podlagi poznavanja in sprejemanja identitete posameznikom in skupinam omogoča uspešno delovanje $\mathrm{v}$ turizmu. Tukaj govorimo že o izobrazbi ljudi, formalni in neformalni, doma in $\mathrm{v}$ institucijah, ki bi morale zagotoviti kakovostno znanje za uspeh v turizmu, pa tudi na drugih področjih. Zelo je pomembno, da se ta zavest krepi in neguje skozi vse ravni šolskega in družbenega sistema, od vrtca, osnovne šole in naprej, kajti v turizmu »zmagujejo « pristnost, raznovrstnost, bogastvo doživetij in kakovosten odnos.

\section{Definiranje pojma turistična atrakcija}

Turistična privlačnost je torej vitalni organ neke destinacije, najpomembnejši element turističnega proizvoda in glavni motivator za turistična potovanja in obiske (Zorko, 1999, Swarbrooke, 2002). Kretzschmar (2009) meni, da brez turističnih atrakcij ni turizma. Beerli in Martin (2004) pa menita, da so turistične privlačnosti sestavni deli destinacije, ki privlačijo turiste. McIntosh in Goeldner (1986) sta dejala, da je turistična privlačnost iniciator vsakega potovanja. Čomić in Kalmić (2007) pa sta prepričana, da je turistična privlačnost generator turističnih doživetij in spominov, ki še kako prispeva k oblikovanju podobe destinacije v vseh fazah turističnega potovanja. Gunn (1997) je nekoliko poetičen, ko pravi, da je turistična privlačnost življenjska moč turizma. Iz tega bi se dalo sklepati o pomenu turističnih atrakcij v turizmu nasploh, o njihovi ključni vlogi, saj predstavljajo njeno esenco, bistvo, okoli katerega se vrti vsaka turistična aktivnost. Lahko bi rekli, da turistične atrakcije in njihova učinkovitost determinirajo turizem in njegovo učinkovitost.

Turistična privlačnost je imenovan stalni vir, ki je pod nadzorom in se ga upravlja za uživanje, zabavo in izobraževanje obiskovalcev (Middleton, 1988). Tudi Pearce (199I) govori o imenovanem prostoru s posebnimi naravnimi in antropogenimi značilnostmi, ki je v središču pozornosti obiskovalcev in menedžmenta. Gunn in Var (2002) turistično privlačnost definirata kot prostor, na katerem je ponujena vrsta turističnih pro- 
izvodov in storitev za določen segment obiskovalcev. Harris in Howard (1996) menita, da gre v primeru turistične privlačnosti za fizične ali kulturne značilnosti na enem mestu, ki ga posamezni obiskovalci dojemajo kot sposobnega za zadovoljitev potreb v prostem času. Swarbrooke (2002) turistično privlačnost vidi kot imenovano mesto ali prostor s posebnimi človeškimi ali naravnimi značilnostmi, ki so v centru pozornosti obiskovalcev in menedžmenta. Prav tako Gunn in Var (2002) menita, da gre za razvite lokacije, ki so načrtovane in upravljane glede na turistove zanimanje, aktivnosti in veselje. Walsh-Heron in Stevens (1990) sta oblikovala razširjeno definicijo turistične privlačnosti, ki se glasi:

Turistična privlačnost je pojav na določenem območju, kraju ali središču aktivnosti, ki:

- je pripravljen za privabljanje tujih in domačih obiskovalcev ter se ga temu primerno upravlja;

- zagotavlja zabavo in vesela doživetja ter omogoča prijetno preživljanje prostega časa;

- je razvit z namenom realizacije svojega potenciala;

- se upravlja kot znamenitost, ki zagotavlja zadovoljstvo uporabnikom;

- zagotavlja primerno infrastrukturo in storitve, ki izpolnjujejo in zadovoljujejo povpraševanje, potrebe in interese obiskovalcev.

Pearce (1991) meni, da je turistična privlačnost določen predel s specifičnimi človeškimi ali naravnimi posebnostmi, ki so središče pozornosti turista in upravljavcev. Prav tako meni, da mora imeti privlačnost osupljiv ali/in nevsakdanji fizični oz. kulturni vir. Zagotavljati mora aktivnosti in doživetja obiskovalcev, ki spodbujajo domišljijo javnosti.

Swarbrooke (2002) meni, da turistične privlačnosti predstavljajo samostojne enote, posamezne predele ali točno določena manjša geografska območja, ki so dostopna in motivirajo veliko število ljudi, da prepotujejo določeno razdaljo od doma, navadno v prostem času, da jih za krajši, omejen čas obiščejo. Pri tem izključuje pojave, ki se jih ne da nadzorovati ali upravljati (npr. podnebje, klima ipd.). Iz zgornjih opredelitev izhaja, da je turistična atrakcija $v$ domeni menedžmenta in je njeno upravljanje nuja, saj so načrtovanje, vodenje, nadzor in organiziranje temeljne funkcije menedžmenta.

Vsekakor gre za kompleksnost pojma, za katerega je zaradi propulzivnosti področja težko poiskati univerzalno definicijo. Zaradi naraščajočih potreb in zahtev sodobnega turista namreč nenehno nastajajo nove oblike turističnih atrakcij, ki pa zaradi narave turističnih storitev čedalje bolj 
segajo tudi v sfero nematerialnega in neotipljivega. Zato ne čudi, da Austin (2002) ter Poria, Reichel in Brian (2006) menijo, da je turistična privlačnost izrazito družbeni fenomen, ki zahteva predvsem obravnavo vedenja potrošnikov (turistov, obiskovalcev). Prav tako pa Benckendorff in Pearce (2003) ter Timothy in Boyd (2006) opozarjajo, da ne smemo zanemariti organizacijskega vidika in menedžmenta turističnih privlačnosti. Tudi Sharpley (2009) namreč meni, da turistične privlačnosti niso zgolj razlog za potovanje turistov, pač pa predstavljajo fokus turistične aktivnosti, generirajo prihodek, delovna mesta ter širši regionalni razvoj destinacije in regije.

Kruczek (20II) atrakcije definira kot konstitutivni element turističnega proizvoda, imenovan edinstvena privlačnost, ki ima moč privabiti obiskovalce, da obiščejo neko območje ali destinacijo. V kombinaciji s turističnimi storitvami atrakcije sestavljajo turistični proizvod. Mill in Morrison (2002) atrakcijo definirata kot vse, kar ima moč privlačiti obiskovalce.

Definiranje turistične atrakcije je zaradi kompleksnosti in njenih specifičnih značilnosti dokaj težavno. Ne obstaja univerzalna, splošno sprejeta, mednarodno prepoznavna definicija turističnih atrakcij, predvsem zaradi mnogoterih vrst in obsega področja, ki ga atrakcije zajemajo. Prav tako pa je definiranje težavno zaradi nenehne dinamike na tem področju in zanj značilne večplastnosti. Pa vendarle je definiranje pomembno in potrebno zaradi lažje obravnave, primerjav, statističnega spremljanja in razumevanja, kar nedvomno vpliva na uspešnost upravljanja in načrtovanja turističnih atrakcij. Iz zgornjih navedb lahko sklepamo, kakšni so skupni vzorci poskusov definiranja posameznih avtorjev, in ti so:

- imenovanost vira oz. atrakcije ( $\gg$ nomen est omen«, kar pomeni »ime je znamenje« ali ime ima pomen; verjetno od tod tudi naša sintagma $\gg$ znamenitost $\ll$ ),

- značilnosti zanimive za obiskovalce (tisto, kar vzbuja interes in predstavlja motiv obiska),

- načrtovanje in upravljanje (potreba po menedžmentu) in

- povezanost s turističnim proizvodom/destinacijo (sestavljenost, sistemskost, mozaik).

Imenovanost vira oz. atrakcije je ključnega pomena, saj jo zaznamuje, opredeljuje in določa. Značilnosti ali lastnosti predstavljajo nabor trajnih karakteristik vira, njegovih atributov, vsega tistega, kar je njemu lastno, $s$ čimer se ga lahko opiše in opredeli. Prav te značilnosti so tiste, ki pri obiskovalcih vzbujajo interes po obisku, zato je zanesljivo pomembno pozna- 
vanje le-teh, razumevanje in njihova ustrezna interpretacija v luči atrakcije. Upravljanje je zagotovilo delovanja in obstoja vsega, kar človek pozna in razume. Viri sami po sebi (denimo naravni) niso upravljani, se jim pa z namenom in uporabnostjo za človeka doda neka vrednost, s čimer se zagotovi učinkovitost uporabnosti za namen, ki je določen. Tako v turizmu iz vira nastane privlačnost oz. iz komparativne prednosti konkurenčna. Sposobnost upravljanja torej določa učinkovitost in dolgoročnost atrakcije. Povezanost vira oz. atrakcije z drugimi storitvami, infrastrukturo, zmogljivostmi in s proizvodi je $\mathrm{v}$ turizmu bistvenega pomena, zato pa se sistemska teorija tako logično prepoznava in aplicira na primeru turizma nasploh. Sestavljenost in integracija različnih elementov v turistični ponudbi predstavljata zahtevo in pogoj za zadovoljitev pričakovanj sodobnega turista, saj je povpraševanje heterogeno. Vsi ti elementi, uporabljeni pri definiranju, nakazujejo na naravo turističnih virov in atrakcij, ki je skladna z naravo turizma kot družbenega, gospodarskega in prostorskega fenomena.

K definiranju atrakcij torej lahko pristopimo na več različnih načinov, a ko opazujemo različne pristope pri definiranju, lahko sklenemo, da je to možno $\mathrm{z}$ več vidikov, pretežno pa sta $\mathrm{v}$ uporabi organizacijski in izkustveni vidik (ali vidik obiskovalca) definiranja atrakcij. Organizacijski vidik izhaja iz ponudbe turističnih atrakcij, izkustveni (ali vidik obiskovalca) pa iz povpraševanja po njih.

Organizacijski vidik definiranja temelji na razvoju atrakcij, ki pa je posledica človekovih (menedžmentovih) organizacijskih sposobnosti in veščin. Torej, gre za človeški poseg v procesu načrtovanja razvoja atrakcije, kar potrjuje dejstvo potrebe in pomena takega človekovega poseganja. Eno izmed prvih definicij turistične atrakcije je podal Jeffries (I97I), ki je ravno ob njej »izpostavil« pomen upravljanja ter transformacije turističnega vira, ki ga on imenuje »surovina«; pravi, da je na slednji treba delati, da jo valoriziramo v turistično atrakcijo, ta pa je namenjena točno določenemu ciljnemu segmentu in zagotavlja turistično izkušnjo, česar surovina t ne more. Njegova definicija govori o tem, da različne destinacije ponujajo pokrajino, plaže, dediščino, toda te imamo lahko za surov material, dokler jih ne pričnemo razvijati v smeri povpraševanja in zahtev potencialnih obiskovalcev. Jeffries o atrakciji razmišlja kot o turističnem proizvodu, ta pa ima turistični namen - zadovoljuje namreč turistične potrebe in pričakovanja.

MacCannell (1976) turistično atrakcijo definira kot sistem, sestavljen iz turista, mesta, ki je vredno obiska, in zaznamovalca. Avtor $s$ to sistemsko strukturo opozarja na medsebojno pogojenost in kompleksnost atrak- 
cije kot fenomena. Prav tako pa tudi na dejstvo, da ni le atrakcija sama po sebi dovolj - potrebna je informacija, ki kaže na pomen, vrednost in smisel obiska. Avtor kot prvi uvaja koncept zaznamovalca, katerga glavni namen je informirati obiskovalca o atrakciji. O sistemski strukturi turistične atrakcije bomo podrobneje pisali v nadaljnjih poglavjih.

Lew (1987) atrakcije definira kot vse tiste elemente izven vsakdanjega okolja obiskovalcev, ki slednje privlačijo, da jih obiščejo. Ti elementi so ponavadi pokrajina, aktivnosti in doživetja. V prvi različici (pokrajina) je vloga obiskovalca pasivna, v drugi (aktivnosti) aktivna, saj gre za njegovo udeležbo pri nekakšni aktivnosti, pri tretji (doživetja) pa je lahko tudi proaktivna, saj poleg zunanjih dejavnikov velik delež tega doživetja kreira njegov notranji svet (vrednote, kulturno ozadje, motivi, pretekle izkušnje, preference, okus ...).

Gunn (1988) v svoji definiciji prav tako opozarja na pomen načrtovanja in organizacije, saj podobno MacCannellovi definiciji tudi on vidi atrakcijo skozi strukturo treh elementov (pri njemu gre za jedro, zunanji obroč, zaprto območje (ang. nucleus, inviolate belt, zone of closure)), ki pa pravzaprav pričajo o potrebi, da se atrakcijo načrtuje in organizira v skladu s potrebami ciljnega trga. Isti avtor prav tako nadgradi svoj organizacijski pristop $\mathrm{k}$ definiranju atrakcije $\mathrm{z}$ definicijo, kjer atrakcije pojmuje kot $\gg$ razvite lokacije, ki so načrtovane in upravljane $\mathrm{z}$ namenom zadovoljiti interese obiskovalcev«. Gunn (1988) meni, da lahko destinacija razpolaga s številnimi viri, toda ti ne delujejo kot atrakcija, vse dokler niso organizirani in upravljani na način, da sprejmejo obiskovalce. Ta receptivna funkcija atrakcij je torej ključna za njihovo delovanje, zahteva pa poseganje človeka (menedžmenta).

Middleton (1988) atrakcije definira kot označen trajni vir, ki ga nadzoruje menedžment, zadovoljstva, zabave ali izobraževanja obiskovalcev. Tudi ta definicija ključno vlogo pripisuje upravljanju atrakcije. Leiper (1990), podobno MacCannellu in Gunnu, atrakcijo definira s sistemskega vidika in meni, da je ta sistem sestavljen iz turista, jedra in zaznamovalca. Sistem je vzpostavljen le pod pogojem, da so vsi trije elementi medsebojno povezani. Povezanost teh treh elementov je zagotovljena z organiziranostjo (menedžmentom). Podobno kot pri MacCannellu ima zaznamovalec funkcijo informiranja obiskovalca, jedro pa je, tako kot pri Gunnu, ključni element interesa (motiva) za obiskovalca.

Tudi Pearce (199I) atrakcijo definira kot imenovan kraj s specifičnimi človeškimi ali naravnimi značilnostmi, ki pa so središče interesa obiskovalcev in menedžmenta. Človeška prisotnost in aktivnost oz. poseganje je v tej definiciji več kot očitno, torej je človeški dejavnik vseprisoten 
in nenadomestljiv, saj ga imamo na strani ponudbe in prav tako na strani povpraševanja.

Mill in Morrison (2002) opozarjata na potrebo po organizacijski intervenciji s strani menedžmenta, da bi do konzumacije in zadovoljstva turista (obiskovalca) sploh lahko prišlo. Avtorja v definiranju atrakcije omenjata pomen tudi drugih potrebnih storitev, prevoza in gostinstva, ki pripomorejo k zadovoljstvu obiskovalca in naredijo to izkušnjo celovitejšo. Ta večplastnost in povezanost drugih proizvodov in storitev (tudi infrastrukture) je v nekem osnovnem kontekstu prisotna že v Gunnovi definiciji oz. strukturi atrakcije (jedro, zunanji obroč, zaprto območje). O tej povezanosti atrakcije s sorodnimi in povezljivimi storitvami in proizvodi, $\mathrm{z}$ elementi ponudbe in drugimi koncepti bo govora $\mathrm{v}$ nadaljnjih poglavjih.

Izkustveni vidik definiranja ali vidik obiskovalca je tisti, ki se osredotoča na vsebino atrakcije oz. izkustvo o tej atrakciji z vidika obiskovalca. Avtorji, ki pri svojih definicijah izhajajo s tega vidika definiranja, so številni. Med drugimi Boorstin (2012), ki pravi, da gre za izkustvo o drugi kulturi (v tem primeru je to atrakcija), prav tako pa meni, da so turisti (obiskovalci) neobčutljivi na pristnost atrakcij, kar pa je že del kritične teorije turizma, katere glavni nosilec je ravno Daniel Boorstin. Cooper, Fletcher, Gilbert in Wanhill (1993) atrakcije povezujejo z rekreacijskimi in izobraževalnimi aktivnostmi za obiskovalce. Te aktivnosti so po njihovem prepričanju nosilci turističnih izkušenj ali doživetij za obiskovalca. Najširši v tem vidiku definiranja je najbrž Holloway (1994), ko pravi, da je atrakcija vse tisto, kar privlači pozornost obiskovalcev, da dejansko pride do obiska. On se prav tako navezuje na ostale pomembne in povezljive storitve, ki tvorijo celovitost turistične izkušnje. Pomembnejše pa je njegovo prepričanje, da gre v primeru atrakcij za interakcijo obiskovalca z virom in ne zgolj za kreacijo izkušnje obiskovalca. Tukaj je izpostavljeno zavedanje, da pri oblikovanju turistične izkušnje ne nastopajo zgolj zunanji in objektivni dejavniki, pač pa docela obiskovalčev notranji, subjektivni svet. Torej ima menedžment nalogo in odgovornost na podlagi zunanjih dejavnikov in tistih, na katere ima lahko vpliv, oblikovati pogoje za turistično izkušnjo. Notranji »svet« oz. subjektivno doživetje vsakega posameznika pa je odvisno le od njega samega. Nanj imajo zunanji dejavniki lahko samo omejen učinek (marketing, mediji ...), zato se, zaradi procesa interakcije, ki se zgodi na podlagi teh zunanjih vplivov in notranjih stanj posameznika, $v$ zadnjih treh desetletjih stroka tako zelo poglablja v menedžment turističnih atrakcij. Vsem je skupno iskanje načina, kako vplivati na posameznika in njegova doživetja. Predvsem pa se kaže potreba po razumevanju tega vpliva skozi interakcijo med zunanjimi in notranjimi dejavniki v sistemu turistične atrakcije. 



\section{Koncept turistične atrakcije}

Glede na dejstvo, da je turistična atrakcija osrednji del turističnega procesa in njegovega ekonomskega učinka skozi turistično potrošnjo, je nedvomno pomembno poglobljeno razumevanje koncepta atrakcije.

Osnovo za razumevanje tega koncepta najdemo v teorijah MacCannella (1976) v njegovi semantični analizi atrakcij in Leiperja (1990) v njegovem sistemu turističnih atrakcij. Prav tako se pri obravnavi koncepta turistične atrakcije primarno opiramo na Boorstinovo kritično teorijo turizma (2012) in Veblenovo teorijo brezdelnega razreda (ang. leisure class) (2009), ki v osnovi osvetljuje družbeno plat potrošnje in potrošnjo dobrin opredeljuje kot znak socialnega statusa.

\section{Razumevanje koncepta turistične atrakcije $\mathrm{z}$ vidika družbenega konteksta in kritične teorije turizma}

Gunn (1988) je mnenja, da so imele atrakcije od nekdaj magnetno oz. privlačno moč nad obiskovalci, nasprotno pa je Boorstin (2012) mnenja, da je koncept turistične atrakcije razmeroma moderen konstrukt in ga kronološko postavi v drugo polovico 19. stoletja. Torej, pojav pojma turistična atrakcija sovpada s pojavom delavskega razreda, ki je rezultat industrijske revolucije. Pred industrializacijo, v času fevdalne družbene ureditve, namreč delavskega razreda ni bilo. $Z$ industrijsko revolucijo, ki je bila spočeta predvsem s tehnološkim razvojem, prvimi tovarnami, ki so zaposlovale zelo veliko število ljudi, in z urbanizacijo, je nastal delavski razred. Način življenja in dela se je korenito spremenil in to je bil začetek nove dobe. Delavski razred so sestavljali delavci, zaposleni v novih tovarnah 
v mestih, ki pa so še nedolgo nazaj prišli s podeželja (proces urbanizacije). Nove priložnosti in tehnološko-gospodarske razmere so vplivale na družbene spremembe. $Z$ urbanizacijo so se spremenili družinska struktura, način življenja in dela, $s$ tem pa tudi način preživljanja prostega časa. Pojmovanje časa je sploh večplastno pomenljiv koncept, $s$ pomočjo katerega lahko razložimo prehod iz agrarne $\mathrm{v}$ industrijsko dobo. O tem podrobno razpravljata Bramham in Wagg (20I4), ko v grobem razdelita čas na obdobje pred in po industrializaciji. Pred industrializacijo je človek živel v skladu z naravnimi zakoni (dnevna opravila, nočna opravila, opravila v skladu z letnimi časi, vremenskimi razmerami itn.), od industrializacije dalje pa je čas dobil povsem druge dimenzije. Delo v tovarni je bilo namreč odvisno od drugih pogojev (stroji, tekoči trak, delovne razmere, odnos delodajalca, zahteva po večanju produktivnosti, stroški itn.). Prav tako je bilo življenje $\mathrm{v}$ mestu povsem drugačno od tistega na podeželju. Vse to so izhodišča za razumevanje potovanja posameznika v novi luči družbenih in gospodarskih sprememb. Predvsem pa se potovanje z obdobjem industrializacije demokratizira oz. postaja dostopnejše širšemu krogu ljudi. Prav demokratizacija potovanja je osnova za Boorstinovo kritiko turizma, ki jo poskušamo orisati v nadaljevanju.

Boorstin (2012) problematizira plehkost turistične izkušnje in turistične atrakcije kot objekta te izkušnje. Sprememba oz. potreba po nevsakdanjem in neznanem, ki je eden ključnih motivov turističnega potovanja, je stalnica in se ne spreminja s časom. Spreminjata pa se način doživljanja in sprejemljivost tega doživljanja v obliki zahtev ter potreb turistov. Pustolovščina, ki naj bi jo potujoči iskal na svoji poti, je izrabljena in razredčena izkušnja, ki jo ublagovlja menedžment in sprejemajo turisti, ker na pravo pustolovščino dejansko niso pripravljeni. Boorstin navaja Descartesa, ki je v zgodnjem 17. stoletju zapisal, da je potovanje skoraj kot pogovor z ljudmi iz preteklosti. Odpiralo naj bi obzorja, širilo svobodo uma in razumevanje tega sveta. Tukaj so mišljena predvsem miroljubna potovanja, potovanja $\mathrm{z}$ namenom odkrivanja in raziskovanja drugih kultur. $V$ tem smislu o potovanju govori spoštljivo in nadvse etično kot o gonilni sili razvoja in spremembi človeštva in družbe, saj naj bi bila renesansa posledica odpiranja oči, spoznavanja sveta z odkritjem Amerike in potovanji okrog zemlejske oble, razsvetljenstvo pa ravno tako spodbujeno s potovanji iz Evrope na zahod in vzhod. O potovanju torej govori kot o univerzalnem katalizatorju. Meni, da so potovanja ljudi zaslužna za spremembe $v$ razmišljanju in čutenju človeka. Toda, potovanje naj bi bilo nekaj res velikega in dragocenega. Potovati nekoč je pomenilo postati svetovljan, kulturen, razgledan, se razviti, odrasti. Potovanje je bilo del 
splošne kulture, izobrazbe in je zahtevalo trud, vznemirjenje, odrekanje, pogum in napor. Šlo je za določeno tveganje, prilagajanje lokalnim razmeram, potnik je moral biti aktiven.

Zanimiva je Boorstinova (2OI2) etimološka razlaga besede travel (potovanje), ki naj bi v osnovi prihajala iz francoske besede travail, ta pa pomeni delo, težave ali celo mučenje, nedtem ko izraz tourist (turist) pomeni osebo, ki potuje iz zadovoljstva in zabave. Gre namreč za krožno potovanje (tour - sklenjen krog), kot naj bi ga poznali v klasičnem turiz$\mathrm{mu}, \mathrm{ki}$ pomeni potovanje iz izhodišča (vsakdanje okolje, dom) proti cilju (nevsakdanje okolje, sprememba, eksotika, drugačnost). Po določenem času se oseba vrne v izhodišče, kar jo loči od nomada, ki pa na potovanju ni časovno omejen in se ne vrača v izhodišče. Torej je bilo pravo prvo potovanje pustolovščina, ker je bilo dostopno le redkim (glede na družbeni status) in redki so se upali na potovanje, ker pri tem ni šlo za udobje in varnost - ravno nasprotno: na poti so prežale različne nevarnosti in negotovosti in vseskozi je šlo za aktivno izkušnjo (učenja, prilagajanja, spoznavanja drugačnosti). Dostopnost (cenovna in fizična) in številčnost potovanj je degradirala pristnost potovalne izkušnje in pustolovščina je bila zamenjana za neko instant izkušnjo, umetno ustvarjeno, ublagovljeno za prodajo, za denar, ki ga turist plača, ko kupi turistični aranžma. Pri tem si želi udobje svojega doma, varnost in komoditeto, brez najmanjšega tveganja. Paradoksalno pa je, da pričakuje senzacijo v doživetju, ki pa dejansko to ni več, toda turist pristaja na zaigranost ali pridih resničnega, saj ga bolj kot pristnost prepriča kvantiteta videnega in doživetega.

Thomas Cook (Boorstin, 20I2), kot prvi podjetnik s področja turizma, se je branil podobne kritike svojih sodobnikov, češ da gre za snobizem, saj naj bi bilo potovanje dostopno množicam in ne rezervirano zgolj za izbrane. Cook je zagovarjal številni delavski razred iz etičnih in humanističnih vzgibov ali pa je v množici ljudi, ki jim je prodajal potovanja, videl podjetniško priložnost. Odgovor na tozadevno vprašanje presega namen našega dela.

Boorstin (20I2) je nedvomno prepričan, da ko potovanje postane varno in dostopno (fizično in finančno), potnik postane turist in umetnost potovanja postane turizem. Ni tveganja, ni vznemirjenja, ni napora, ni aktivnosti, ni izkušnje ... tistega, kar dejansko iščemo od potovanja. Boorstin kot oster kritik turizma tako problematizira turistične atrakcije, češ da ponujajo nepristne posredne izkušnje, umetne izdelke, ki jih je treba konzumirati na mestu samem, medtem ko je »prava stvar « (original) prosto dostopna kot zrak, ki ga dihamo. V tem pravzaprav vidimo direktno kritiko potrošništva, ki svoje korenine vleče iz obdobja množičnega 
turizma, ko je Boorstin deloval. Tako avtor meni, da je moderni turizem posledica demokratizacije in da so raritete, dragocenosti in vrednosti vzete iz konteksta ter približane množici, ta pa teh vrednosti niti ne razume niti ne vidi in jih zgolj površno opazuje, ker so pač na pladnju (oz. v njihovem zakupljenem potovalnem aranžmaju). Po njegovem gre za odtujitev od originala in njegovega naravnega okolja (konteksta), kot za živali v živalskem vrtu.

Turistične destinacije ali mesta imenuje »turistične Meke« in te, meni, nekultivirani publiki ponujajo zgolj ponaredke za denar. Pravi, da so Svetovne razstave s tem, ko so postale atrakcija, dobile umetni značaj. Po njegovem naj bi bile atrakcije najslabša podoba nacionalne kulture, ki naj sploh ne bi imela pomena za domačine in je njen pomen umetno ustvarjen za turiste, saj naj bi bila »prodajni hit za turistično blago « (Boorstin, 2012, str. 103), predstavljale naj bi turistični oder, kjer je vse zaigrano. $S$ tem, ko si je množica pripadnikov delavskega razreda potovanja Grand Tour začela prilagajati svojim omejenim življenjskim standardom in izobrazbi, sta se vrednost in dragocenost potovalne izkušnje začeli razblinjati. Boorstin tako meni, da ima turist le redko željo po pristni kulturi (saj jo redko razume), raje ostaja pri svojih ustaljenih,, ozkih pričakovanjih. Demokratizacija potovanja (nižanje stroškov, naraščanje organiziranosti in izboljšave $\mathrm{v}$ transportu) je pripomogla $\mathrm{k}$ redčenju potovalne izkušnje oz. tistega, kar slednja v osnovi je - pustolovščina. Tako potovanje ima za atavistično in atrakcije razume kot vabo oz. past za nevedne turiste. Izboljšani transportni pogoji in tehnologija, meni Boorstin, človeka oropajo pristne izkušnje premikanja v prostoru, kar naj bi turizem bil. Prav tako moderni turizem onemogoča spoznavanje novih ljudi. Sprašuje se, kako bo nadaljnji napredek v tehnologiji vplival na redčenje potovalne izkušnje. (Kaj bi rekel za sodobna virtualna potovanja?) Kritičen je do instantnega potovanja, saj je prostor z modernim potovanjem izgubil vlogo; prostora med potovanjem dejansko niti ne zaznamo, saj se prevažamo s superzmogljivimi letali in drugimi prevoznimi sredstvi, ki neverjetno skrajšajo čas potovanja in že v naslednjem hipu smo na drugem koncu sveta, ne da bi ob tem kaj videli ali doživeli. To je za avtorja problematično, saj meni, da hitrost potovanja posameznika prikrajša za občutek spremembe prostora, njegovih značilnosti in vrednot. Tako je prikrajšan za vse, kar je na poti do cilja tega potovanja, in ne doživlja dejanskega potovanja, temveč samo njegovo končno postajo. Doživetje posameznika se $s$ hipno spremembo prostora ne gradira, ne razvija in postopoma oblikuje. Sprememba prostora nastopi trenutno, zahvaljujoč tehnologiji transporta. $Z$ druge strani pa to ni problematično $\mathrm{z}$ vidi- 
ka dostopnosti potovanja in udobja posameznika, saj je to slednjega velika prednost, ko je omejen s časom. Ob predpostavki, da sodobni človek zelo veliko potuje in ima zelo malo časa, je sodobna potovalna tehnologija v veliko pomoč.

Boorstin (2012) resnično verjame, da je umetnost potovanja izrinil turizem, ki je dostopen množicam, da je sprememba, ki je osnova motiva za potovanje, izgubljena, saj je prostor kot dimenzija $\mathrm{v}$ tem premiku postal irelevanten. Potemtakem je potovalna izkušnja izgubila svojo esenco vznemirjenost, neznano, nepričakovano, spontano. Namesto da stopimo korak naprej in se zazremo skozi okno, da vidimo, kaj je onkraj, gledamo le $\mathrm{v}$ zrcalo in vidimo samega sebe in svoj vsakdan.

Tudi Richards (2002) pod vplivom Boorstinovega koncepta atrakcije slednjo razume kot ne preveč družbeno vredno obliko kulture, z nizko notranjo vrednostjo, ki je le prodajna uspešnica za zadovoljitev turistove komoditete. Sam pravi, da je čas potrdil Boorstinovo teorijo (ta je svojo kritiko turizma objavil sredi 6o-ih let prejšnjega stoletja), čeprav so mu mnogi avtorji oporekali glede nizke kulturne in družbene vrednosti atrakcij. MacCannell je tako menil, da atrakcije dajejo pomen obstoju novega brezdelnega razreda (turistom). Tako definira atrakcijo kot izkušnjo, ki nastane $\mathrm{v}$ interakciji med turistom, znamenitostjo in markerjem (MacCannell, 1976). MacCannellova semantična analiza atrakcije postavlja v okvir postmoderne ekonomije simbolov, kjer je pomen njihove označevalne vloge in družbene potrošnje znatno večji kot sam kraj aktivnosti. $O$ tem bo podrobneje govora $\mathrm{v}$ naslednjem poglavju, ko bomo obravnavali sistem turistične atrakcije.

Če gremo korak nazaj, na turistovo perspektivo doživljanja atrakcije, ki jo je Boorstin tako ostro kritiziral, lahko izpostavimo drug fenomen, to pa je neizrazita tipologija sodobnega turista, o kateri poročata Weiermair in Peters (2000), saj ugotavljata, da je izginil tipični potrošnik, ki se značilno vede ne glede na ceno in kakovost turističnega proizvoda. Sodobni turist po njunem mnenju reagira predvsem na notranje dejavnike motivacije in ne na zunanje. Omenjata t. i. novo staro etiko v potrošnikovem vedenju. Ta naj bi temeljila na dejstvu, da sta zadovoljstvo in poživitev za potrošnika pred funkcionalnim in koristnim (Weiermair in Peters, 2000, str. 24). Uspešnost turistične atrakcije se po njunem mnenju meri z uskladitvijo treh ključnih elementov. To so domišljija, privlačnost in dovršenost. Pravilno odzivanje menedžmenta na potrebe in zahteve sodobnega potrošnika (turista), ki so v osnovi mešanica potrebe po soncu, udobju, drugačnosti in pustolovščini, miru in naravi kot tudi poživitvi in zabavi, je zmagovalna formula. Za menedžment turističnih atrakcij me- 
nita, da je njegova ključna spretnost demistifikacija tradicionalnega razumevanja kulture, da bi lahko pritegnil širšo publiko, oz. atrakcijo naredil dostopno za množice, kar je cilj ekonomije obsega. Ravno to je tisto, kar Boorstin označuje za uničenje umetnosti potovanja. V sodobnem turizmu gre za zelo natančno načrtovan, premišljen in uigran scenarij, kjer nič ni prepuščeno naključju (20I2, str. 27) in je za uspeh potrebno natančno razumevanje medsebojne interakcije ter odnosov med potovalnimi motivi, kompleksnim procesom storitev in turistične atrakcije.

\section{Leisure class - brezdelni razred}

Pojem leisure class (brezdelni razred), ki ga uvaja ameriški ekonomist in sociolog Thorstein Veblen v svojem znamenitem delu The theory of leisure class iz leta $\mathrm{I} 899$, prvotno razumemo kot družbeni razred ljudi, ki jim ni treba delati in se posvečajo predvsem brezdelju ter razkazovanju svojega bogastva, s čimer dejansko potrjujejo (označujejo) svoj družbeni status. Leisure (prosti čas) je tukaj obravnavan kot nasprotje dela, kar je še danes razmeroma aktualno pri obravnavi teh dveh konceptov. Avtor prosti čas (leisure) definira kot neproduktivno preživljanje prostega časa. Toda z industrijsko revolucijo se družbene razmere bistveno spremenijo, saj se kot produkt industrijske družbe ustvari nov družbeni razred - delavski razred. Ključno pri tem pa je, da se potrošnja iz višjega sloja razširi med navadne delavce; pred tem je bila sredstvo označevanja družbenega statusa. Veblenova teorija razkazovalne potrošnje govori o tem, da so ljudje iz nižjega družbenega razreda začeli posnemati življenjski slog in znotraj tega tudi potrošniško vedenje višjih slojev. $\mathrm{Na}$ ta način so se distancirali od nižjih slojev. Pred industrijsko revolucijo je bil prosti čas dokaz bogastva. Veblen meni, da se z množičnostjo delavskega razreda povečuje tudi množičnost potrošnje ter da je potrošnja način komunikacije, skozi katerega se sporazumevajo pripadniki družbenih razredov. Podobno kot Boorstin Veblen govori o razblinjanju ekskluzivne pravice do potrošnje višjega razreda in prehajanju te pravice in praks na nižji, množičnejši razred.

Sociolog Pierre Bourdieu za razliko od Veblena meni, da za družbeni razred pomembno vlogo odigra kulturni in ne zgolj ekonomski kapital. Bourdieu (2010/1986) z opredelitvijo kulturnega kapitala opozarja na pomembno povezavo med posameznikovim družbenim razredom, kulturo in izobraževanjem. $S$ svojo raziskavo konec 70-ih let dokaže, da so med družbenimi razredi pomembne kulturne razlike, predvsem izobrazba, ki naj bi imela odločilni vpliv na vzorec potrošnje, okus in izbiro posameznika v potrošnji (Bulc, 2004). 
Če povežemo vse omenjene koncepte in teorije, lahko sklenemo, da sta pravica in potreba do preživljanja prostega časa, skupaj s prevladujoči$\mathrm{mi}$ in z značilnimi vzorci, demokratizacijo in dostopnostjo potovanj ter drugih oblik potrošnje, prešli od višjega, manj številčnega družbenega razreda na nižji, številčno veliko obsežnejši (delavski) razred. Razlika med enimi in drugimi ni več zgolj v dejanskem razpolaganju z materialnimi dobrinami ali sredstvi - seveda so ostale precejšnje razlike v količini in viru teh sredstev, so pa lahko izrazite razlike med temi družbenimi razredi pretežno v kulturnih in družbenih praksah, vrednostnemu siste$\mathrm{mu}$, izobrazbi, okusih, navadah, vzgoji in vedenju. Lahko bi rekli, da so te razlike nemara posledica različnih ekonomskih oz. materialnih izhodišč posameznika, zato je o tem nehvaležno soditi in posploševati. V kritičnih teorijah turizma namreč razberemo sporočilo, da potovanje izgublja epitet umetnosti, vzvišenosti, raritete in luksuza, saj ga množičnost in konzumacija »novih « potrošnikov okrade teh lastnosti.

$S$ pojavom industrijske revolucije, delavskega razreda in demokratizacije potovanja se načeloma pojavi tudi koncept turistične atrakcije, ki ga $z$ enakim tonom obravnavajo in razlagajo kritiki turizma. Torej ima turistična atrakcija enak predznak in slabšalni pomen kot turizem, saj je njegova esenca. 



\section{Sistem turistične atrakcije}

Sistem turistične atrakcije je v okviru sistemske teorije postavljen v širši turistični sistem kot njegov podsistem. Sistemski vidik obravnave turizma temelji na sistemski teoriji, ki se razvija od druge polovice 20. stoletja, temelji pa na prepričanju, da lahko turizem kot pojav razumemo na podlagi njegovih posameznih delov, povezav med njimi in interakcije znotraj sistema. Zagovorniki sistemskega pristopa v turizmu so Mill in Morrison (1985), Donald Getz (1986), Richard McIntosh in Charles Goeldner (1986), Jafar Jafari (1987), Neil Leiper (1990), Erick Laws (1995) in drugi. Sistemski vidik turizma, destinacije in atrakcije, torej od makro do mikro ravni, je v pomoč pri razumevanju in upravljanju, doseganju višje stopnje organizacije in učinkovitosti v turizmu.

MacCannell (1976) atrakcijo vidi kot del širšega turističnega sistema, ki ni v izolaciji. Leiper (1990) pa je nadgradil to misel, opirajoč se na sistemsko teorijo, in preformuliral MacCannellovo definicijo. Turistična atrakcija je po njegovem sistem, ki ga sestavlja povezava treh elementov:

I. turista,

2. znamenitosti in

3. zaznamovalca.

Atrakcija je vzpostavljena, ko so vsi trije elementi sistema povezani. Ta definicija predvideva konzumacijo atrakcije z ogledom (obiskom ali doživetjem), ki pa ne zahteva nujno prisotnosti značilne znamenitosti. S tem želi povedati, da atrakcija ni nujno vezana na fizični prostor, ki razpolaga z neko znamenitostjo. O tem je bilo govora v predhodnem poglavju, kjer smo pojasnili, da gre lahko pri atrakciji za prostor, pojav, osebo ali 
drugo obliko atrakcije. Zato Leiper oblikuje splošnejši model atrakcije in znamenitost preimenuje $\mathrm{v}$ jedro ter pravi da je atrakcija sistem, $\mathrm{v}$ katerem deluje povezava treh elementov:

I. turist (človeški element),

2. jedro (ključni element privlačnosti) in

3. zaznamovalec (informativni element).

\section{Leiperjev sistem turističnih atrakcij}

V sistemu atrakcije je torej najpomembnejša povezava treh elementov (turist, jedro in zaznamovalec), saj brez nje sistema ni oz. ne deluje.

Človeški element je v turizmu zmeraj prisoten, saj brez njega ni turizma, ne na strani povpraševanja (v primeru, ki ga obravnavamo tu, torej turist) ne na strani ponudbe (turistično gospodarstvo, turistična ponudba, destinacija, atrakcija). Človeški dejavnik ima hkrati v tem sistemu izjemno dinamične lastnosti, saj se ves čas spreminja (okusi, pričakovanja, potrebe, vedenje turistov), in pa statične lastnosti (turistično bivanje - začasno bivanje na turističnem potovanju ali obisku turistične atrakcije). Turist je potrošnik - skozi turistično potrošnjo se izkazuje in udejanja turistična ekonomska funkcija, toda v turizmu ne gre zgolj za ekonomsko funkcijo ali pojav. Turizem je tudi družbeno-kulturni pojav in prostorski fenomen, saj se dogaja v nekem prostoru (družbeno-kulturnem in naravnem). Glede na prostor gre $\mathrm{v}$ turizmu zmeraj za krožno potovanje iz izhodišča (domicila turista) do cilja (destinacije ali atrakcije same). Vmes med tema dvema poloma pa je prehodni ali tranzitni prostor. $V$ vseh teh točkah je prostor konstantna in pomembna dimenzija $\mathrm{v}$ turističnem doživetju kakor tudi turistični ponudbi.

Prav tako jedro ali ključni element privlačnosti predstavlja glavni motiv, ki spodbudi obisk atrakcije. Botti, Peypoch in Solonandrasana (2008) menijo, da je treba jedro atrakcije razumeti glede na čas, ki mu ga turist namenja s svojim obiskom. Ta odnos, ki se vzpostavi med turistom in jedrom atrakcije, je izjemno subjektiven. Čas, ki ga turist namenja obisku atrakcije, je v tem smislu ključna dimenzija pri klasifikaciji atrakcij. Pri tem pa Leiper (1990) govori o naboru atrakcij, s katerimi turist pride v stik ob obisku destinacije, in meni, da med njimi obstaja hierarhična razvrstitev. Vse te atrakcije nimajo enakega pomena za posameznega turista, zato jih razvršča v tri kategorije: primarno, sekundarno in terciarno jedro. Podobno kot Botti idr. (2008) se zaveda individualnega odnosa turista do posamezne atrakcije. Primarno jedro je atribut kraja (lokacija, oseba ali 
kulturni element), ki vpliva na odločitev za obisk. Sekundarno jedro je atribut, znan pred obiskom (najpogosteje predhodna izkušnja ali informacija pred odhodom na potovanje), toda ta ne predstavlja pomembnega razloga za obisk oz. ne vpliva na odločitev. Terciarno jedro pa je atribut, ki ga obiskovalec odkrije na sami destinaciji. Leiper torej meni, da je atrakcija empirično razmerje med tremi zgoraj omenjenimi elementi. Zaznamovalec pri tem je predmet, ki da informacijo o znamenitosti, znamenitost sama pa po njegovem ne privlači, pač pa motivira obiskovalce, da doživijo njegovo jedro. $S$ tem Leiper (1990) zanika magnetizem atrakcij in prepričanje, da atrakcije privlačijo obiskovalce, kot je menil Gunn (1997). Avtor meni, da so obiskovalci potisnjeni $\mathrm{k}$ atrakciji (»push «-faktor) na podlagi svoje lastne motivacije, saj verjamejo, da bodo izpolnili svoje potrebe.

Nadalje Leiper zaznamovalce razvršča v tri kategorije glede na način, kako (oz. kje) ti posredujejo informacijo o atrakciji. Tako imenuje zaznamovalce pred odhodom na destinacijo ali obiskom atrakcije (ang. generating markers), zaznamovalce na poti (ang. transit markers) in zaznamovalce, ki informirajo obiskovalca na mestu samem (destinaciji, atrakciji) (ang. contiguous markers). Slednji se nahajajo v jedru sistema atrakcije in se nanašajo nanjo.

Funkcije vseh treh kategorij zaznamovalcev so mnogotere. V osnovi dajejo informacijo o atrakciji, toda poleg tega sprožajo motivacijo za obisk. Tudi ko smo v $\gg$ fazi mirovanja «, torej ko ne nameravamo nikamor potovati, obiskovati atrakcije in podobno, lahko pridemo $\mathrm{v}$ stik $\mathrm{z}$ informacijo o atrakciji, ki deluje na našo motivacijo. Vidimo npr.podobo sanjske vasice na jugu Italije, kjer nas pritegne vzdušje, da bi se lahko popolnoma potopili vanj, vzdušje miru, tradicije, preprostega in umirjenega življenja. Pri tem lahko začutimo melodičnost jezika, čeprav ga ne razumemo, kulturo, vrednote in navade, kar nam lahko predstavlja varno pribežališče $\mathrm{v}$ nasprotju z našim vsakdanom. Stran od vsakdanje rutine podoba sanjske vasice deluje kot nežen zdravilni obliž za razdraženo dušo. V podobi vasice vidimo odrešitev, varno zavetje, prostor, kjer lahko zadihamo s polnimi pljuči, se vrnemo h koreninam vrednot življenja in bistvu. Od trenutka, ko smo prišli v stik s to informacijo (s tem zaznamovalcem), začnemo razmišljati o obisku, načrtujemo čas in sredstva za realizacijo, raziskujemo vse $\mathrm{v}$ povezavi s tem. Torej je ta informacija delovala na našo motivacijo, sprožila proces priprave in načrtovanja obiska ali potovanja ravno tja.

Zaznamovalci v množici podobnih atrakcij in turističnih ponudb prav tako pomagajo pri odločitvah. Večja kot je ponudba podobnih atrakcij, večja je lahko zmeda posameznika in posledično neodločnost. To v povezavi z neizkušenostjo in/ali nezanesljivimi informacijami še bolj pog- 
lablja našo neodločenost, odlašanje in negotovost. Informacija v kakršnikoli obliki, ki prinaša zaupanje, varnost, zanesljivost in odgovarja na naša vprašanja, je tista, ki nas »pelje « $\mathrm{k}$ dejanjem. To je informacija, ki potrjuje naše pričakovanje $\mathrm{v}$ zvezi $\mathrm{z}$ atrakcijo, ki je skladna $\mathrm{z}$ našimi potrebami in zahtevami, ter če ni predhodne lastne izkušnje s točno to atrakcijo, pridejo $\mathrm{v}$ poštev druge podobne lastne izkušnje $\mathrm{z}$ drugimi podobnimi atrakcijami. V kolikor tudi tega ni, se opiramo na tuje izkušnje in priporočila (TripAdvisor, blogi, forumi ...). Pričakovati je, da več kot imamo potovalnih izkušenj, lažje je priti do odločitve in potovanja. Neodločnost lahko pomeni pomanjkanje informacij, neodločni pa smo lahko tudi, če imamo izjemno visoka pričakovanja in visoko stopnjo nezaupanja. Vse to lahko upočasnjuje odločitev. Vloga zaznamovalca je torej tudi ta potreben potisk v smeri odločitve.

Zaznamovalci pa tudi prispevajo $k$ načrtovanju poti, saj je njihova vloga postreči z vsemi potrebnimi informacijami, ki nas bodo peljale do cilja. Kaj vse potrebujemo za prihod na cilj, kakšna je pot, kaj potrebujemo na tej poti, kakšne so varnostne razmere, razmere na cesti, mejnih prehodih, kakšne so vstopne zahteve (vizumi, potni listi, zavarovanja)? Ali je potrebno cepljenje ali druge oblike zdravstvene priprave za obisk atrakcije? Kaj poleg obiska primarne atrakcije še lahko tam počnemo, kaj lahko vidimo in doživimo na sami poti? Sodobni turistični potrošnik ima na voljo omejen čas in znotraj tega razpolaga $\mathrm{z}$ določenimi sredstvi, ki jih je pripravljen porabiti za točno to doživetje, potovanje, atrakcijo. Za svoj denar si želi bogate, polne in celovite turistične izkušnje. Zanima ga, kako si lahko organizira čas na poti do cilja in na samem cilju. Zaznamovalci ali informacije, ki služijo za načrtovanje poti, so dragocen in zanesljiv spremljevalec na poti proti cilju, prispevajo pa tudi k celoviti potovalni izkušnji. To so informacije, ki zapolnjujejo prostor na poti do cilja in je njihova učinkovitost zelo pomembna, saj na poti do cilja v tistemu, ki potuje, deluje proces pričakovanj. Na poti smo zato tudi velikokrat negotovi, dvomljivi in nestrpni, ker ne vemo, ali smo se pravilno odločili. Pogosto potrebujemo dodatne informacije in pomembno je, da so nam te na voljo. Imamo občutek, da smo se izgubili ali zgrešili pot in to seveda terja iskanje, poizvedovanje, orientacijo v prostoru, prilagajanje, čakanje, velikokrat tudi izgubo časa in denarja. Zaradi vsega tega je na poti človek zelo ranljiv, saj je pot do cilja neznana (če gre za prvi obisk) in poleg tega prihaja iz vsakdanjega okolja, kjer je obremenjen s stresom, z delom, vsakdanjo rutino in obveznostmi. Zanj proces sproščanja in popuščanja napetosti še ni dosežen, ker ni prispel do cilja. On sicer potuje k znanemu cilju (informacije o njem že ima, podobo v svojih očeh si je oblikoval z informacijami 
pred samim odhodom), toda informacije na sami poti do cilja so tiste, ki mu vlivajo pogum, da nadaljuje do cilja, da je na pravi poti in ko bo tam, se bo lahko končno prepustil sproščanju in užitku. Informacije na poti $\mathrm{k}$ cilju, torej v tranzitni ali prehodni coni, so za celovito turistično izkušnjo zelo pomembne, saj popotnika varujejo pred neznanim, podpirajo njegovo raziskovanje in prihod do cilja, vlivajo pogum, da je na pravi poti in bo do realizacije svojega motiva prispel varno. Ni odveč poudariti pomena zanesljivosti teh informacij, njihovo pogostost, kakovost in vsebino, saj je na poti turist najbolj »nezaščiten «, ker ni ne doma (v varnem okolju, ki ga pozna) ne na cilju svojega potovanja kamor je bil namenjen in ga pozna na podlagi doslej zbranih informacij in podobe, ki si jo je ustvaril. Je nekako na prepihu med dvema varnima območjema, ki jima nekako zaupa in se jima lahko preda z gotovostjo. V trenutku, ko pa turist doseže svoj cilj (destinacijo ali atrakcijo), je občutek, ki ga ima, kot občutek ob rešitvi uganke, kot sprostitev po naporni poti, ko spusti kovčke na tla varnega, znanega ali predvidenega območja, prostora, kjer je za vse poskrbljeno, kjer ga dočakajo nasmejan in prijazen obraz, pozdrav in iskrena dobrodošlica. Že v naslednjem trenutku je tako revitaliziran, spočit in pripravljen na raziskovanje in odkrivanje - novo turistično izkušnjo.

Zaznamovalci imajo tudi pomembno vlogo na samem kraju (destinaciji ali atrakciji), in sicer prispevajo $k$ izbiri aktivnosti $\mathrm{v}$ povezavi $\mathrm{z}$ atrakcijo. Torej, če je primarna atrakcija znameniti Louvre v Parizu, je vse skoncentrirano okrog njega. Vse svoje aktivnosti in bivanje načrtujemo okrog te primarne atrakcije. Zanima nas, kaj vse ponujajo v bližini, kje so dobre restavracije, bistroji, hotelska soba ali stanovanje, ki ga bomo vzeli v najem, kaj lahko počnemo v prostem času, kam lahko gremo na sprehod, kje so vstopna in izstopna mesta $\mathrm{v}$ javnem prevozu. Zanima nas lahko, če je v bližini gledališče, kamor se lahko odpravimo na priljubljeno ali novo predstavo, zanima nas, kakšna je soseska, $\mathrm{v}$ kateri bomo začasno (turistično) bivali, saj želimo zjutraj na tek ob Seni, nato pa po sveže pecivo ali slaščice, da se posladkamo ob jutranji kavi.

Zaznamovalci pa imajo prav tako pomembno vlogo, ker pomagajo pri identifikaciji cilja (jedra) z množico simbolov in znakov, ki nas peljejo $\mathrm{k}$ jedru, oznanjajo njegovo bližino ali prisotnost v prostoru. Ob njih se počutimo varne, vedno znova nas prepričajo, da je bila naša izbira pravilna, da smo se dobro odločili. Vsaka dodatna informacija ki potrjuje in pomaga pri identifikaciji jedra, je dodaten znak, dodaten impulz za našo domišljijo, pričakovanje in podobo, ki si jo o atrakciji (ali destinaciji) gradimo. Ni odveč pripomniti, kako zelo sta pomembna vsa skrb in znanje o blagovnih znamkah, promociji, marketingu in dizajnu podobe atrakci- 
je. Poleg vse strokovnosti in znanja so potrebne tudi pristnost, vztrajnost in doslednost, saj so to značilnosti kvalitete in vrednosti, ki turistom veliko pomenijo.

Zaznamovalci tudi omogočajo oblikovanje podobe atrakcije (pred obiskom). Neverjetno je, kako vse te informacije ustvarjajo pomembne drobce $\mathrm{v}$ mozaiku podobe atrakcije (ali destinacije) in nenazadnje celovite turistične izkušnje $\mathrm{z}$ atrakcijo. Kot bi vsaka od njih pripomogla, da podobo atrakcije uzremo celostno in večdimenzionalno, z vsemi čutili. Na tak način ji bolj zaupamo, smo pomirjeni, saj nam informacije ponujajo možnost graditve celovitega doživetja. $Z$ zaupanja vrednimi informacijami o atrakciji potrdimo pravilnost »svoje « oblikovane podobe in jo gledamo $\mathrm{z}$ občudovanjem, preseneča nas lahko samo $\mathrm{v}$ pozitivnem smislu, ker je tisto, kar o njej še nismo odkrili, zanimivost in dražljaj, ki bo krepil naš interes in željo, da jo ponovno obiščemo. Kadar samo govorimo o tej izkušnji atrakcije, ki nas je navdušila, so v nas prebujeni občutki sreče in zadovoljstva, ki v našem telesu in možganih izzovejo zelo podobna stanja kot takrat, ko smo tam dejansko bili. Zato je naše posredovanje informacij drugim osebam ali širjenje dobrega glasu o atrakciji pozitivno tudi za nas, ker podoživljamo lepe občutke in se obujajo občutki zadovoljstva, ki smo jih čutili takrat, ko smo bili dejansko tam tudi sami.

Zaznamovalci imajo tako pomembno vlogo, saj omogočajo nabiranje novih in ohranjanje preteklih podob o atrakciji. Vedno znova se polni »baza podatkov《 naših informacij o atrakciji, ali skozi lastno izkušnjo in doživeto atrakcijo iz prve roke ali/in z dodatnimi novimi informacijami o njej. Ne smemo pozabiti, da je tudi atrakcija v nenehni dinamiki in nikoli ni ista, saj se spreminjajo okoliščine, ljudje, ki jo upravljajo, okolje, v katerem se nahaja. Nenazadnje se spreminjamo tudi sami in naše doživljanje atrakcije. Ne vidimo več enako, ne zanimajo nas enake zadeve, ne navdušujemo se nad enakimi detajli, kuristi smo naveličani in izkušenejši, naš prag zahtevnosti se vseskozi spreminja. Zanima nas, kaj se dogaja na mestu, kjer se nahaj atrakcija, tudi, ko nas ni tam, zanima nas, kako se zanjo skrbi, kako se razvija, kakšne novosti ponuja. Ne smemo pozabiti, koliko čustev smo nabrali z izkušnjo(-ami) o atrakciji in kako se je slednja lahko vtisnila globoko v naše življenje, saj se nam je morda prav tam zgodilo nekaj zelo pomembnega (srečali smo življenjskega partnerja, shodil ali spregovoril je naš otrok, prišli smo do prelomne odločitve v življenju ali podobno). Atrakcija ali njeno jedro ima lahko za nas izjemen čustveni naboj ravno zaradi posebnih dogodkov, ki so nas tam ali ob njej zaznamovali in ki se jih bomo še dolgo spominjali. To so vrednote, ki smo jih sposobni dolgo negovati, se k njim vračati in jih častiti. 
Nenazadnje zaznamovalci kot informacije o atrakciji dajo smisel potovanju, ga naredijo pomembnega, ga opredeljujejo, označujejo v primerjavi z drugimi. V različnih življenjskih obdobjih ali situacijah lahko obisku neke atrakcije pripišemo ključen pomen za našo osebnostno rast, prelomnico v življenju, spoznavanje sebe, skratka samorazvoj. Včasih je ta vez $\mathrm{z}$ atrakcijo tako čustveno intenzivna, da nam lahko njena fotografija ali kakšen drug predmet, povezan z njo, predstavlja nekakšen »amulet «. $\mathrm{V}$ avtu imamo glasbo, ki nas je spremljala na tem potovanju in ob njenem poslušanju obudimo občutke, misli, razpoloženja in stanje zavesti, ki nam povrnejo energijo, ko se stežka prebijamo skozi vsakdan.

Richards (2002) ugotavlja, da obstaja pomembna povezava med motivacijo, zaznamovalcem in obiskanostjo atrakcij. V svoji študiji namreč preučuje, kako delujejo povezave $\mathrm{v}$ sistemu atrakcij, tako, da preizkuša delovanje Leiperjevega sistema atrakcij v sodobnem postmodernem turističnem povpraševanju. Meni namreč, da je potreben vsaj en zaznamovalec pred obiskom atrakcije ali odhodom na destinacijo, da bi spodbudil obisk primarnega jedra. Turist je tako motiviran za obisk na podlagi informacije, ki jo pridobi pred odhodom, ta informacija pa se ujema $\mathrm{z}$ njegovimi potrebami in zahtevami. $\mathrm{Na}$ poti so zaznamovalci, ki lahko prispevajo $\mathrm{k}$ odločitvi za obisk drugih atrakcij ali pa »označujejo « pot in vzdržujejo motivacijo turista, signalizirajo, da je na pravi poti. $S$ tem pomagajo oblikovati njegova pričakovanja o jedru oz. njegovih lastnostih. Ob njih se turist počuti varno, saj ugotavlja, da je pot do njegovega (izbranega) cilja prava, prav tako pa ga zaznamovalci na poti dodatno informirajo in potešijo njegovo pričakovanje $\mathrm{z}$ novimi ter njemu koristnimi informacija$\mathrm{mi}$. Ves ta čas namreč $\mathrm{v}$ glavi turista poteka proces oblikovanja podobe $\mathrm{o}$ atrakciji ali destinaciji in zaznamovalci na poti ( $v$ tranzitni ali prehodni coni) imajo odločilen vpliv na to podobo kakor tudi na celovito turistično izkušnjo.

Richards (2002) ugotavlja, da je na osnovi Leiperjevega sistema turističnih atrakcij, kjer so turisti potisnjeni proti atrakcijam na podlagi svoje motivacije, pričakovati močno povezavo med motivacijo, obiskano atrakcijo in uporabljenim zaznamovalcem. Uporaba zaznamovalca je po njegovem $\mathrm{v}$ tesni povezavi s potrebami turistov in $\mathrm{z}$ njihovo motivacijo. Večja kot je motivacija za določene vsebine, večja je verjetnost uporabe zaznamovalca pred odhodom. Informacija, ki jo posreduje zaznamovalec, deluje na potrebe turista tako, da oblikuje pozitivno motivacijo za obisk. Ostali dejavniki, kot so razpoložljiva sredstva in čas za obisk ali potovanje, bodo prav tako imeli vpliv na odločitev turista. Predvideva se, da turisti, ki potujejo v bolj oddaljen kraj ali obiskujejo bolj oddaljeno turistič- 
no atrakcijo, o njej potrebujejo več informacij, saj za tako daljše potovanje porabijo več časa in sredstev. Prav tako tisti, ki v načrtovanje potovanja vložijo veliko časa in denarja, načrtujejo v naprej, se pred odhodom primarno opirajo na zaznamovalce. Čas ima zelo pomembno vlogo pri izbiri zaznamovalca. V kolikor gre za krajši obisk, je pričakovati koncentracijo turista na bolj znane (atrakcije »must see «), saj ima manj časa za raziskovanje destinacije $z$ uporabo zaznamovalcev na destinaciji ali ob atrakciji sami.

Turistični (paketni) aranžmaji so oblike turistične ponudbe, kjer gre pričakovati, da bodo turisti pred odhodom nabrali večino informacij, saj je njihovo potovanje načrtovano v naprej. Zato je uporaba zaznamovalcev pred odhodom pomemben in pretežen vir teh informacij za take vrste potovanja. Obratno pa velja za potovanja, ki so neodvisna, individualna in v domeni posameznika. Ta ima na poti in na mestu samem ponavadi potrebo po informacijah, ki zaokrožujejo njegove potrebe in so v skladu z njegovimi navadami in motivacijo.

Poleg časa in sredstev, namenjenih za potovanje ali obisk atrakcije, imajo veliko vlogo tudi predhodne izkušnje turista, saj tudi te pomembno vplivajo na njegovo odločitev. Poleg tega predhodne izkušnje vplivajo na vrsto izbranega zaznamovalca, saj gre za lastne izkušnje, ki so za turista mnogo bolj zanesljive kot posredne informacije, ne glede na vrsto zaznamovalca. To pomeni, da turisti, ki so že obiskali atrakcijo ali destinacijo, razpolagajo s širšim naborom informacij kot tisti, ki jo obiščejo prvič. Z vidika turistične ponudbe je tudi bistveno lažje prepričati obiskovalca, ki je že imel lastno izkušnjo z obiskom, njegovo zaupanje in odnos (vedenje, odločitev) temeljita na njegovi lastni percepciji, ki ji sam najbolj zaupa. V primeru ponovnega obiska gre z vidika turista za ponovno srečanje $\mathrm{z}$ znanim in varnim okoljem, v katerem (vsaj v osnovi) zanesljivo ve, kaj pričakovati, je pa z vidika turistične ponudbe za takega obiskovalca potrebno vlagati nenehne napore v osvežitev, izboljšavo in nadgradnjo (inovacijo) turistične atrakcije, ki ga bo vedno znova navdušila. Na koncu bo prihajal z namenom, da odkrije, kaj novega mu lahko ponudijo, kako ga še lahko očarajo in prepričajo z vrhunskim tretmajem. Iz tega izhaja, da obiskovalec, ki prvič pride na obisk atrakcije, ravno tako potrebuje veliko ponudbenega angažmaja, toda njegova neizkušenost mu pušča na voljo veliko večje število (če ne množico) primerljivih atrakcij, med katerimi se odloča. Ni dovolj poudariti, kako zelo je pomembno, da njegovo celotno doživetje prvega obiska naredimo kar se da vrhunsko, brezhibno. Dejansko ga je ob tem prvem obisku potrebno pridobiti s t. i. »wow-efektom «, ujeti njegovo pozornost z drugačnostjo, 
izstopiti iz množice in prepričati. Ta aktivnost od turistične ponudbe zahteva veliko več napora kakor ohranjanje pozornosti, negovanje odnosa $\mathrm{z}$ večkratnim obiskovalcem.

Richards (2002) v svoji študiji ugotavlja, da so najpogosteje in v največji meri v uporabi zaznamovalci pred odhodom na potovanje ali obiskom atrakcije. Slaba polovica vprašanih v raziskavi $(\mathrm{N}=6000)$ se opira na informacijo pred potjo, slaba četrtina pretežno na informacije med potjo oz. na poti in nekaj več kot četrtina na informacije na destinaciji oz. ob atrakciji sami. Dnevni obiskovalci po informacijah pred odhodom posegajo pretežno zaradi omejenega časa za obisk, ki jim je na voljo. Tisti na turističnih potovanjih pretežno uporabljajo informacije na poti, bolj kot tisti, stacionirani na eni lokaciji. Daljše bivanje na destinaciji omogoča uporabo informacij na poti in destinaciji sami, ker je na voljo več časa. Prav tako daljše bivanje pomeni iskanje in obiskovanje tudi manj znanih atrakcij. Pomembno sporočilo avtorjeve študije za turistični marketing je bilo sledeče: pozornost (potencialnih) obiskovalcev in turistov je potrebno ujetii pred njihovim odhodom od doma. Prav tako je ugotovil, da uporaba zaznamovalcev zelo variira $\mathrm{v}$ odvisnosti od kulturnega kapitala (pretežno izobrazbe) in potrošniških navad ter spretnosti. Predvsem pa je ugotovil moč predhodne lastne izkušnje kot pomembnega zaznamovalca pred odhodom, ki nastopa v sistemu atrakcij kot neposreden in izjemno zanesljiv vir informacij za turista.

Leiperjev sistem turističnih atrakcij je uporaben za razumevanje načina, kako destinacije privlačijo obiskovalce, vzorcev in lastnosti obiskovanih atrakcij ter njihove vloge kot ključnih elementov destinacij. Prav tako je uporabnost tega modela možna pri raziskovanju učinkovitosti takih sistemov ter analiziranju različnih zaznamovalcev, ki jih turisti koristijo (Richards, 2002). Preverjanje učinkovitosti sistema atrakcije $\mathrm{z}$ uporabo Lepierjeve strukture je potencialno zanimivo in aplikativno orodje tudi v praksi.

\section{Model turistične atrakcije}

Zgoraj smo obravnavali Leiperjev sistem turistične atrakcije, v katerem deluje povezava treh elementov: turista (človeški element), jedra (ključni element) in zaznamovalca (informativni element). Vse te elemente smo predhodno podrobno predstavili s poudarkom na njihovih lastnostih, vlogah v sistemu atrakcij in povezavah med njimi. Predstavili smo človeški element $\mathrm{v}$ sistemu atrakcije, njegov pomen, njegove dinamične in statične lastnosti. Jedro, ki predstavlja ključni element atrakcije, smo razdelili v tri kategorije glede na percepcijo turista, pri čemer pomembno vlogo 
igra čas, ki ga turist posveča jedru atrakcije. Temeljito smo opredelili tudi informativni element sistema atrakcije, njegove vrste in ključno kot tudi njegove posamezne vloge.

Model turistične atrakcije, ki ponazarja delovanje tega sistema, je med prvimi oblikoval sam Leiper (1990), nato pa so še drugi avtorji poskušali oblikovati podobne modele, med slednjimi tudi Kušen (2oro). $\mathrm{V}$ nadaljevanju in $\mathrm{v}$ povezavi s sistemom turistične atrakcije (natančneje z njegovim delovanjem) želimo predstaviti pomen prostorskega in industrijskega elementa, ki prav tako zaznamuje sistem atrakcij.

Omenjeno je bilo, kako zelo pomemben je prostor kot element sistema atrakcije; ta je (podobno kot človeški element) prisoten na strani ponudbe in povpraševanja. Pa vendar, turistični viri izhajajo iz fizičnega in družbenega prostora, torej je geografsko, družbeno in ekonomsko gledano prostor temeljna prvina v sistemu turistične atrakcije. Prostor je prisoten $\mathrm{v}$ domicilni, emitivni regiji, od koder prihaja turist, prostor je pomemben element tudi v ciljni, receptivni regiji (destinacija, atrakcija), kamor je turist namenjen. Prostor med tema dvema poloma pa je t. i. tranzitni ali prehodni prostor, ki prav tako pomembno vpliva na percepcijo turista $\mathrm{v}$ času realnega gibanja (potovanja) in na njegovo celovito turistično izkušnjo z destinacijo oz. atrakcijo. O tem delu prostora z marketinškega vidika in vidika upravljanja turističnih atrakcij vemo najmanj, zato se mu bomo tukaj nekoliko bolj posvetili.

Ves napor turističnega gospodarstva je namreč skoncentriran na ciljni prostor (receptivno regijo), ker se tam nahaja(jo) atrakcija(-e), turistična ponudba, turistična infrastruktura in podobno. $\mathrm{V}$ tem delu prostora turističnega sistema pa je poleg prostora, kjer najdemo turistične vire in atrakcije, prisoten tudi industrijski element, ki pomeni turistično infrastrukturo, ponudbo, podjetja, organizacije, javni transport, nastanitev, gostinstvo in druge storitve.

Lahko bi rekli, da je industrijski element, podobno kot človeški, dinamičen in statičen hkrati. Njegova dinamika se kaže v nenehni spremembi (kvantitativni in kvalitativni) zaradi razvojnih tokov v turizmu, tehnologije in investicij v turistično infrastrukturo, nastanitveni sektor, turističnih in s turizmom povezanih organizacij, podjetjij, transporta, storitev in drugo. Te spremembe se dogajajo pod vplivom turističnega trga, zahtev turistov in turističnih trendov. Statičnost industrijskega elementa pa se kaže v fizični prisotnosti infrastrukture, zgradb, logistike in zaposlenih z vso njihovo ekonomsko in tržno vrednostjo. Kakovost in učinkovitost industrijskega elementa je zelo pomembna, saj so njegove lastnosti v direktni povezavi z jedrom atrakcije, ki je odvisna od motiva za obisk. 
Kot je razvidno iz slike $\mathrm{I}$, lahko o domicilni regiji ali izhodiščnem prostoru razmišljamo kot o naravnem in družbenem prostoru, ki zaznamuje turista, je del njegove kulturne identitete, prostor, ki mu je znan in iz katerega izhaja, torej je domač in s tem tudi del njegove domače kulture, navad, vrednot in vedenjskih vzorcev. To je prostor, $\mathrm{v}$ katerem se turist začne pripravljati na obisk atrakcije ali potovanje in v katerem ima na voljo varno zavetje znanega ter ustaljenega vsakdana, ki ga pozna in mu zaupa. Toda, v tem vsakdanjem okolju, podvržen delu in rutini, se čez čas naveliča, je pod stresom in drugimi pritiski, ki ga potiskajo $\mathrm{v}$ razmislek (idejo, željo, potrebo) po spremembi v obliki turističnega obiska ali potovanja, nato pa tudi v aktivno dejanje potovanja $\mathrm{v}$ realnem prostoru. Misel o obisku atrakcije ali potovanju spodbudi informiranje, raziskovanje in poizvedovanje o predmetu interesa (atrakciji, destinaciji), zato $v$ tej fazi posega po različnih virih, od koder črpa ustrezne informacije. $V$ času, ko to počne, sanjari o spremembi, odhodu iz vsakdanjega okolja, obisku atrakcije, v njem naraščata hrepenenje in radovednost o tem, kaj mu sprememba lahko prinese. Dovolj so že kratek odmik od znanega in nova izkušnja, počitek ali odklop. Na podlagi zbranih informacij začne oblikovati podobo o atrakciji ali destinaciji, realnost te podobe pa je odvisna od predhodne lastne izkušnje, priporočila prijateljev, vse do drugih virov informacij (oglasi, brošure, filmi), na katere se bolj ali manj zanese. Hkrati s podobo in v povezavi z njegovimi notranjimi motivi, vrednotami, navadami in potrebami se začnejo oblikovati pričakovanja glede atrakcije, ki jo želi obiskati. Na podlagi tega procesa v njem $\gg$ zori« pričakovanje in to posledično pripelje do odločitve o nakupu, obisku oz. potovanju. $V$ tem delu so seveda pomembni številni parametri, kot so cena, vrednost, ki jo dobimo za ceno, časovni okvir, logistična vprašanja in podobno, kar bo posameznika definitivno pripeljalo do končne odločitve in nakupa. Ko pride do odločitve, so ga od konkretnega dejanja potovanja ločujejo samo še časovna dinamika, načrt in priprava na realno potovanje v prostoru. Ko do odhoda dejansko pride, govorimo o potovanju (ne glede na razdaljo) in v osnovi je to turistično potovanje, saj se na poti iz domicilne regije posameznik vede kot turist in ima turistične potrebe. Ta fenomen vedenja in značilnih turističnih potreb, povezanih s tem vedenjem, imenujemo turistična kultura, ki je značilna za vse sodobne turiste. Gre za vrsto kulture, ki nastane v gibanju, na turističnem potovanju, in ni del nekega kulturnega ali zgodovinskega okolja $\mathrm{v}$ fizičnem smislu. Turistično kulturo najbolje ponazorimo s podobo turistov na poti do izbrane destinacije, 
ki čakajo na prevoz, raziskujejo destinacijo, »oboroženi«s fotoaparati, ali iščejo izgubljeno prtljago. Zanimivo je, da posameznik, ki se podaja na »pot«, že v trenutku, ko prične s pripravami (npr. pakiranje), prevzema za turiste značilne vedenjske vzorce: na eni strani sproščenost od vsakdanjih obveznosti, pričakovanje drugačnosti in nove izkušnje, na drugi pa določeni varnostni ukrepi (npr. domača lekarna za vsak primer), različni potovalni atributi in pripomočki, ki prispevajo k udobju ali drugače pomagajo na potovanju (dodatne količine vode, hrane, obutev itn.).

$\mathrm{V}$ nadaljevanju se posvečamo tranzitnemu ali prehodnemu prostoru $\mathrm{v}$ sistemu turistične atrakcije, ki je del prostorskega elementa, toda njegova pozicija je vmesna med izhodiščnim in ciljnim prostorom. Na sami poti (odvisno od razdalje) se lahko marsikaj pripeti in previdnost nikoli ni odveč. Dlje ko traja pot, večji je lahko napor ob potovanju (odvisno od prevoznega sredstva, udobja potovanja in podobno), pa tudi pričakovanje srečanja $z$ atrakcijo oz. destinacijo narašča. $V$ predhodnem poglavju smo razložili vse povezano z zaznamovalci v tem segmentu; kako delujejo, zakaj in kako jih uporabljamo in kako zelo so pomembni. $\mathrm{V}$ tej prehodni coni so negotovost, pričakovanje pa tudi nestrpnost turista lahko na višku, zato je tukaj morda najranljivejšu. Potrebuje informacije, ki nedvomno in zagotovo peljejo $\mathrm{k}$ cilju, potrebuje storitve na poti, da bo ta potekala kar se da ugodno in udobno. Marketing v turizmu se v tržnih raziskavah premalo ukvarja s tem delom potovanja, bolj je skoncentriran na sam turistični kraj, atrakcijo ali destinacijo. Tudi izhodiščna ali domicilna regija ni tako poznana ponudnikom v turizmu, saj je koncentracija njihovih aktivnosti in razumevanja vedenja turista bolj vezana na sam cilj, kamor turist prihaja. To seveda pomeni, da turista kot ponudniki turističnih storitev ne poznamo dovolj, saj je nekdo turist na celotni poti in ne šele ob prihodu na cilj. Potrebno je poznati njegovo vedenje, motive, navade, okuse in potrebe, še preden se potovanja ali obiska sploh loti; na to opozarjajo prej navedene raziskave (npr. Richards, 2002), ki nedvomno ugotovavljajo, da večina ljudi informacije o atrakciji nabira še pred dejanskim potovanjem. Prav tako je potrebno vedeti vse o tem, kako poteka potovanje, ali ima turist zadostne in ustrezne informacije o cilju, kako se na poti počuti, kako jo doživlja in kako to vpliva na njegovo celotno izkušnjo $\mathrm{z}$ atrakcijo.

Ob prihodu na cilj se podoba o atrakciji, oblikovana v glavi turista ob njegovi motivaciji in pričakovanjih, sreča z realno podobo atrakcije ali destinacije in to je odločilni trenutek, ki bo poleg celotnega turističnega obiska, bivanja in doživetja v celoti opredelil stopnjo zadovoljstva. 


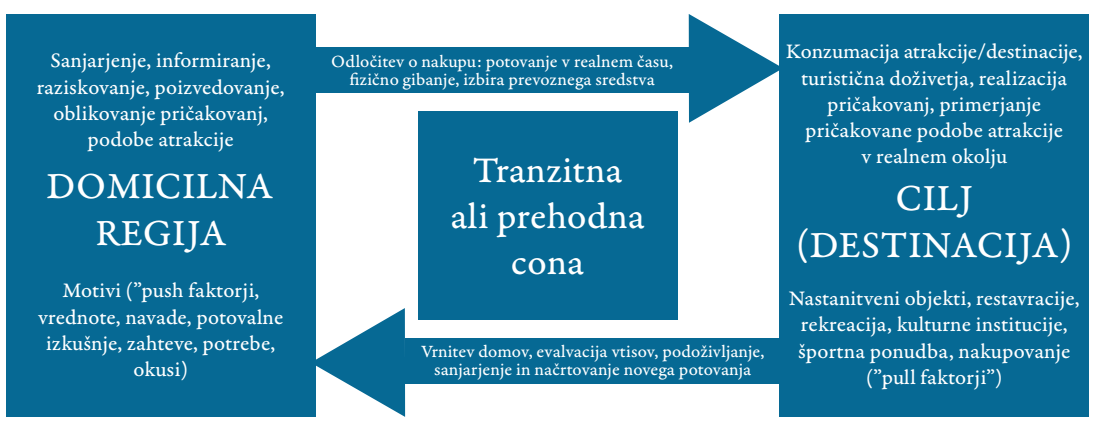

Slika I: Model turistične atrakcije in faze turistične potovalne izkušnje

Vir: Prirejeno po Leiper, 1990.

Na tem mestu turist uporablja turistično infrastrukturo, storitve, kupuje različne proizvode in je $\mathrm{v}$ neposrednem stiku $\mathrm{z}$ jedrom atrakcije. Tukaj je njegova turistična izkušnja morda najintenzivnejša zaradi fizične prisotnosti, konzumacije in preživljanja časa med turističnim obiskom. Ob tej izkušnji se porajajo različni občutki, gradi se njegov odnos in oblikuje ocena doživetega, kar po končanem obisku (pa tudi med njim) primerja s predhodnimi lastnimi podobnimi izkušnjami, pričakovanji in podobo, ki si jo je ustvaril pred obiskom (tukaj se srečata njena ustreznost in dejanska potovalna izkušnja, ob kateri neposredno spozna, kaj si v prihodnje želi, česa pa ne). Misel na to, da bo spet prišel čas za obisk atrakcije ali potovanje, ga navdaja $\mathrm{z}$ novim pričakovanjem, hrepenenjem in potrebo po spremembi. To bo lahko realiziral, ko za to pride pravi čas, do takrat pa sanjari, načrtuje, se informira, poizveduje in $s$ tem je krog potovanja sklenjen.

Če povzamemo, je v prvem delu modela sistema atrakcije turist potoval $\mathrm{v}$ mislih, torej je to svojevrstno duhovno potovanje, kot ga imenuje tudi Urry (2005), ko pravi, da se potovanje začne, še preden se nanj dejansko odpravimo. Nato sledi dejansko potovanje v prostoru, skupaj s turističnim obiskom ali bivanjem, in se zaključuje spet $\mathrm{z}$ duhovnim potovanjem ob povratku v izhodiščno (domicilno) regijo. O turistični izkušnji v povezavi s turistični proizvodom bomo spet pisali v predzadnjem poglavju te knjige, kjer bomo opozorili tudi na druge vidike obravnave te problematike, predvsem marketinškega. 



\section{Evolucija turistične atrakcije ali MacCannellov proces sakralizacije}

V svojem znamenitem delu The tourist: A new theory of leisure class (1976), Dean MacCannell primerja turista s sodobnim romarjem, turistične atrakcije pa s sodobnimi svetišči. Turistično potovanje avtor vidi kot modernistično manifestacijo sodobnega turista, podobno svojevrstnemu ritualu, ki ima za cilj samoaktualizacijo skozi avtentično ali manj avtentično turistično izkušnjo. MacCannell namreč fenomen turizma razlaga na podlagi njegovega naraščajočega pomena v moderni družbi, ki je menda odraz sodobne odtujene družbe in človeka. Vezano na to, kot tudi izhajajoč iz teorije potrošništva, kjer je turistična izkušnja vezana na svojo ekonomsko funkcijo skozi dejanje turistične potrošnje, je tudi ogledovanje turističnih atrakcij za avtorja svojevrsten ritual. Pogoj je le, da ima atrakcija neko prepoznavno družbeno vrednost - ta je namreč družbeni fenomen in jo pridobi s časom in skupaj z ekonomsko vrednostjo, ki pa je pogoj, da atrakcija postane del ponudbe turističnega trga. Da bi to postala, gre vsaka atrakcija skozi proces sakralizacije (ang. sight sacralization), ki ga MacCannell opiše skozi pet faz.

Imenovanje (ang. naming) je prva faza $\mathrm{v}$ procesu sakralizacije, kjer prihaja do označevanja ali imenovanja kraja, objekta, osebe, predmeta ali zgodbe, ki predstavlja zasnovo za atrakcijo. $S$ tem se neko pojavnost označi in imenuje. Latinski pregovor $\gg$ Nomen est omen «, ki ga pri nas prevajamo kot $\gg$ Ime ima pomen « ali »Ime je znamenje«, nas opomni, da je ime pomembno, saj zaznamuje, predstavlja pomen imenovanega, priča o njegovih lastnostih in vrednosti,ga nek način opisuje, predstavlja, kar je pomembno, saj si na podlagi imena lahko ustvarimo sliko imenovanega, se lažje znajdemo pri njegovi obravnavi v primerjavi z drugimi. Ime torej 
atrakciji določa pomen in vrednost, a to je le začetek. Če se na kratko navežemo na definicije turističnih atrakcij v drugem poglavju, je evidentno to, da se velika večina začne $s \gg$ Turistična atrakcija je imenovan stalni vir«, kar pomeni, da je ime atrakcije ključno za njeno prepoznavnost, ločevanje od drugih ter nenazadnje marketing in pozicioniranje na turističnem trgu.

Naslednja faza MacCannellovega procesa sakralizacije je uokvirjanje (ang. framing) in povišsevanje (ang. elevating). Okvir okrog objekta, ki je zasnova za atrakcijo, na nek način povzdigne njegovo vrednost, saj objekt zaščiti in poudari na način, da usmerja pozornost na tisto, kar je v okvirju. Ponavadi se za ta namen uporabi steklena vitrina, reflektor, posebna osvetlitev ali ograja, ki usmeri pogled na »bistvo « tistega, kar je v okvirju. Vse, kar je pomembno in želimo pokazati, na nek način uokvirjamo: slike, diplome, certifikate. $S$ tem poudarimo pomen uokvirjenega, to predstavimo na vidnem mestu, z vso njegovo impozantnostjo in pomenom, ki se mu pripisuje. Okvir naredi sliko. Če imamo pravi okvir, pride tudi slika v njem bolj do izraza, je opaznejša, izrazitejša, kliče po pogledu. Okvir torej povzdigne pomen vsebine v njem.

Tretja faza v procesu sakralizacije je Zapiranje v svetišče (ang. enshrinement). $\mathrm{V}$ tej fazi število obiskovalcev atrakcije narašča, ta pridobiva reputacijo in prepoznavnost, njen pomen $\mathrm{v}$ družbi se krepi, toda skrivnostnost v zvezi z njo (in njeno »svetostjo «) povečuje omejevanje njene izpostavljenosti, $s$ tem pa se krepi zanimanje še večjega števila obiskovalcev. V kontekst te faze sodijo omejitve, povezane z obiskom atrakcije, v obliki vstopnine, uradnih ur obiska, omejitev pri snemanju ali slikanju, posebnih razmer $\mathrm{v}$ prostoru, kjer se atrakcija nahaja (npr. svetloba, zvok, vlaga in temperatura zraka), z namenom ohranjanja prvobitnosti, avtentičnosti ali njene osnovne kakovosti. Ob tem se v bližini atrakcije pojavljajo tudi razna opozorila in prepovedi, ki obiskovalca opominjajo na nje-

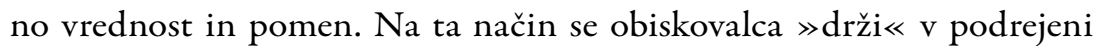
vlogi občudovalca, poveličevalca, oboževalca. Družbena vrednost atrakcije $\mathrm{v}$ tej fazi je zagotovljena in evidentna.

Mehanska reprodukcija je četrta faza v procesu sakralizacije, ko se v neposredni bližini originala (npr.v muzeju, turističnih pisarnah, kioskih za nakup vstopnic ipd.) obiskovalcem omogoča nakup spominkov, kopij, vzorcev atrakcije ali fotografij, posterjev, plakatov in knjig o atrakciji. Funkcija teh predemtov je, da obiskovalca $\gg$ peljejo $\ll$ k originalu, ga opominjajo nanj, pomagajo obujati spomine. $S$ tem vzpodbudijo željo in potrebo, da se atrakcijo obišče in doživi. Pri tem je treba poudariti, kako zelo je pomembno za ponudnike turističnih atrakcij paziti na kakovost 
teh izdelkov, smiselnost in avtentičnost. V preteklosti, zlasti v obdobju množičnega turizma, je bilo veliko kritičnih razprav o takih predmetih kot »trofejah «s potovanj, s katerimi so se lastniki postavljali pred prijatelji, razkazovali svojo moč ali prestiž (npr. slonji okli ali korale iz tropskih morij); tako početje je po mnenju kritikov več govorilo o vrednotah in kulturi takega posameznika kot o njegovem turističnem doživetju ali predmetu samem.

Socialna reprodukcija je po MacCannellu zadnja faza v procesu sakralizacije, ki pa zajame širše družbeno okolje na način, da se to poistoveti z atrakcijo, jo vzame za svojo. Ljudje, mesta in regije lahko identiteto atrakcije prevzamejo za svojo in jo ponotranjijo. Na tak način odražajo njene lastnosti, so del nje, čutijo povezanost $\mathrm{z}$ njo, kar turist dojema kot avtentično izkušnjo. Na tak način je atrakcija »živa « in je del celotnega naravnega in družbenega okolja. Odveč je omenjati ponos in pripadnost, ki ga lahko domačini čutijo $v$ tem primeru, toda prav tako je treba opozoriti tudi na pasti komodifikacije, komercializacije, zaigranosti in nepristnosti, kar pa je škodljivo za domačo družbeno skupnost kot tudi za turiste in turizem, vsaj na dolgi rok. 



\section{Zgodovinski razvoj turističnih atrakcij}

Preden začnemo z obravnavo o zgodovinskem razvoju turističnih atrakcij, je treba stopiti še korak ali dva nazaj in osvetliti nekatera izhodišča za razumevanje razvoja turističnih atrakcij skozi čas. Pojav turizma nedvomno povezujemo s spremembami družbenih procesov, spremembami na relaciji med delom in prostim časom, spremembami družinske strukture, spremembami v dimenziji in razumevanju časa itn. Znotraj tega se pojavlja fenomen prostega časa kot prepoznana dimenzija v življenju ljudi in kot značilno družbeno vedenje. Prosti čas se torej pojavi kot neposreden rezultat tehnološkega razvoja, ta pa je pogoj za turistično aktivnost.

\section{Izhodišča obravnave turističnih atrakcij skozi čas}

Prosti čas kot koncept razumemo kot čas, v katerem posameznik svobodno in samostojno odloča o tem. kaj bo počel. in pri tem izbira na podlagi svoje notranje motivacije, kar sproža njegovo zadovoljstvo. Torej je prosti čas koncept, ki ga razumemo v nasprotju do dela in obveznosti ali nuje.

Zanimanje znanstvenikov za ta fenomen se je začelo $z$ družbenimi spremembami, zlasti spremembami $v$ tehnologiji in načinu proizvodnje, ki so v družbi sprožile val sprememb. Mislimo na čas začetka industrijske revolucije, ko je manufakturo kot koncept proizvodnje zamenjala mehanizirana proizvodnja. Ta je omogočila krajši čas proizvodnje večjega števila proizvodov, kar pomeni nižje stroške in večjo dostopnost teh proizvodov v družbi. $Z$ načinom proizvodnje oz. dela se je spremenil tudi način življenja. $S$ temi spremembami prihaja do ločevanja kraja dela od kraja bivanja, kar je temeljni sprožilec koncepta prostega časa. Z nadalj- 
njim industrijskim razvojem je prišlo do organiziranega pojavljanja javnih institucij, kot so parki, otroška igrišča, centri različnih aktivnosti, kulturni centri, lokalna združenja ipd. (Pronovost, 2000, str. 358). Tak koncept institucionalizacije prostega časa je znan kot rekreacija, to je aktivnost, ki v osnovi temelji na igri. Sprva so prosti čas kot eno od kategorij družbene kulture obravnavali antropologi (Pronovost, 2000), nato pa so koncept v obravnavo vzeli tudi sociologi in nastajati je začela veja sociologije, ki je obravnavala prosti čas. Znotraj tega so obravnavali različna znanstvena področja, med drugim tudi turizem, saj je prosti čas pogoj za nastanek turistične aktivnosti. Znanstveno preučevanje in pomen prostega časa je ključno za razvoj turizma, saj osvetljuje vzgibe za turistično aktivnost in vedenje.

Da bi razumeli turistično aktivnost, moramo razumeti turizem. Toda ta je v teoriji bolj osredinjen na vprašanji »kaj《 in »kako《kot na vprašanje »zakaj«, kar ne prispeva k postavljanju temeljev za njegovo suvereno znanstveno preučevanje (Dann, 2000, str. 369 ), temveč ga postavlja ob bok industriji (zato turistična industrija), saj se opiramo pretežno zgolj na njegove (poslovne) učinke. Turizem tako ostaja v domeni stroke in ne znanosti.

Turizem kot družbeni fenomen je novejšega datuma v primerjavi z drugimi družbenimi fenomeni, kot sta npr. status ali vera. Teorija turizma je zaenkrat skromna, za vsako teorijo pa velja, da ima tri osnovne funkcije. Prvič, če razumemo, zakaj se nekaj dogaja, potem lahko napovemo, kdaj in ob kakšnih okoliščinah se bo zgodilo v prihodnje, drugič, z razumevanjem teh dogodkov lahko nadzorujemo in vplivamo na prihodnje dogodke, in tretjič, vse teorije lahko usmerijo raziskovalne napore oz. opredelijo smer empiričnih odkritij (Babbie, 1995, v Holden, 2004, str. 5). Tako je po mnenju mnogih avtorjev (Holden, 2004), turizem bolj področje preučevanja kot disciplina za sebe, saj nima svojih lastnih teorij, kot so motivacijska, teorija ekonomskega multiplikatorja, razvojna teorija ipd.

Preučevanje turizma je v zadnjih petih desetletjih pridobilo na znanstveni reputaciji s povezovanjem $z$ različnimi disciplinami, zato multidisciplinarno preučevanje vse bolj nadomešča interdisciplinarno preučevanje turizma. Interdisciplinarnost je vključujoča, išče povezave in napredek $v$ znanju in razumevanju, medtem pa multidisciplinarno preučevanje znanstvenikom omogoča le parcialno ali enoplastno videnje in razumevanje nekega pojava, kajti vsaka znanstvena disciplina (npr. sociologija, antropologija, geografija, ekonomija, politologija, zgodovina) ima svojo značilno metodologijo, pristope in instrumente. Evidentne spre- 
membe v družbi na podlagi vseprisotnega turizma v svetu segajo dlje od njegovih ekonomskih, kulturnih, okoljskih in političnih učinkov. Turistična aktivnost in vedenje ne zadevata samo turistov in domačinov, pač pa tudi vse $\mathrm{v}$ kolesju turističnega in s turizmom povezanega fenomena. Zaradi vsega tega je slednjemu vredno posvetiti ustrezno pozornost, ga dojeti in prepoznati kot pomembnega soustvarjalca sodobne družbe.

Torej, če gre za družbeni fenomen in spremembe, ki jih ta sproža, je smiselno opazovanje teh sprememb in dogodkov skozi čas. Toda, kje je začetek tega časa? Za turizem smo rekli, da je novejšega datuma, a vendarle so predhodna dejanja in vedenje posameznika v družbi vplivala na potrebe in vzorce vedenja, značilne za (sodobni) turizem. Na podlagi zgodovinskih dognanj bi lahko rekli, da je človek že v prazgodovini imel nekaj, kar je najpodobnejše tistemu, kar danes razumemo kot prosti čas na individualni ravni. Ko je nehal loviti, ko je bil na varnem, torej ko so bile zadovoljene njegove primarne potrebe, je $\mathrm{v}$ sproščujočem vzdušju počel marsikaj drugega. Morda zadostuje, če omenimo samo prve jamske ali stenske poslikave, kot obliko najzgodnejše umetnosti v Evropi, ali pa prvo piščal na svetu, ki je najdena na naših tleh (Divje babe), kot najstarejše najdeno namensko glasbilo na svetu. Izhodišče za turizem smo našli v prostem času, ker je ta podlaga za turistično aktivnost, ta pa ni nujno vezana na potovanje, lahko je tudi del lokalnega, domačega prostora.

Večina avtorjev (Swarbrooke, 20I2; Holden, 2004) zgodovinski pregled razvoja turizma in turističnih atrakcij povezuje s prvimi civilizacijami in odkriva značilne vzorce ter navade $\mathrm{v}$ vedenju oz. načinih preživljanja prostega časa. Te značilnosti so povezane tudi s filozofijo življenja in $\mathrm{z}$ verovanji, $\mathrm{s}$ kulturo in tehnološkim ter političnim razvojem neke civilizacije. Tako se v odkrivanju značilnosti vedenja, ki ga danes prepoznamo za turističnega, sprašujemo o temeljnih vprašanjih, vezanih na turizem: zakaj človek potuje, kam potuje, zakaj potuje in kako potuje? Ali če zastavimo širše, kar je nujno za področje turističnih atrakcij, kjer je v centru dogajanja obiskovalec ( $\mathrm{tj}$. širše zastavljena publika od samo turistične): zakaj človek obiskuje določene atrakcije, kaj obiskuje, zakaj jih obiskuje in kako to počne? Navkljub takim temeljnim vprašanjem, se velika večina turistične literature začenja z izdatnimi statističnimi podatki o skokovitem naraščanju števila obiskovalcev in turistov, o njihovih prenočitvah in potrošnji. Zato smo še zmeraj na začetku skromne turistične teorije, saj je za njeno znanstveno uveljavljenost najprej potrebno podrobno odgovoriti na temeljna vprašanja, šele nato pa se ukvarjati z vidnimi, aktualnimi dogodki, ki jih lahko statistično spremljamo in napovedujemo. 


\section{Zgodovinske prelomnice $\mathrm{v}$ razvoju turističnih atrakcij}

Ko govorimo o zgodovini turističnih atrakcij, dejansko govorimo o družbenih spremembah, ki so privedle do aktualnosti in pomena turističnih atrakcij, kot jih poznamo danes. V najširšem okvirju zgodovine je človek od zmeraj imel potrebe početi »nenujne « zadeve v svojem življenju. Tukaj »nenujnost « povezujemo $\mathrm{z}$ vsemi aktivnostmi, ki niso vezane na preživetje in primarne potrebe, je pa družbena sprememba edina konstanta. Znotraj nje lahko najdemo značilne dogodke, ki so na določen način vplivali na vedenje ljudi in njihovo početje. $V$ tej obravnavi pa ne gre mimo dejstva, da sta za turizem ključnega pomena domeni časa in prostora, torej bi lahko sklepali, da korenine preučevanja turizma izvirajo iz geografije in zgodovine. Nadalje je treba poudariti le še pomen konteksta. Turizma ne moremo razumeti izven družbenega in ekonomskega konteksta, zato vse dogodke in prelomnice razumemo izključno s postavitvijo v ustrezen kontekst.

Starogrški zgodovinar Herodot (484 p. n. š. -425 p. n. š.) je znan kot začetnik evropskega zgodovinopisja, saj je skladno s prvimi dostopnimi oz. ohranjenimi zapisi prvi obravnaval zgodovino kot raziskovalni primer, znan pa je tudi kot prvi potopisec. V svojem času naj bi potoval po Egiptu, Siriji, Mali Aziji, Perziji, Siciliji in Babilonu ter zapisoval svoje vtise o teh potovanjih (Sharpley, 1999, v Holden, 2004).

Prvi dokazi o turizmu segajo v antično Grčijo, kjer so zabeležena potovanja z namenom obiskovanja preroških mest, festivalov ali športnih tekmovanj. Prve olimpijske igre (776 p. n. š.) štejemo za enega izmed prvih takih dogodkov oz. potovanj ljudi z namenom udeležbe na športnih igrah. Toda grška filozofija prostega časa je izjemno pomembna v teoriji prostega časa in turizma, kot ga poznamo danes. Grški filozofi namreč prvi postavijo jasno ločnico med delom in prostim časom. Za Grke je prosti čas dimenzija življenja, ki plemeniti posameznika in družbo. Prosti čas namreč tesno povezujejo $s$ kakovostjo življenja ter z zdravjem posameznika in družbe kot celote. $\mathrm{V}$ prostem času naj bi imel posameznik možnost za duhovno rast zlasti skozi šport, kot zaželeno fizično aktivnost, toda tudi skozi umetnost; zlasti glasbena in dramska naj bi prispevali $\mathrm{k}$ razvoju. Grki imajo prosti čas za povezavo z bogovi in razvojem osebnosti. Skozi sanjarjenje in podobno mentalno aktivnost naj bi se krepila modrost, to pa je bilo možno le v prostem času. Ker je prosti čas pripadal samo svobodnim ljudem, je bil razumljen kot privilegij, zlasti zato, ker so menili, da sta za prosti čas potrebna izobrazba in intelekt. Za Grke je bil prosti čas iskanje resnice, osvobojen materialnih obveznosti, šlo je za proces ugotavljanja zakonitosti narave in sveta skozi samoizražanje. Pros- 
ti čas za Grke pooseblja vso radost in užitek do življenja, lahko bi rekli, da časti življenje v vsej njegovi veličastnosti, zato prosti čas zanje ni samo osebno zadovoljstvo, pač pa tudi javno dobro (Holden, 2004). Problem pa je v tem, da je javno dobro dostopno zgolj svobodnim moškim in je s širše perspektive, torej glede na to, da gre za sužnjelastniško družbo, njegov pomen absurden.

Rimljani so prosti čas poznali z namenom, saj je njihova filozofija prostega časa temeljila pretežno na čutnem in estetskem zadovoljstvu. $\mathrm{Na}$ osebni ravni namreč veljajo za uživače pri hrani, zabavi in v življenju nasploh. Gradili so javno opremo za številno urbano populacijo in njeno fizično rekreacijo (npr. priprave legionarjev za vojne pohode). Značilnosti zapuščine Rimljanov se kažejo predvsem v gradnji sofisticiranega cestnega sistema, ki je z vidika potovanja in dopustovanja pomembna iz logističnega in varnostnega pomena. Gradnja cest omogoča hitrejšo dostopnost in potovanja zaradi druženja ter obiskovanja družine in prijateljev. Meščani so radi »pobegnili« iz pregretega poletnega Rima na zahodno obalo v Neapeljski zaliv, ki je imel takrat renome mondenega turističnega središča, saj so tam gradili poletne domove (rimske vile) (Holden, 2004). Poleg cest sta značilno vlogo igrala skupni jezik (latinščina) in valuta, ki sta veljala v celotnem cesarstvu, to pa je v najboljših časih segalo od Anglije na zahodu do Sirije in Armenije na vzhodu (Holden, 2004). Poleg tega so Rimljani prvi prepoznali zdravilne lastnosti termalnih virov (spa) in gradili terme, te pa $\mathrm{v}$ turistični ponudbi poznamo še danes. Po drugi strani pa vpeljejo značilno obliko organiziranega prostega časa, to so gladiatorske igre. V letoviščih na neapeljski obali in tudi na gladiatorskih igrah je veljala svojevrstna oblika hierarhije glede na vrsto turistov oz. obiskovalcev (gledalcev), odvisna od tega, kje so se srečevali, do tega, kaj so počeli.

Za srednji vek so značilni prevlada cerkve in cerkvenih doktrin ter pozaba in razvrednotenje vseh pridobitev stare Grčije in Rima. Temu sledijo hude bolezni (kuga in kolera) in vsa temačnost srednjega veka (ang. Dark Ages), ki je zaznamovala značilne splošne družbene razmere (revščina) in nevarnosti (roparji in slaba cestna infrastruktura) ob poteh, zato so bili motivi potovanj $\mathrm{v}$ teh časih predvsem trgovski ali verski. Romarska središča so bila Jeruzalem, Rim in Santiago de Campostela. Cerkev je imela zelo velik vpliv v družbi in uveljavilo se je praznovanje verskih praznikov (ang. holy days), od koder beseda holiday (praznik, dopust, počitnice). Prav tako so v teh časih prirejali različne sejme, kjer je bila v ospredju družabnost za širše ljudstvo. Predstavniki visokega družbenega sloja so pogosto preživljali prosti čas na lovu, organiziranih plesih, ženske pa 
predvsem ob ročnem delu. Tudi v tem zgodovinskem obdobju je značilna diferenciacija prostočasnih aktivnosti glede na različne družbene sloje.

Renesansa in humanizem $s$ pričetkom v i 4. stoletju kot kulturno gibanje na prehodu iz starega $\mathrm{v}$ novi vek postavita nove temelje $\mathrm{v}$ umetnosti, znanosti in družbi nasploh. $\mathrm{V}$ tistem obdobju se omehčajo verskespone srednjega veka in med prostočasne aktivnosti se vse bolj uvrščajo glasba, drama in ples. Obdobje je zaznamovano $\mathrm{z}$ razcvetom umetnosti, kulture in znanosti na čelu z ustvarjalci tistega časa, kot so Michelangelo, Shakespeare, Cervantes, Leonardo da Vinci in drugi. V obdobju humanizma se na vseh področjih časti človeka, razvoj družbe, širjenja obzorij, pa tudi potovanja. Ob koncu tega obdobja, v i6. stoletju, se pojavi protestantska reformacija, z njo pa protestantizem in protestantska delovna eti$\mathrm{ka}$. Slednja je za koncept prostega časa izjemnega pomena, saj gre za ideologijo, ki zavrača in obsoja pojav zabave željnega plemstva. Protestantska delovna etika temelji na prepričanju, da je le trdo delo posameznika bogu všečno ravnanje in posamezniku omogoča odrešitev v onostranstvu, posledično pa ga vodi k osebnem uspehu in družbenem priznanju. S tem se sprejemljivost prostega časa v družbi spet nekoliko zatre. Delovna etika je imela velik vpliv tudi pozneje, v obdobju industrijske revolucije, zlasti zaradi protestantskih držav, kjer se je sprva začela.

Obdobje v razvoju turizma in turističnih atrakcij, imenovano potovanja Grand Tour, povezujemo z obdobjem šestnajstega in sedemnajstega stoletja, ko je angleška kraljica Elizabeta r. spodbujala potovanja mladih aristokratov po Evropi zaradi spoznavanja klasične kulture in umetnosti. Taka potovanja so bila rafinirana oblika izobraževanja, ki so je bili deležni mladi aristokrati, s potovanjem v kulturne prestolnice takratne Evrope. $S$ takim potovanjem so si pridobili neposredno izkušnjo zgodovine klasičnih civilizacij, zato lahko rečemo, da je bilo potovanje vezano na širitev njihovih obzorij, del splošne kulture in družbene uveljavitve. Plemstvo je na tak način pridobilo znanje in izkušnje, nujne za svoj status (Holden, 2004). Tej zgodnji obliki potovanja pravimo tudi klasični Grand Tour, za katerega je značilno, da v povprečju traja tudi do 40 mesecev, predvsem pa sloni na čustveno nevtralni izkušnji potnika (ogledovanje galerij, umetnin, muzejev, spomenikov ipd.). Del takega potovanja je bilo tudi vodenje dnevnika, kamor je posameznik beležil svoje vtise, dogodke in zanimivosti na poti.

$\mathrm{V}$ i8. stoletju se je dostopnost tovrstnih potovanj povečevala skladno $\mathrm{z}$ družbenim in gospodarskim razvojem ter politično stabilnostjo $\mathrm{v}$ Evropi, zato med aristokracijo postanejo zelo popularna termalna zdravilišča (Baden-Baden, Buxton, Vichy), tudi zaradi krepitve zavedanja o 
pomenu zdravja. Treba pa je poudariti, da so pripadniki najvišjega družbenega sloja vedno težili k temu, da bi se jasno in razločno distancirali od pripadnikov nižjega sloja, kar je veljalo tudi za ta, prostočasni segment življenja, zato je bilo povsem logično pričakovati formiranje nove, drugačne oblike preživljanja prostega časa, ki bo dostopna samo njim. S povečevanjem števila ljudi, ki so potovali, je ekskluzivnost potovanj slabela, $s$ tem pa pojavljale nove oblike preživljanja prostega časa. Ni odveč omeniti, da se je s povečevanjem števila ljudi spremenil tudi osnovni namen potovanja Grand Tour, ki je s tem postalo užitek in ne več izobrazba. Torej, ko potovanje izgubi na resnosti in reputaciji, gre razvoj naprej skozi nove, bolj prefinjene oblike prostočasenja in potovanj. Potovanje iz zdravstvenih motivov je tako postalo »ekskluziva« visokega družbenega razreda. Tako so nastala tudi mondena letovišča in klimatska zdravilišča, pretežno ob obali Mediterana (predvsem v južni Franciji in severni Italiji). Poleg zdravstvenih motivov med aristokrati narašča interes za divjino in naravo nasploh (Alpe). Gore, soteske, slapovi in gozdovi postanejo prostor interesa za obiskovalce, ki slavijo pristnost in veličastnost narave. Romantika na prehodu iz osemnajstega v devetnajsto stoletje spodbudi čustveno intenzivno doživljanje sveta okrog posameznika, kar vpliva tudi na čustveno intenziteto sodobnejše oblike potovanja Grand Tour, ki mu zaradi tega rečemo romantični Grand Tour. Ta potovanja so bila zaradi bolj ših cestnih in varnostnih razmer bistveno krajša (do 4 mesece), predvsem pa jih je posameznik čustveno intenzivno doživel. Napredek družbe od konca sedemnajstega do devetnajstega stoletja se kaže v znanosti, umetnosti, kulturi in glasbi, zato se odnos posameznika (in družbe) do teh vsebin odločno spremeni. Sredi devetnajstega stoletja pa je imela odločilna in ključna tehnološka prelomnica, širitev železnice, izjemen vpliv na demokratizacijo potovanja.

Industrijska revolucija zagotovo predstavlja največjo prelomnico, ne samo za sodobni turizem, pač pa za družbo nasploh. V osnovi gre za prehod iz kmetijske v industrijsko proizvodnjo, čemur sledijo družbene, ekonomske, tehnološke in kulturne posledice. Obdobje se začne ob koncu osemnajstega stoletja v Angliji, z uvedbo mehanizacije v proizvodnjo volne in bombaža. Industrializacija se tako začne širiti tudi v drugih državah, sprva v Evropi, nato tudi po svetu.

To je obdobje v zgodovini človeštva, ko lahko govorimo o začetku organiziranega prostega časa, kar ima za razvoj turizma zelo velik pomen $s$ konceptualnega vidika. Kot je bilo že poudarjeno, je prosti čas pogoj za vsako turistično aktivnost, torej bi z zgodovinskega vidika razvoja turiz- 
ma lahko rekli, da je industrijska revolucija začrtala osnove turizma kot sodobnega družbenega pojava.

$Z$ industrializacijo se sproži kar nekaj temeljnih premikov v takratni družbi; to so urbanizacija, tehnološki razvoj, nastanek novega, delavskega družbenega razreda, širitev sodobnega transportnega sistema, železnice, in demokratizacija potovanja. Vse to oblikuje podobo turizma, kot ga poznamo danes. Urbanizacija je proces preseljevanja prebivalstva s podeželja, kjer je kmetijstvo glavna dejavnost, v mestna središča, kjer pa se gradijo industrijska poslopja in tovarne, ki zaposlujejo delovno silo. Za ilustracijo, kako dramatična je bila ta sprememba, služi podatek, da je leta I 80 I v Angliji v mestih živelo le $20 \%$ prebivalstva, leta I90 pa že $80 \%$ (Urry, 2005). Ta sprememba se ne kaže samo v številu ljudi, ki živijo v mestih, temveč zlasti v načinu njihovega življenja, ki se drastično spremeni. Spremembo načina življenja skozi drugačen koncept pojmovanja časa lepo pojasnita Bramham in Wagg (2014). Pojmovanje časa je v obdobju pred tem vezano predvsem na naravne zakone - letne čase, ki določajo čas opravil na polju, čas dneva za delo, čas za sprostitev in druženje (ciklično dojemanje časa). Industrializacija pa pripelje do mehaničnega pojmovanja časa (linearno pojmovanje časa), ki je v tesni povezavi z načinom dela - stroji v tovarni, da bi bila učinkovita proizvodnja, morajo delati ves čas, neodvisno od vremenskih razmer ali letnega časa. Industrialci skrbijo za produktivnost, delavci pa jo dosegajo s trdim delom. Holden (2004, str. 25) meni, da je industrializacija sprožila ločitev človeka od narave. Zaradi dela $v$ tovarnah in produktivne naravnanosti industrialcev se poruši dnevni ritem življenja posameznika. Življenjske razmere delavcev so nehumane (70 ur dela, šest dni na teden in izjemno težke bivalne razmere), vse dokler izjemen sindikalni boj ne doseže skrajšanja urnika in se tudi delodajalci začnejo zavedati, da je produktivnost dela večja, če so delovne razmere in zdravje delavca boljši. Delavske pravice in razmere so v tem času nasploh zaznamovale sindikalno prizadevanje.

Industrijska revolucija je začrtala jasne meje med delom in prostim časom, česar v obdobju agrarne ureditve ni bilo (med delom so se ljudje družili in peli, počivali in podobno). $\mathrm{V}$ industrijski dobi je bilo delo zaznamovano tudi s prostorom, kjer je to potekalo (tovarna), izgubil pa se je pomen skupnosti in je bil posameznik prepuščen sebi in novim življenjskim razmeram. Prične se namreč pojav t. i. individualizacije, ki je dosegla svoj vrhunec v postindustrijski dobi oz. dobi postmoderne. Mesta so se zaradi urbanizacije gradila zelo hitro in nesistematično, zlasti za delovno silo so bile bivanjske razmere zelo slabe. Ločevanje dela od prostega časa je bilo vse očitnejše, kar je zaznamovalo tudi vedenje posameznika. 
Delo je zahtevalo resnost, disciplino in predanost, prosti čas pa je moral nujno ponuditi drugačne vidike življenja (počitek, sprostitev, zabavo). To je značilno tudi za razumevanje sodobnega turizma, kjer je domače okolje v opoziciji do počitnic, dopusta in potovanja.

$\mathrm{Z}$ naraščanjem produktivnosti in izjemnim ekonomskim razvojem so se krepile potrebe po turizmu in turističnih aktivnostih prebivalstva. Prihodek posameznika je zadoščal ne samo za primarne potrebe, pač pa tudi za prosti čas. Posledica tega in dejstva, da se $\mathrm{v}$ tem obdobju začne zelo hitro širiti nova oblika učinkovitega transporta, dostopna večjemu številu ljudi (železnica), je razvoj turizma, kot ga v osnovi poznamo danes. Za tako turistično vedenje in aktivnosti sta ob drugih družbenih in ekonomskih pogojih ključnega pomena čas in denar, ki sta na razpolago posamezniku. Ko delavci namenijo del svojega prihodka in časa za prostočasno aktivnost (potovanje), se $\mathrm{v}$ industrializirani Evropi in ZDA začneta angažirati moderna zabavna industrija in industrija prostega časa, da bi ustregli njihovim potrebam. Sprva ı 8-urne delovnike se skrajša na 9-urne ob uvedbi proste sobote in nedelje, poleg obstoječih, dela prostih praznikov. To je čas, ki ga lahko delavci preživijo stran od delovnega vsakdana, kar se začne uveljavljati kot »weekend «-počitnice - krajše potovanje ob koncu tedna na obalo ali preprosto v drugi kraj. Takšne počitnice predstavljajo začetek organiziranega prostega časa, kot ga poznamo danes. Trend takšnega preživljanja prostega časa se razširi po Evropi in Severni Ameriki. Družba začne prepoznavati koristi prostega časa, ki se jih regulira z zakonodajo in s predpisi o plačanem dopustu.

Tehnološki razvoj, spodbujen z odkritjem parnega stroja, je pripomogel $\mathrm{k}$ razvoju železnice in parnika, kot prvih dveh oblik transportnih sredstev za prevoz velikega števila potnikov. Prva množična potovanja ljudi so bila vezana na parnik ali vlak, zato je njuna pridobitev in dostopnost na tej točki pripomogla k razvoju turizma, kot ga poznamo danes. Iz tega razloga se številni avtorji strinjajo, da je bil njun prispevek k razvoju turizma največja med inovacijami industrijske revolucije.

Prva železniška povezava za potniški promet je bila odprta leta I 830 med Londonom in Manchestrom v Angliji (Holden, 2004). Thomas Cook je prepoznal potencial novih družbenih, gospodarskih in tehnoloških razmer ter leta I84I organiziral prvo paketno turistično potovanje. Prav tako je »popeljal« veliko število obiskovalcev na otvoritev prve Svetovne razstave v Londonu leta 185 I, ko je bila odprta Kristalna palača. Nato so sledile še druge Svetovne razstave, za katere je redno organiziral turistična potovanja. Ena najimenitnejših je Svetovna razstava leta i $898 \mathrm{v}$ Parizu, zaradi katere je bil zgrajen znameniti Eifflov stolp. Pomen Svetov- 
nih razstav je bil za razvoj turizma takrat (kot je še danes) izjemen, kajti postanejo evropska stalnica, ki vključuje potovanje, druženje, kulturo, umetnost - skratka, družabni dogodek, ki slavi tehnološki in gospodarski napredek narodov. Pri tem je treba omeniti strukturo ciljne publike, ki ji je bilo po večini namenjeno potovanje. Večinoma je šlo za srednji in delavski razred, saj se buržoazija ni zanimala za paketne aranžmaje.

Nedvomno je industrijska revolucija sprožila val demokratizacije potovanj, zahvaljujoč vsem družbenim, tehnološkim in gospodarskim spremembam. Tako sta se spremenila način življenja kot tudi način preživljanja prostega časa in potovanja. Dostopnost potovanja večjemu številu ljudi (višji srednji razred in delavski razred imata sredstva in čas za potovanje) in mobilnost zaradi učinkovitih transportnih rešitev (vlak, parnik), ob družbenih in gospodarskih spremembah, omogočita prvo demokratizacijo potovanja in začetek sodobnega turizma. Lahko bi rekli, da se je s hitrostjo napredka družbe proporcionalno povečala hitrost in pogostost potovanj ljudi v prostem času. Če bi želeli na kratko izpostaviti prispevek industrijske revolucije $\mathrm{k}$ obravnavani tematiki, bi lahko navedli sledeče:

- Industrijska revolucija je omogočila prosti čas in ga naredila za sprejemljivega v družbi, zlasti med pripadniki delavskega razreda.

- Sprožila je formalno delitev prostega od delovnega časa in poudarila njegov prispevek $\mathrm{k}$ produktivnosti dela.

- Sprožila je višjo storilnost (stroji, ljudje, tehnologija) in s tem potrebo po kakovostnejšem življenju.

- Prispevala je k organiziranosti prostočasnih dejavnosti (ponudba) in razvoju industrije prostega časa.

- Prispevala je k premiku od industrijske dobe proti storitvenim dejavnostim in mnogo kasneje $\mathrm{k}$ informacijski dobi.

- V določeni meri je omogočila kakovostnejše in bogatejše življenje posameznika in družbe.

Lahko sklenemo, da je industrijska revolucija prispevala k premiku od delovne etike do etike prostega časa. Ta premik je potekal z gospodarskim, tehnološkim in družbeno-kulturnim razvojem ter napredkom in krepil potrebo človeka po samoaktualizaciji. Kakovost življenja ljudi se z ekonomskim in tehnološkim razvojem izboljšuje, delovne in življenjske razmere prav tako, podalǰ̌uje se življenjska doba zaradi boljšega zdravstvenega sistema in vse bolj uveljavljenih človekovih pravic. Prosti čas kot del kakovostnega življenja posameznika postaja njegova odgovornost, potre- 
ba in pravica. Tako je učinek človeka (delavca) v družbi in ekonomiji še večji in je koristnost prostega časa conditio sine qua non. Zavedanje družbe o koristih prostega časa $v$ tem obdobju odločno narašča. Etika prostega časa tako prevzema prvenstvo v vrednostnem sistemu družbe. Etika in estetika prostega časa sta pomembni kategoriji takratne družbe, kar se kaže na vseh njenih področjih. $Z$ ekonomsko blaginjo in drugimi pogoji (tehnološkimi, varnostnimi, infrastrukturnimi ipd.) je turizem postal sestavni del globalne družbe.

Na sliki 2 prikazujemo »krog sprememb « v družbi, ki so vplivale na formalizacijo prostega časa ter pojav turističnih potovanj $\mathrm{v}$ povezavi $s$ turističnimi atrakcijami, ki pa so glavni motiv vsakega turističnega obiska. $\mathrm{Z}$ naraščanjem obsega prostega časa se povečuje obseg turističnih potovanj, ker družbene in druge razmere povečujejo kakovost življenja ljudi, $s$ tem pa narašča potreba po samoaktualizaciji in potreba po turistični aktivnosti. Turizem tako postaja neločljiv od družbe in posameznika, tako kot je danes; ni šlo torej za »modno muho«, pač pa družbeno in gospodarsko pogojen fenomen, ki »vztraja «̌ še danes.

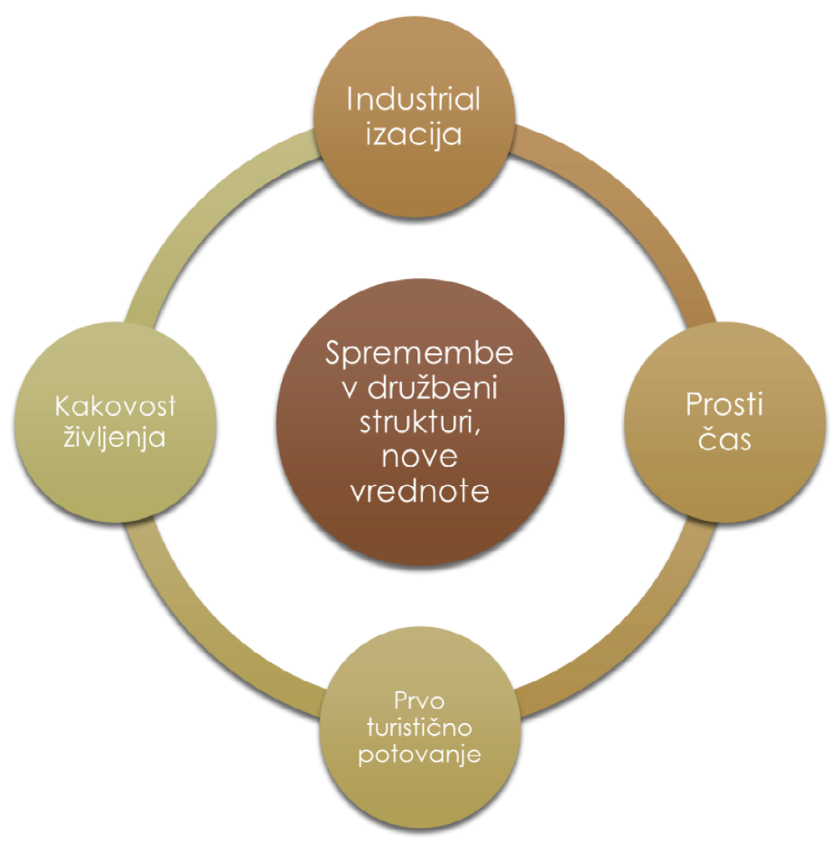

Slika 2: Krog sprememb v družbi in turizem 
V zgodnjem dvajsetem stoletju se je s prvo svetovno vojno prekinilo dolgo obdobje, bolj znano pod imenom La Belle Époque. To je bil čas v evropski zgodovini, ko so se izjemno razvijale umetnost, kultura in tehnologija, čas splošnega miru in blaginje. Take razmere so spodbujale potovanja in razvoj turizma. Čas med obema vojnama je bil prekratek, da bi se dodobra razmahnil nov val razvoja turizma, zato se je to zgodilo šele po drugi svetovni vojni, natančneje, po letu i950.

Množični turizem se je v povojni Evropi razmahnil kot posledica povojnega miru in izjemnega gospodarskega razvoja, ki se je dogajal od poznih 5o-tih let. $\mathrm{K}$ množičnosti potovanj je zlasti prispevala nova oblika množičnega letalskega prevoza - čarterski poleti iz zahodne Evrope v Mediteran. Ekonomski razvoj v družbi povojne Evrope in Severne Amerike vpliva na izboljšanje splošnih razmer, zlasti na področju kakovosti življenja. $S$ tem naraščajo tudi nove in kompleksnejše potrebe turistov. Predvsem na podlagi potovalnih izkušenj, ki jih pridobivajo, se čedalje bolj krepi raznovrstnost potreb na turističnem potovanju. Pričakovanja na turističnem potovanju in turistična doživetja postajajo vse kompleksnejša in zato je kompleksnejša tudi turistična ponudba. Slednja mora biti na turistični destinaciji raznovrstna, bogata in vsebinsko smiselno povezana. Le tako lahko omogoča celovito turistično doživetje, ki ga pričakuje sodobni turist (Vodeb, 2014, str. 4).

Množični turizem je logična posledica razmer takratnega časa in stanja v družbi. Končala se je druga svetovna vojna in družba je bila potrebna miru. Po dolgem času se je življenje normaliziralo in v povojni obnovi se je krepilo navdušenje človeka novega obdobja. To novo obdobje je prineslo ponovni ekonomski zagon družbe, v kateri se poleg osnovnih potreb človeka ustvarjajo nove potrebe. Ena od teh potreb je potreba po potovanju - turističnem potovanju. Leta 1948 so Združeni narodi objavili Deklaracijo o človekovih pravicah in v 24. členu je zapisano: >Vsakdo ima pravico do počitka in prostega časa, vključno z razumno omejitvijo delovnih ur, in pravico do občasnega plačanega dopusta.«

$Z$ razvojem obmorskih turističnih krajev v Sredozemlju se razvijejo tipični primeri množičnega turizma v Italiji, Grčiji in Španiji. Ljudje odhajajo na počitnice $v$ tople kraje, njihova pričakovanja o počitnicah pa so dokaj skromna. Skromna pričakovanja in preproste potrebe so posledica odsotnosti potovalnih izkušenj, ki niso vezane le na izkušnjo fizičnega, realnega potovanja. Številni ljudje, ki do takrat niso nikamor potovali, predstavljajo potencial turističnega povpraševanja, dokaj neobčutljivega za drugo kulturo in kraj potovanja (Vodeb, 20 I 4, str. 5). Po so. letu prejšnjega stoletja se začne nov način turističnih potovanj in preživljanja pros- 
tega časa. Ta so dostopna večjemu številu ekonomsko aktivnih ljudi, ki svobodno razpolagajo s svojimi sredstvi in časom ter pri tem ne zahtevajo veliko. $\mathrm{V}$ prid temu so (vsaj do I. naftne krize) poceni letalski prevoz, poceni paketni aranžmaji ter delovanje na strani ponudbe po principu ekonomije obsega. Zaradi odsotnosti izkušnje o nenačrtovanem ali stihijskem turističnem razvoju ter kratkoročnih vizij spričo hitrih ekonomskih učinkov, deviznega priliva in zaposlitvene funkcije turizma se razvoj turizma prevesi v koncept, ki se mu na podlagi današnjih izkušenj ter predvidenih posledic družba želi izogniti. Množični turizem ima tako negativen prizvok, slabšalni pomen in je pokazatelj stanja in stopnje zavesti v družbi, ki opozarja na neželene posledice (Vodeb, 20I4, str. 6).

V tabeli I prikazujemo značilnosti množičnega turista in množičnega turizma, ki oblikujejo značilne vrste turističnih atrakcij tega obdobja. Turistično gospodarstvo je pretežno skoncentrirano na ekonomske učinke, hiter razvoj ter zaposlitveno in devizno funkcijo turizma. Izjemno je pomembna produktna naravnanost turističnega gospodarstva, ki pa ni trajnostno naravnana. Na turizem se gleda kot na »rešilno bilko « v gospodarskem razvoju neke regije ali kraja in se mu pripisuje zgolj gospodarsko vlogo. Na drugi strani pa ima nezahteven, neselektiven in neizkušen turist dostop in možnost turističnega gibanja zaradi ugodnih počitniških aranžmajev, novih načinov plačila in tehnologije v transportu.

Tabela I: Značilnosti množičnega turizma in turista

\begin{tabular}{|c|c|}
\hline Množični turist & Turistično gospodarstvo \\
\hline Razvojna stopnja družbe & Visoki ekonomski učinki \\
\hline Po 5o. letu 20.st & Hiter razvoj - hiter zaslužek \\
\hline Čarterski poleti (razvoj letalske industrije, poceni nafta) & Nenačrtovan razvoj (veliki hoteli, veliko število turistov) \\
\hline Poceni počitnice (kreditne kartice, paketni aranžmaji) & $\begin{array}{l}\text { Zaposlovanje velikega števila ljudi (zaposlitvena funk- } \\
\text { cija turizma) }\end{array}$ \\
\hline Dostopnost počitnic (prosti čas in sredstva) & Devizni priliv (devizna funkcija turizma) \\
\hline Nezahteven gost (koncept morje in sonce) & $\begin{array}{l}\text { Kratkoročna orientacija - netrajnostni koncept (vzorec } \\
\text { povečevanja) }\end{array}$ \\
\hline $\begin{array}{l}\text { Rutinsko konzumiranje počitnic (generacija baby } \\
\text { boom) }\end{array}$ & Visoka produktivnost (visoki dobički) \\
\hline
\end{tabular}

Vir: Prirejeno po Vodeb, 2014.

Vsa zgodovinska obdobja in prelomnice $\mathrm{v}$ razvoju turističnih atrakcij obravnavamo v družbenem, ekonomskem in tehnološkem kontekstu. 
Kontekstualna obravnava teh kategorij je nujna za pravilno razumevanje in interpretacijo vzrokov ter posledic dogodkov, ki so oblikovali značilnosti turističnih atrakcij.

Naraščanje števila atrakcij in obiskovalcev po letu 1950 nedvomno prispeva k demokratizaciji potovanj, ki pa ga $\mathrm{v} 20$. stoletju obravnavamo skozi razvoj množičnega turizma. Ta svoj vrhunec doseže med letoma 1970 in $1980 . \mathrm{V}$ ospredje čedalje bolj prihajajo postindustrijske vrednote, ki se kažejo v tem, da narašča delež prostega časa, razvija se sektor storitev, prihaja do decentraliziranja proizvodnje, mobilnost postaja nuja, krepi se ekološka etika, širijo in razvijajo se elektronski mediji, globalizacija zajame ves svet in človeška družba je $\mathrm{v}$ nenehnem gibanju. Turistična atrakcija tako postaja, se obravnava in trži kot turistični proizvod. Lahko bi sklenili, da sta zanimanje za potovanja in obisk atrakcij v korelaciji.

V kontekstu zgodovinskega pregleda razvoja turističnih atrakcij sta dve ključni kategoriji ali skupna imenovalca vsem spremembam in prelomnicam. To sta:

- pomen, ki ga turističnim atrakcijam in potovanju pripisuje družba, ter

- dostopnost oz. razpoložljivost (prostega časa, sredstev, zanimanja).

Pomen, ki ga družba pripisuje atrakcijam ali turizmu nasploh, nedvomno vpliva na njegov razvoj in razširjenost. Naklonjenost družbe prostemu času izjemno spodbudi njegov razvoj, kar je evidentno od industrijske revolucije naprej. Dostopnost in razpolaganje s prostim časom in sredstvi pa sta dva kritična momenta v razvoju turizma, ki ju je ob tehnološkem razvoju (železnica) prepoznal Thomas Cook in organiziral prvo turistično potovanje $\mathrm{z}$ vlakom. Pri vsem tem pa ne gre mimo dejstva, da je nujno razumevanje motivov za obisk, kajti atrakcije so družbeni fenomen in zahtevajo razumevanje vedenja obiskovalcev (Austin, 2002; Poria idr., 2006). Razumevanje vedenja obiskovalcev je poglavitna tema zanimanja menedžmenta turističnih atrakcij vsled potreb po učinkovitem in uspešnem upravljanju, zaradi česar jo bomo osvetlili v poglavju o upravljanju atrakcij. 


\section{Razvrščanje atrakcij}

O pomenu turističnih atrakcij za turizem je bilo govora $\mathrm{v}$ predhodnih poglavjih tega dela. V slednjem smo obravnavali vlogo in pomen turističnih atrakcij skozi zgodovinska obdobja. V tem poglavju prehajamo na klasifikacijo ali razvrščanje atrakcij.

Načinov razvrščanja je veliko, kot je veliko avtorjev, številni poskusi razvrščanja atrakcij pa temeljijo na binarnem principu, ki atrakcije generalno deli po poreklu, in sicer na naravne in ustvarjene. Ta delitev je po mnenju avtorice A. Leask (2008) presplošna, preozka in enodimenzionalna, kar je v nasprotju z večdimenzionalnostjo in kompleksnostjo turističnih atrakcij in ima po njenem mnenju lahko negativne posledice na upravljanje atrakcij.

Glede na različne vidike obravnave je Lew (1987), na podlagi analize znanstvenih študij, ki obravnavajo atrakcije, oblikoval tri glavna izhodišča pri razvrščanju turističnih atrakcij. To so (Lew, 1987, str. 554-56I):

- ideografski vidik (opis atrakcij, njenih lastnosti, glavnih atributov),

- organizacijski in razvojni vidik (prostor, čas, kapacitete, okolje) in

- kognitivni vidik (izkušnje, percepcije, doživetja).

Če sežemo globje v razumevanje teh treh vidikov, kot izhodišč za klasifikacijo ali razvrščanje atrakcij, lahko ideografski vidik povežemo $s$ konkretno edinstvenostjo atrakcije, vezano na njene osnovne lastnosti, po katerih se lahko loči od drugih ali se z njimi primerja. Ta je v končni fazi povezana $z$ imenom atrakcije, saj njeno ime odraža to edinstvenost in 
tipičnost. Ideografski vidik razvrščanja torej temelji na neki materialni, oprijemljivi lastnosti atrakcije in je največkrat uporabljen pri razvrščanju atrakcij v literaturi.

Organizacijski vidik razvrščanja se osredotoča na prostorske, časovne ali zmogljivostne značilnosti atrakcije, ki pa so v direktni povezavi z načrtovanjem in marketingom turizma. Zelo je pomemben prostor, kjer se atrakcija nahaja. Nenazadnje jo ta prostor opredeljuje, določa njeno velikost, povezanost in odnos z drugimi atrakcijami ter destinacijo. Prostor omogoča mobilnost in dostopnost do destinacije, kar je ključnega pomena za njeno delovanje in obstoj. $S$ prostorsko dimenzijo je povezana tudi zmogljivost atrakcije $v$ fizičnem smislu. Fizična zmogljivost atrakcije je vezana na njeno infrastrukturo, turistično ponudbo in storitve. Velikokrat je zmogljivost atrakcije potrebno spremljati glede na sezone, saj se lahko glede na priljubljenost, motive ali vsebino kažejo razlike v koncentraciji obiska na letni ravni.

Kognitivni vidik razvrščanja atrakcij temelji na percepciji obiskovalcev in turistov, njihovih zaznavah, izkušnjah in doživetjih v povezavi $\mathrm{z}$ atrakcijo. Tukaj je treba poudariti aktivno vlogo turista $\mathrm{v}$ povezavi $\mathrm{z}$ atrakcijo kot predmetom turistične konzumacije - potrošnje. Za razliko od drugih gospodarskih dobrin turistična atrakcija angažira vse čute obiskovalca, tako jo aktivno sodeluje in (so)ustvarja s svojo aktivno vlogo doživljanja. Ne gre le za pasivno konzumacijo ponujenega blaga na prodajni polici.

Glede na dejstvo, da so turistični viri osnova za nastanek turistične atrakcije, je tudi njihovo razvrščanje vezano na generalno delitev virov po poreklu. Po poreklu vire delimo na dve osnovni skupini. Prva skupina predstavlja naravne ali biotopne vire. To so podnebni, geografski, hidrografski, biogeografski in pokrajinski viri. Druga skupina predstavlja antropološke ali atropične vire, ki jih je ustvaril človek. To so kulturno-zgodovinski, etnosocialni, prireditveni, umetniški in ambientalni viri (Vodeb, 2014, str. 31).

V nadaljevanju sledi opis vrste različnih načinov razvrščanja turističnih virov oz. privlačnosti, ki jih obravnavamo v širšem okvirju destinacije. Vire lahko razdelimo v tri skupine (Vodeb, 20I4):

I. temeljni turistični viri so potencialne in realne privlačnosti destinacije (za destinacijo so najpomembnejši, ker privabljajo obiskovalce oz. so motiv obiska);

2. drugi direktni turistični viri so objekti na destinaciji (hoteli, dopolnilne dejavnosti, kadri - osebje, potovalne agencije, turistične skupnosti, informacije in promocijski material). Ta skupina 
virov obiskovalcem zagotavlja udobnost bivanja in različne aktivnosti;

3. indirektni turistični viri predstavljajo ohranjeno okolje, geoprometni položaj, prometno povezanost, komunalno infrastrukturo, kakovost prostorske organizacije, politično stabilnost itn.

Naslednja delitev zajema dve skupini virov (Vodeb, 2014):

I. primarni viri obsegajo tiste dobrine, ki niso proizvod dela ali ki jih človek ne more več proizvajati v enaki kakovosti in z enako uporabno vrednostjo. Sem prištevamo podnebje, ekologijo, kulturo, tradicionalno arhitekturo in pejsaž;

2. sekundarni viri zajemajo tiste turistične dobrine, ki so proizvod dela in ki jih človek ob drugih nespremenjenih pogojih še vedno lahko proizvaja v zahtevani količini in kakovosti. Sem prištevamo vsebine, razvite prav za turizem (hoteli, restavracije, transport, športno-rekreacijske vsebine in infrastrukturo).

Zavedati se je treba, da različni pristopi razvrščanja atrakcij vplivajo na različne pristope pri upravljanju atrakcij. Npr., naravne atrakcije ponavadi zahtevajo manj zaposlenih, nižje fiksne stroške obratovanja in bolj odprto dostopnost kot zgrajene atrakcije. To seveda ne pomeni, da je pomen upravljanja naravnih atrakcij manjši od pomena upravljanja zgrajenih atrakcij. Gre samo za različne cilje menedžmenta glede na vrsto atrakcije in njen namen (Leask, 2008, str. 5).

Ritchie in Crouch (2003) predlagata delitev turističnih privlačnosti v sedem skupin. Teh sedem skupin po njunem zahteva ustrezno marketinško obravnavo in pristop.

I. Pokrajina in podnebje delujeta na vizualne in čutne užitke obiskovalcev.

$\mathrm{Z}$ vidika turističnega menedžmenta je ironično dejstvo, da so naravni viri najpomembnejši dejavniki konkurenčnosti destinacije, saj so v večini nespremenljivi oz. na njihovo količino in obliko nimamo velikega vpliva. Glede kakovosti teh virov pa je nekoliko drugače. Kakovost naravnih virov je zelo odvisna od turističnega menedžmenta, sodelovanja z drugimi sektorji in ohranjanja kakovosti teh virov. Povezave in medsebojna odvisnost atrakcij in drugih sektorjev vpliva na medsebojne koristi in interese za sodelovanje med njimi. Dolgoročno s tem vplivamo tudi na količino naravnih virov.

Destinacije, ki so obdarjene z naravnimi viri, v sodobnem času visoke onesnaženosti in prenaseljenosti postajajo zelo privlačne. Privlačnost des- 
tinacije, ki temelji na njenih naravnih virih, postaja pomembna, zato ne preseneča, da se turizem pojavlja v naravnih območjih ( $>$ natural area tourism «), in sicer kot pustolovski, naravni turizem, turizem v divjini in ekoturizem. Takšne destinacije svoje konkurenčne prednosti navadno gradijo na naravnih virih, s katerimi razpolagajo (Vodeb, 2014, str. 32).

Destinacije, ki nimajo ugodnega podnebja ali čudovite pokrajine, imajo dve možnosti: prilagoditi se ponudbi s svojimi skromnimi viri ali pa se osredotočiti na tiste (manjše) segmente turistov, ki jih privablja prav nasprotje konvencionalnim virom (Antarktika, džungla ob Amazonki, itn.).

2. Kultura in zgodovina destinacije ponujata obiskovalcu intelektualno zadovoljstvo.

Kultura na splošno ima v dimenziji privlačnosti destinacije drugi najmočnejši vpliv. Elementi kulture torej lahko predstavljajo turistično privlačnost neke destinacije. Ti elementi so jezik, tradicija, kulinarika, umetnost, rokodelstvo in glasba, zgodovina, tehnologija, arhitektura, religija, izobraževanje, prostočasne dejavnosti kot način življenja. Zavedati se je treba, da domače prebivalstvo in obiskovalci nimajo enake zaznave posameznih elementov kulture destinacije. Obe skupini udeležencev na destinaciji posameznim elementom kulture pravzaprav pripisujeta različen pomen (Ritchie in Zins, 1978). Tako so npr. za domačine prvi trije elementi kulture prostočasne aktivnosti, kulinarika in tradicija, obiskovalci pa na prvo mesto postavijo tradicijo, tej na drugem mestu sledi kulinarika, na tretjem mestu pa zgodovina.

Način doživljanja kulture destinacije pa je seveda odvisen tudi od kulture obiskovalcev samih. Destinacijski menedžment se mora pri oblikovanju turistične ponudbe zavedati, da je način predstavljanja kulturnih virov zato zelo pomemben, hkrati pa mora razumeti psihologijo ter kulturno ozadje, iz katerega segment turistov prihaja (Vodeb, 2014, str. 33).

3. Mešanica aktivnosti ponuja fizične in čustvene spodbude za obiskovalce.

Pomen pestre in razgibane ponudbe aktivnosti na destinaciji, ki posameznemu obiskovalcu ostanejo v spominu, je zelo pomemben. Pri tem gre vedno za mešanico aktivnosti, združenih po vsebinah, ki pa morajo biti usklajene z vrsto destinacije, vrednotami domačega prebivalstva, zakonodajo in s pravili lokalne skupnosti. Ponujene aktivnosti se morajo med seboj dopolnjevati in predstavljati edinstveno ponudbo destinacije. Ta edinstvenost omogoča prepoznavnost v očeh obiskovalcev ter konku- 
renčnost na turističnem trgu. Idealno je, če zagotovimo mešanico aktivnosti skozi celo leto, da se izognemo problemu sezonskosti.

4. Posebni dogodki ustvarjajo dinamiko in edinstvenost destinacije ter oblikujejo njeno identiteto.

Če ima destinacija »prirojene« komparativne prednosti (npr. Pariz, Rim, Veliki kanjon), je lažje graditi konkurenčno prednost, kot če mora inovativno osnovo za tako prednost zgraditi sama. Olimpijske igre, svetovna prvenstva in svetovne razstave so »megadogodki" in predstavljajo priložnost za »prihod iz sence« ter oblikovanje podobe destinacije v očeh potencialnih turistov. Menedžment destinacije je tisti, ki v percepciji turistov oblikuje vrednost dogodka. Nekatere take destinacije prerastejo v destinacije $\gg$ must-see $\ll$.

Med enkratnimi in ponavljajočimi se dogodki obstaja velika razlika. Pri slednjih ima destinacijski menedžment možnost postopoma graditi destinacijo - njeno podobo, prepoznavnost in vrednost v očeh turistov. Primer takih destinacij sta teniški turnir v Wimbledonu in Oktoberfest v Münchnu (Vodeb, 2014, str. 34).

5. Zabava - v nekaterih destinacijah je ključni motiv prihoda turistov moč posameznih zabavnih prireditev.

London, New York in Pariz so destinacije, za katere je ključna turistična privlačnost zabava. Las Vegas je iz puščave zgrajena zabaviščna meka, kjer je poleg igralništva ključna turistična privlačnost zabava. Disneyland je prav tako primer destinacije, ki temelji na zabavi. Zanimivo je, da takšna oblika zabave v Evropi ni tako razširjena ali priljubljena. Razlogi izvirajo iz socio-kulturnih razlik med Američani in Evropejci (Vodeb, 2014).

\section{Določeni elementi superstrukture}

Turistična superstruktura ali nadstruktura je opredeljena kot zgradba ali oprema, ki je primarno namenjena potrebam ali interesom turistov. V veliki večini gre za zgradbe, ki so primarno namenjene turizmu, so pa tudi takšne, ki so prvotno služile drugim namenom. Najpogostejši primeri turistične nadstrukture so hoteli, restavracije, turistični informativni centri ipd. Ločujemo tri vrste turistične nadstrukture: funkcionalne elemente, dopolnilne izgrajene elemente in dopolnilne naravne elemente (Ritchie in Crouch, 2003, 126).

Funkcionalni elementi predstavljajo različne skupine nastanitvenih kapacitet (hoteli, penzioni, restavracije itn.), letališča, tematski parki, pristanišča, kongresni centri ipd. Dopolnilni izgrajeni elementi so muzeji, 
živalski vrtovi, trgovsko-poslovna poslopja, športni in olimpijski stadioni, domovi slavnih ljudi, vesoljski centri ipd. Dopolnilni naravni elementi so cerkve, katedrale, naravne znamenitosti, zgodovinske točke, edinstvena industrijska ali arhitekturna mesta, univerze in mesta naravnih nesreč.

Nekateri primeri turistične nadstrukture so tako edinstveni, da pravzaprav predstavljajo turistično privlačnost samo. $V$ to skupino lahko štejemo Eifflov stolp v Franciji, Poševni stolp v Pisi v Italiji, Empire State Building in Kip svobode v New Yorku, Golden Gate Bridge v San Franciscu, Sydneysko operno hišo v Avstraliji, Kitajski zid, Parthenon v Atenah, Tadž Mahal v Indiji.

Nekatere zgradbe ali kompleksi so zaradi arhitekturnih značilnosti, vsebine ali kakšne druge edinstvenosti postali privlačnosti, ki jih je treba obiskati. Zelo znani taki primeri so muzej Louvre v Parizu, muzej Hermitage v St Petersburgu, cerkev La Sagrada Familia v Barceloni, bazilika sv. Petra v Rimu ipd. (Vodeb, 2014, str. 35).

\section{Tržne vezi predstavljajo področje človeških odnosov.}

Kljub veličastnim privlačnostim destinacij, zaradi katerih so izbrane kot potovalni cilji številnih turistov, obstajajo tudi manj očitne privlačnosti, ki ljudi spodbujajo k obiskovanju destinacij, ki jih sicer ne bi izbrali. Tržne vezi lahko ločimo na poslovne in osebne. Izziv, $s$ katerim se sooča destinacijski menedžment, ni samo identifikacija posameznikov, na katerih te tržne vezi lahko uporablja, ampak tudi ugotovitev, kako jih lahko uporabi za spodbujanje, olajšanje in usmerjanje povpraševanja v destinaciji.

Med osebnimi vezmi na prvo mesto postavljamo družinske in prijateljske vezi. Vpliv destinacijskega menedžmenta pri teh vezeh je seveda zelo šibak, razen v primerih, ko destinacija spodbuja dogodke tipa družinskih (generacijskih) srečanj, obletnic in osebnih jubilejev družinskih članov. Na drugem mestu so osebne vezi, vezane na religijo. Za nekatere religije je značilno obiskovanje določenih svetih mest, kot so Meka (za muslimane), Rim in bazilika sv. Petra (za katoličane) ter Jeruzalem (za jude, kristjane in muslimane). Ta mesta imajo $v$ omenjenih religijah poseben pomen in zato predstavljajo močan motiv za potovanje.

Naslednja podskupina osebnih vezi so etnične korenine, ki so po značilnostih zelo podobne religiji. Afroameričani obiskujejo afriška mesta, kjer so živeli njihovi predniki. Tudi potomci evropskih priseljencev v ZDA (npr. Poljaki, Madžari, Italijani, Francozi in Nemci) svoje korenine iščejo tudi tako, da vsaj enkrat v življenju obiščejo svojo pradomovino.

Tudi šport je ena od podvrst osebnih vezi z močnim motivacijskim nabojem, ki lahko sproži odločitev za obisk točno določene destinacije, in 
sicer zaradi lastnega športnega udejstvovanja (profesionalni, rekreativni, amaterski športniki) ali pa v družinskem spremstvu športnika.

Profesionalne vezi so področje lažjega vpliva destinacijskega menedžmenta kot v primeru osebnih vezi. Ponujajo namreč več priložnosti za spodbujanje in vplivanje na odločitve, povezane s potovanji. Konference, simpoziji in kongresi so priložnosti za poslovna srečanja, izmenjavo izkušenj in poslovna poznanstva. Organizatorji in ponudniki tovrstnih storitev določajo prostor in čas dogodka. Podobna podvrsta poslovnih vezi je izobraževanje. Študenti, ki študirajo v tujini ali so na mednarodni izmenjavi, ustvarjajo povezave in odnose, ki so velikokrat osnova za potovalna in turistična vedenja v prihodnje (Vodeb, 2014, str. 36-37).

Turistične privlačnosti lahko razvrščamo glede na to, ali je za njihov obisk potrebno plačati ali ne. Javne ustanove, kot so muzeji, so namenjene javnosti, zato se zastavlja vprašanje o tem, ali naj bodo zaradi tega obiski le-teh brezplačni. Z odločitvijo o tem, ali je za obisk atrakcije potrebno plačati, menedžment lahko dosega različne cilje, od izobraževalnih do poslovnih. Med drugim se lahko s cenami vstopnic dosega določen namen atrakcije (npr. širši izobraževalni cilji) oz. se z različnimi cenami vstopnin (npr. za otroke, seniorje; različne cene vstopnin glede na čas dneva ali leta ipd.) dosega zapolnjevanje manj frekventnih terminov.

Nadalje se turistične privlačnosti lahko razdeli glede na lastništvo. Lastnik je v tem primeru lahko država, neprofitne organizacije ali privatne organizacije. Ta delitev namreč izredno vpliva na upravljanje in odločitve menedžmenta, zlasti glede cen vstopnic, marketinga in razvoja turistične privlačnosti (Leask, 2008, str. 6). Lastništvo atrakcije je povezano tudi z vrsto atrakcije. Npr., nacionalni parki so najpogosteje v javni lasti, medtem ko so tematski parki navadno v zasebni lasti. Prostovoljne organizacije imajo navadno za cilj ohranjanje neke naravne ali zgrajene atrakcije in dobiček ni prioriteta njihovega delovanja.

Naslednji pristop pri razvrščanju atrakcij je glede na ciljni trg, ki ga atrakcija nagovarja. Lokalne ali regionalne atrakcije delujejo drugače od mednarodnih. Ta delitev namreč precej določa naravo upravljanja atrakcije, zlasti njeno cenovno politiko, dostopnost atrakcije (velikost trga), turistično potrošnjo in interpretacijo atrakcije. Ponavadi imajo nacionalne turistične organizacije voje sisteme razvrščanja atrakcij, tudi glede na pomen posamezne turistične atrakcije v celotnem turizmu destinacije. Tako za vsako državo (destinacijo) velja, da ima t. i. primarne atrakcije - najprepoznavnejše, $\mathrm{z}$ največ obiska, najprisotnejše v promocijskih materialih (t. i. paradni konj destinacije). 
Glede na prostorsko organizacijo in postavitev v prostoru lahko po Yalu (I99i) opredelimo naslednje vrste turističnih atrakcij:

- zunanje (vrtovi, arheološka najdišča) in notranje (zgodovinske zgradbe, muzeji, galerije ... ) privlačnosti;

- naravne (Bohinjsko jezero) in antropogene (Tower of London, Eifflov stolp) privlačnosti;

- povezane (Plečnikova dela v Ljubljani, Gaudi v Barceloni) in linearne (obala, riviera, tematske poti - disperzna).

Wall (1997) meni, da je od prostorskih lastnosti odvisno, kakšne so posledice prisotnosti in vedenja obiskovalcev, kakšni so pogoji za komercialni razvoj atrakcije in kakšne so lahko omejitve pri njenem načrtovanju in upravljanju.Omenja atrakcije, kot so:

- točka (na majhnem prostoru veliko število obiskovalcev, koncentracija omogoča poslovanje na osnovi »ekonomije obsega «);

- linija (tematske poti, obala, riviera - zgoščena ponudba, gneče);

- cona (narodni parki, zaščitena območja, omogoča disperzijo, manjša koncentracija ponudbe).

Atrakcije, kot je točka, so po njegovem skoncentrirane na manjšem geografskem prostoru, zaradi česar je večja možnost gneče, medtem ko atrakcije, kot je linija, vseeno do neke mere omogočajo disperzijo obiskovalcev. Cone po tej delitvi predstavljajo širši prostor atrakcije, ki omogoča največjo možno disperzijo obiskovalcev, zlasti tam, kjer je govora o zaščitenih območjih, ki imajo že zaradi tega predpisano nosilno zmogljivost (maksimalno število obiskovalcev, ki jih lahko sprejmejo naenkrat).

Glede na ta prostorski vzorec razvrščanja atrakcij je zanimiva še ena podskupina atrakcij, ki jih v literaturi najdemo pod imenom »periferne $\ll$ (Wanhill, 1997). Mislimo na atrakcije, ki so, geografsko gledano, periferni deli (najpogosteje obmejna območja) držav ali večjih regij in imajo zaradi tega posebne lastnosti, ki pa so pogosto zanimive za obiskovalce. Veliko je primerov čezmejnih turističnih atrakcij (npr. Bodensko jezero, Niagarski slapovi, Iguacijski slapovi, Mednarodni vrt v Manitobi ipd.), ki zaradi svoje edinstvenosti in znamenitosti privabljajo veliko število obiskovalcev.

Ni odveč poudariti pomena sodelovanja in vključevanja lokalne skupnosti v procesu upravljanja turistične atrakcije, o čemer bo več govora $\mathrm{v}$ naslednjih poglavjih. Tudi njihove potrebe in pričakovanja je namreč potrebno zadovoljiti, da bi lahko atrakcija uspešno delovala. Prav tako je treba povezanost atrakcij z drugimi sektorji razumeti v luči vpliva, ki ga ima 
lahko turizem v povezavi z drugimi sektorji (zaposlitvena funkcija, turistični multiplikator, sinergijski učinki, gospodarski in regionalni razvoj ipd.).

Najbolj razširjena in sprejeta klasifikacija turističnih atrakcij v literaturi je Swarbrookova (2002) in po tej se privlačnosti deli na:

- naravne privlačnosti (plaže, jame, reke, jezera, gozdovi, skale ... );

- umetne, ki niso bile zgrajene za turiste (sakralni objekti, cerkve, katedrale, arheološka najdišča, spomeniki);

- umetne, zgrajene za turiste (tematski parki, zabaviščni parki, marine, vrtni centri, safari parki, terme, igralnice, vodni parki);

- posebne dogodke (trgi in sejmi, festivali, športni dogodki, verski dogodki).

Kot je razvidno iz zgornje razvrstitve, so zgrajene atrakcije ločene glede na tiste, ki so zgrajene za turistične namene, in tiste, ki tega namena prvotno niso imele. Za slednje Leask (2002) meni, da pogosto zahtevajo višje fiksne stroške obratovanja, imajo omejeno zmogljivost, ki se jo ne da spreminjati, ter predvsem morajo izpolnjevati svoj prvotni namen (npr. cerkve).

Inskeep (199I) loči:

- naravne privlačnosti, te temeljijo na naravnih danostih,

- kulturne privlačnosti, te temeljijo na človekovih aktivnostih, in

- posebne privlačnosti, ki so umetno ustvarjene.

Howie (2003) loči med otipljivimi (fizičnimi) in neotipljivimi privlačnostmi. $\mathrm{V}$ prvo skupino prišteva naravne in kulturne privlačnosti destinacije, $\mathrm{v}$ drugo pa občutke dobrodošlice, varnosti, navdušenja, mladostnosti, dinamike, inspiracije, ki lahko vplivajo na edinstvenost izkušnje potnika.

Kušen (2002) turistične privlačnosti razdeli v tri skupine:

I. naravne privlačnosti (geološke značilnosti, podnebje, voda, rastlinski svet, živalski svet, naravna dediščina),

2. kulturno-zgodovinske privlačnosti (kulturno-zgodovinska dediščina, kulturne in religiozne ustanove, prireditve, znameniti ljudje in dogodki, kultura življenja in dela),

3. privlačna turistična superstruktura (športno-rekreacijski objekti, zdraviliški objekti in ustanove, atrakcije zaradi atrakcij - igralnice). 
Privlačnosti glede na motivacijo turista lahko razdelimo tudi na (Mill in Morrison, 2002, v Vodeb, 2014, str. 38):

I. primarne, ki ustvarjajo osnovno motivacijo obiskovalca - razlog, da se jih obišče in doživi, in

2. sekundarne, ki imajo turistično privlačnost, ta pa ni takšna, da bi nekdo obiskal določeno destinacijo izključno zaradi nje. Običajno so sekundarne atrakcije na poti do primarne atrakcije. V literaturi zasledimo izraz $\gg$ stopover atrakcije $\ll$.

Pri zgoraj navedenih vrstah virov oz. atrakcij različnih avtorjev opazimo veliko podobnih ali celo skupnih elementov. Ta pestrost delitve virov nakazuje, da sta tudi tu prisotna svojevrstna kompleksnost pojmovanja in drugačni zorni koti, iz katerih lahko gledamo na vrste virov. Sploh pa je pestrost možnosti razvrstitve po mnenju Leaskove (2008) posledica izjemnega razvoja novih vrst atrakcij in povečanja povpraševanja v zadnjih 30 letih. Skozi zgodovinski pregled razvoja turističnih privlačnosti smo ugotavljali, da je sprememba $v$ vzorcih preživljanja prostega časa dejavnik, ki vpliva na pojav novih vrst atrakcij, in to potrjujejo tudi drugi avtorji (Leask, 2018).

Sklenemo lahko, da je razvrščanje privlačnosti smiselno zlasti z vidika upravljanja turističnih atrakcij, kar bo tema razprave v naslednjih poglavjih. 


\section{Turistični vplivi in turistične atrakcije}

Ker so sestavni (vitalni) del turizma, so turistične atrakcije deležne vseh turističnih vplivov. Ker pa je prostor vitalni organ atrakcije, predstavljajo turistični vplivi skupek sprememb $\mathrm{v}$ tem prostoru (naravnem in družbenem), ki se kažejo kot posledica turističnih aktivnosti in s tem povezanimi dejanji. Vsaka človeška aktivnost $\mathrm{v}$ prostoru namreč povzroči določeno spremembo, ki pa je zaradi heterogenosti tega prostora večplastna in jo lahko glede na vidik zaznave opišemo drugače.

Turistični vplivi nastanejo predvsem zaradi interakcij, ki so značilne za turizem, to so interakcije med turisti, domačini in turistično destinacijo. Dodatno vplive povzroča dejstvo, da so dobrine v nekem prostoru omejene, povpraševanje po njih pa je večje, kot je na razpolago dobrin, zaradi česar prihaja do neusklajenosti ponudbe in povpraševanja. To so ključni razlogi nastanka turističnih vplivov, zato jih je potrebno zelo resno obravnavati, razumeti ter upravljati. Upravljamo namreč lahko le tisto, kar poznamo in razumemo. Torej, če je poznavanje in razumevanje nekega pojava pogoj za njegovo obvladovanje in upravljanje, je cilj turističnega gospodarstva in drugih akterjev $\mathrm{v}$ turizmu zagotovo učinkovito obvladovanje in upravljanje s turističnimi viri. Turistični viri so torej v tesni povezavi s procesom načrtovanja in upravljanja turističnih atrakcij.

Prostor, tako družbeni kot naravni, je temeljni sestavni del turizma in turistične atrakcije, zato je njegov pomen pri obravnavi turističnih vplivov vedno v ospredju. Prostor atrakcijo določa in zaznamuje, iz njega atrakcija črpa svoje lastne značilnosti in identiteto. To pa je ključnega pomena za njen razvoj in konkurenčne prednosti, ki jih s tem dosega na turističnem trgu. O tem smo izdatno razpravljali v predhodnih poglavjih. 
Turistični vplivi so docela pereča problematika v teoriji in praksi turističnih atrakcij, o čemer se v zadnjih tridesetih letih zelo veliko govori in piše, pa vendar je aplikacija teh znanj in rešitev na proces načrtovanja in upravljanja turističnih atrakcij relativno skromna.

\section{Vrste turističnih vplivov}

Pri razumevanju nekega pojava lahko uporabljamo različne načine pristopov, med drugim tudi to, da ugotavljamo različne vzorce pojava, s čimer lahko poudarimo medsebojne razlike in značilnosti tega pojava. O vrstah turističnih vplivov je govora, ko želimo nakazati, na koga ali na kaj se dejansko nanaša določen turistični vpliv, zato v literaturi najpogosteje omenjajo tri osnovne skupine turističnih vplivov. Ti so ekonomski, družbeni in okoljski.

Ločimo tako pozitivne kot negativne ekonomske vplive. Med prve prištevamo:

- bruto domači proizvod,

- priliv deviz in vpliv na plačilno bilanco,

- razvoj manj razvitih območij,

- zaposlovanje in dvig življenjskega standarda,

- povečan obseg naložb,

- prispevek k regionalnemu razvoju,

- vrednotenje dobrin, ki brez turizma ne bi postale blago (morje, gore, jame, razgled ...), ter drugi.

Negativni ekonomski vplivi pa so:

- dražji življenjski standard za domačine (višje cene življenjskih potrebščin),

- povečanje cen zemljišč in najemnin,

- sezonska brezposelnost,

- slabo plačana dela v gostinstvu in neugodni delovni pogoji,

- uvoz delovne sile in drugi.

Mason (2015, str. 34) za ekonomske turistične vplive meni, da so v primerjavi z drugimi vrstami vplivov najbolje raziskani. Tudi sicer je to najbolj raziskano področje turizma. Te vplive raziskujejo ekonomisti v povezavi s turističnim razvojem, prihodki in z zaposlitvijo. Avtor prav tako opozarja na zelo škodljive ekonomske turistične vplive, ki pa jih vidi $\mathrm{v}$ inflaciji, oportunitetnih stroških in pretirani odvisnosti od turizma. Inflacija, kot posledica razvoja turizma, po njegovem vpliva na dvig cen zemljišč, kar se kaže kot sprememba, izzvana s turističnim razvojem. Prav 
tako oportunitetni stroški predstavljajo posledico turističnega razvoja, kjer se namesto $v$ druge gospodarske aktivnosti vlaga $v$ turizem. Pretirana odvisnost od turizma pa je značilna za države, ki svoj razvoj utemeljujejo pretežno ali izključno na turističnem razvoju in so druge gospodarske aktivnosti podcenjene ter manj razvite. Nevarnost za take države je v vsaki spremembi turističnega povpraševanja, ki lahko povzroči veliko gospodarsko krizo.

Poudarjanje pomena ekonomskih turističnih vplivov je značilno za obdobje množičnega turizma kakor tudi za manj razvite države. Čudi pa prepričanje nekaterih uveljavljenih ekonomistov v Sloveniji (Tajnikar 2000), da je turistični razvoj primeren in ustrezen le za manj razvite in tranzicijske države. To stališče seveda demantirajo podatki o indeksu turistične konkurenčnosti, ki ga pripravlja Svetovni ekonomski forum (ang. World Economic Forum - WEF), ki na podlagi zanesljive metodologije med najrazvitejše turistične države uvršča ravno tiste, ki so konkurenčne tudi v drugih dejavnostih. Zagotovo velja, da lahko hiter in nenačrtovan razvoj turizma povzroči veliko negativnih turističnih vplivov, ekonomskih, družbenih in okoljskih, zato je potrebno govoriti o turističnih vplivih $\mathrm{v}$ povezavi s turističnim načrtovanjem. Obravnava turističnih vplivov pa mora biti nujno celovita, kar pomeni, da je treba vedeti, kakšne so značilnosti turističnih vplivov, o čemer bo govora v naslednjem podpoglavju.

Pozitivni družbeni vplivi turizma so:

- višanje kakovosti življenja lokalnega prebivalstva,

- odpiranje novih delovnih mest,

- ohranjanje in razvoj obrti ter podjetništva,

- trženje lokalnih proizvodov,

- ohranjanje poselitve in kulturne pokrajine,

- oovečanje prepoznavnosti turističnega kraja,

- krepitev kulturne identitete in drugi.

Negativni družbeni vplivi turizma so:

- sprememba življenjskega sloga in obnašanja domačinov,

- opuščanje avtohtone kulture, navad in običajev,

- opuščanje tradicionalnih obrti,

- sprememba videza zgradb in vzorcev poselitve,

- zmanjšanje varnosti (kriminal, prostitucija ...),

- socialna izključenost domačinov in drugi.

Turizem je zaradi pomena družbene interakcije pretežno družbeni pojav, gre namreč za kulturno mobilnost, odnose in vedenja, ki so značil- 
ni v turizmu. Ko govorimo o družbenih vplivih turizma, govorimo o odnosu domačinov do turizma in turistov ter obratno, o odnosu in vedenju turistov, njihovi motivaciji in zadovoljstvu. Sestavni deli vsake družbe so njeni kultura, jezik, sistem vrednot, kulturnih praks, običajev in navad. Kulturne privlačnosti so lahko kulturne prireditve in dogodki, umetnost in glasba, gastronomija, arhitektura, zgodovina ipd. Kultura ima v turizmu čedalje večji pomen in turizem je lahko njen promotor, če je le načrtovan na pravi način. Etnologi in antropologi bi rekli, da je turizem stičišče različnih kultur.

V turizmu nastopajo najmanj lokalna kultura, turistična kultura, uvožena kultura in organizacijska oz. poslovna kultura. Gre za različne vrste kultur, pri čemer sta lokalna in uvožena kultura kulturi etničnih skupin, medtem ko turistična ali poslovna kultura nista kulturi etničnih skupin - ravno nasprotno, ti dve kulturi zlasti v turizmu predstavljata mešanico pripadnikov etničnih skupin. Lokalna je kultura domačinov, odraža njihov način življenja, navade in običaje, vrednostni sistem. Ta kultura je tipična, pristna, lahko pa je eksotična (odvisno od domače kulture turista - njegove lastne kulture), lahko je tudi razlog za kulturni šok (če preveč odstopa od pričakovanj obiskovalcev). Značilno za turistično kulturo je, da ni del nekega geografskega prostora ali časovne (zgodovinske) dimenzije, pač pa nastaja na potovanju med izhodiščem in ciljem. Odraža način življenja in odnose turistov na potovanju, nastaja kot tipičen slog življenja posameznih tipov turistov. Fenomen množičnih turističnih potovanj in institucionalizacija turizma $\mathrm{v}$ mednarodnih razmerah sta ustvarila specifično identiteto turista $\mathrm{v}$ primerjavi z ostalimi potniki. V skrajnih primerih je lahko rušilna sila lokalne skupnosti ali družbe. Tudi turistična kultura je lahko razlog za kulturni šok domačinov, v kolikor preveč odstopa od njihovih pričakovanj. Uvožena kultura je kultura prostora in zgodovine obiskovalcev, turistov, njihovega domicila; je tista, ki jo turisti prinesejo s seboj, kot prtljago iz države, iz katere prihajajo. Gre za nekatere dominantne vrednote in vzorce nacionalne kulture (Američani, Angleži, Nemci, Japonci), vendar se je pri tem treba izogibati stereotipom. Tudi uvožena kultura je lahko za domačine razlog za kulturni šok zaradi prevelikih odstopanj od njihovih pričakovanj. Ne moremo mimo turistične poslovne kulture ali organizacijske kulture, ki nastaja predvsem znotraj multinacionalk (hotelske verige, korporacije ipd.) in izvira iz organizacijske kulture teh podjetij. Ponekod je pomen takih velikih organizacij v turističnem gospodarstvu takšen, da je odtis te vrste kulture v interakciji s turisti in domačini precejšen, saj v stik prihajajo zaposleni, gosti in domačini. Na ta način prihaja do ustvarjanja določenih stereotipov in tudi 
integracij (culture mix). Pri vsem tem je treba vedeti, da je kutura zmeraj bila in je še vedno izjemno dinamična kategorija, kar je v današnjem času posledica globalne socialne mobilnosti.

Stik kultur, kar nenazadnje turizem je, naj bi bil interferenca (prepletanje) ustvarjalnih, vsebinsko bogatih trenutkov za turista in domačina, bogatenje kultur in izkušenj, priložnost za prevetritev lastnega vrednostnega sistema, zavedanje, da drugačnost bogati, priložnost za spoznanje lastne identitete ter spoštovanje sebe in drugih. Stik kultur pa naj ne bi bili površni, pasivni stiki turistov in domačinov, brez iskrene želje spoznati in razumeti drug drugega, naj ne bi bil le farsa, ki je del »predstave« ali spektakla, poveličevanje sebe in zaničevanje drugih, nevoščljivost, sovražnost ali celo konflikt. Najmanj škode povzročamo, ko je stopnja medsebojnega spoštovanja skupin (obiskovalcev in domačinov) na visoki ravni, ko je z obeh strani izkazan interes za spoznavanje novih pogledov na svet, običajev in vrednot, ko je zagotovljena visoka stopnja sprejemljivosti za drugačnost in ko se obe skupini vedeta odgovornosti druga do druge.

Večje razlike med kulturami, ki jim pripadajo obiskovalci oz. gostitelji, lahko sprožajo večje turistične vplive. Doživetja obiskovalcev in gostiteljev so odvisna od njihovih pričakovanj, izkušenj in stopnje zavedanja.

Obstajajo različne metode ugotavljanja in spremljanja družbenih vplivov turizma. Ena od zelo znanih je Doxey Irritation Index ali krajše model Irridex. Ta spremlja spremembe družbenih odnosov med obiskovalci in domačini v času razvoja nekega turističnega kraja. Doxey (1975) namreč razlaga, da gre vsak turistični kraj v svojem razvoju skozi štiri različne faze razvoja družbenih odnosov med turisti in lokalnim prebivalstvom. Te faze imenuje:

I evforija ali navdušenje,

2. apatija ali pasivnost,

3 zasičenost ali vznemirjenje,

4. antagonizem ali nasprotovanje.

Evforija ali navdušenje je prisotno $\mathrm{v}$ začetni fazi razvoja turizma $\mathrm{v}$ kraju, ko je prisotno manjše število obiskovalcev. Lokalno prebivalstvo slednje sprejema $z$ iskrenim navdušenjem in navdušenost je obojestranska. Vladajo neuradna gostoljubnost, pristnost, avtentičnost in domačnost. Število obiskovalcev je obvladljivo, ustvarja se kakovosten odnos, kar obe strani navdaja z navdušenjem.

Apatija ali pasivnost je naslednja faza v razvoju družbenih odnosov med lokalnim prebivalstvom in obiskovalci, ki se pojavi predvsem zara- 
di povečanega števila turistov. Ko število turistov preseže mejo, do katere je možno ohranjati kakovostne odnose med lokalnim prebivalstvom in turisti, se začnejo prve težave. Zaradi obvladovanja večjega števila turistov neuradno in pristno gostoljubnost pri prodaji turističnih proizvodov in storitev zamenjajo uradni odnosi, pojavi se potreba po načrtovanju novih priložnosti, zlasti na področju trženja. Turizem postane posel, ki zahteva posloven odnos, treba ga je načrtovati, organizirati in upravljati. Lokalni prebivalci se v odnosu počutijo in vedejo pasivno, kar se prenaša tudi na obiskovalce.

Zasičenost ali vznemirjenje je faza, ko lokalni prebivalci že čutijo in kritizirajo negativne učinke turizma - predvsem jih motijo gneča, prometne konice, hrup in podobno. Lokalne oblasti pri omejevanju razvoja turizma nimajo podpore zasebnega sektorja (podjetnikov), saj je dobiček od turizma v tej fazi najvišji doslej, investicije v infrastrukturo pa so še vedno donosne.

Antagonizem ali nasprotovanje je faza močnega in odkritega nasprotovanja turističnemu razvoju ter njegovim posledicam pri lokalnih prebivalcih. Za vse negativne učinke turizma lokalni prebivalci krivijo turiste in jih brez zadržkov »obsojajo « za svoj položaj. Počutijo se ujeti v verigo turistične industrije, izrabljeni v kolesju turizma. Jezijo se na turiste, češ, da niti pred lastno hišo nimajo več prostora za parkiranje, da so izrinjeni iz lokalnih parkov, da kopališče ni več takšno, kot je bilo ipd. (Vodeb, 2014, str. 86-88).

Model Irridex je ena od najpopularnejših metod merjenja sprememb družbenih odnosov med obiskovalci in domačini v turizmu nekega kraja, a kljub temu velikokrat kritizirana, češ da si faze ne sledijo nujno v takem zaporedju in v tolikšni meri (Mason, 2015), kar je dokaz, da je treba vsak primer turističnega kraja obravnavati ločeno in upoštevaje okoliščine in značilnosti turističnega razvoja.

Med pozitivne okoljske vplive turizma uvrščamo:

- zaščito naravnega in kulturnega okolja z vključevanjem v turistično ponudbo,

- turizem kot vir finančnih sredstev za zaščito naravnega okolja,

- turizem kot razlog za izboljšanje naravnega okolja,

- oblikovanje in krepitev ekološke zavesti, ekološke etike in ekološke odgovornosti zaradi turizma in druge.

Kot negativne okoljske vplive turizma razumemo:

- uničevanje in onesnaževanje narave,

- razvrednotenje naravnih dobrin, 
- onesnaževanje in povečana poraba vode,

- onesnaževanje zraka in drugih pokrajinskih elementov zaradi prometa,

- spremembe reliefa, povečanje erozijskih procesov (gradbeni posegi, umetna smučišča, motokros, gorsko kolesarjenje, ipd.),

- krčenje ali uničenje avtohtonih živalskih in rastlinskih vrst (hrup, lov, ribolov, nabiranje rastlin, odlaganje odpadkov ipd.) in druge.

Glede na velik pomen prostora v turizmu v smislu naravnega ali fizičnega okolja so tudi okoljski vplivi turizma neizogibni. Največja ironija okoljskih vplivov turizma je ta, da je narava, kot (pogosto) primarna turistična atrakcija, prizadeta in poškodovana zaradi okoljskih vplivov turizma. Množični turizem oz. njegove negativne vplive si najprej predstavljamo predvsem kot negativne okoljske vplive. Swarbrooke (1999, v Mason, 2015) poda podrobnejši in celovitejši vpogled v okolje. Slednjega deli na pet vzajemno povezanih in soodvisnih enot:

I. naravno okolje (gore, morja, reke, jezera),

2. divjino (flora, favna),

3. gojeno okolje (kmetijske površine, ribogojnice),

4. grajeno okolje (posamezne stavbe, vasi, transportna infrastruktura) in

5. naravne vire (voda, klima, zrak).

Okolje, v vseh zgoraj omenjenih oblikah, lahko zelo različno reagira na turistične vplive, v odvisnosti od tega, za kakšno turistično atrakcijo gre, kakšne turistične aktivnosti so s tem povezane, kakšna je turistična infrastruktura in za kakšno okolje gre. Nekatera okolja so bolj, druga manj občutljiva in dovzetna za turistične vplive. Kjer je prisotna neenakomerna koncentracija delovanja atrakcije in s tem neenakomerna koncentracija obiskovalcev, je pričakovati več negativnih posledic na okolje zaradi sezonskih pritiskov. Urbana okolja se na okoljske vplive odzivajo drugače od ruralnih. Predvsem je treba poudariti, da učinkovito načrtovanje in organizacija turističnih atrakcij ter njene infrastrukture vpliva na to, da so negativni učinki na okolje manjši.

Obstajajo različne metode spremljanja okoljskih vplivov v turizmu in ena najbolj znanih $\mathrm{v}$ literaturi, zadnje čase pa tudi v praksi, je nosilna zmogljivost (ang. carrying capacity).

Nosilna zmogljivost turistične destinacije je maksimalno število ljudi, ki lahko uporabljajo nek kraj, ne da bi pri tem prišlo do nesprejemljivih sprememb v fizični okolici in do nesprejemljivega padca kakovosti tu- 
rističnega doživetja (Mathieson in Wall, 1996). Meja nosilne zmogljivosti ni enostavno opredeliti, nujno pa jih je nadzirati in slediti spremembam.

$\mathrm{Za}$ načrtno uveljavljanje trajnostnega razvoja turizma je ključnega pomena pravočasno in celovito prostorsko načrtovanje, ki v strategijah načrtovane posege umešča $v$ prostor. Svetovna turistična organizacija (UNWTO) in Program Združenih narodov za okolje (UNEP) poleg celovitega prostorskega načrtovanja regij in usklajenega upravljanja turističnih destinacij priporočata analizo nosilne zmogljivosti posameznih destinacij in turističnih krajev. $\mathrm{Z}$ analizo nosilne zmogljivosti za turizem se opredeli maksimalno število obiskovalcev, ki lahko hkrati obiščejo regijo ali turistično destinacijo, ne da bi pri tem povzročili nesprejemljive posledice za prostor ter ekološko, družbeno in gospodarsko okolje. Metoda analize nosilne zmogljivosti se je $\mathrm{v}$ mednarodni praksi izkazala kot ustrezen pripomoček za preprečevanje prenasičenosti turistične destinacije in za uresničevanje načel trajnostnega turizma $\mathrm{v}$ praksi. Zelo pomemben je tudi učinek, ki ga ima sam proces analiziranja nosilne zmogljivosti na lokalno prebivalstvo, turistično gospodarstvo in lokalno upravo. $\mathrm{Z}$ njihovim aktivnim vključevanjem ima ta proces hkrati tudi funkcijo izobraževanja in ozaveščanja o nujnosti trajnostnega razvoja turizma (Jurinčič, 2005).

Nosilna zmogljivost je večplastna, saj se nanaša na družbeno, naravno in gospodarsko okolje; zaradi tega je spremljanje teh parametrov dokaj kompleksno.

V literaturi so največkrat omenjeni sledeči štirje pragi, ki jih turistični kraj zaradi trajnostne naravnanosti ne sme prestopiti:

I. ekološki prag (toleranca ekosistema),

2. prag infrastrukturnih zmogljivosti (število nastanitvenih in gostinskih zmogljivosti),

3. prag tolerance lokalnega prebivalstva (zaznava gneče, hrupa),

4. prag tolerance turistov (zasičenost, banalnost, degradacija prostora).

Toleranca ekosistema je odvisna od vrste in lastnosti nekega ekosistema, občutljivost slednjih je tudi zaradi tega lahko različna. Tako ekosistem $\mathrm{v}$ ruralnem okolju $\mathrm{s}$ kakovostno podtalnico, ki predstavlja pomembno vodno zajetje za neko regijo, ni enako občutljiv kot ekosistem v nekem urbanem okolju, ki služi predvsem kot manjša parkovna površina. Prag infrastrukturne zmogljivosti je določen s prostorom in prostorskimi omejitvami in je lažje določljiv, saj obstajajo standardi urbanistike in prostorskega načrtovanja, primernega za različna okolja (npr. spalno naselje, 
industrijska cona). Prag tolerance domačinov in turistov pa sta težje določljivi kategoriji, ker temeljita predvsem na subjektivnih zaznavah, odnosu do le-teh in posledičnih reakcijah posameznikov. Domačinom v že turistično razvitem kraju je včasih lažje sprejeti gnečo in hrup zaradi turizma, ker so nanj navajeni in ker te pomanjkljivosti vzamejo $\mathrm{v}$ zakup in $\mathrm{v}$ zameno za koristi od turizma, ki jih prepoznajo.

Nosilno zmogljivost destinacije lahko delimo na osnovi treh vidikov:

- z vidika virov je lahko t. i. fizična nosilna zmogljivost (število ležišč, parkirnih mest, letalskih sedežev - preprosto merljiva) in biološka nosilna zmogljivost (določa meje razpoložljivosti ekosistema - težko merljiva);

- z vidika turistov je lahko t. i. psihološka ali zaznavna nosilna $z m o g l j i v o s t$, ki se nanaša na trenutek, ko turisti občutijo, da bi bilo nadaljnje povečanje števila turistov zanje moteče (zelo težko merljivo, ker je del subjektivnih občutkov posameznikov);

- $\quad$ z vidika lokalne skupnosti je lahko t. i. socialna nosilna zmogljivost (sposobnost tolerance lokalnih prebivalcev do turistov, ki pomaga pri načrtovanju destinacije).

Združenje narodnih parkov ZDA je razvilo matematično formulo za izračun nosilne zmogljivosti turistične destinacije, ki velja predvsem za zaščitena ali zavarovana območja, kot so narodni, krajinski parki in podobno:

$$
\mathrm{CC}=\mathrm{f}(\mathrm{Q}, \mathrm{T}, \mathrm{N}, \mathrm{U}, \mathrm{DM}, \mathrm{AB}),
$$

pri čemer:

CC - carrying capacity (nosilna zmogljivost destinacije), Q - fizična velikost destinacije, $T$ - toleranca izkoriščanja virov turistične ponudbe, $\mathrm{N}$ - število turistov, $\mathrm{U}$ - vrsta izkoriščanja virov turistične ponudbe, $\mathrm{DM}$ - menedžment turistične ponudbe, $\mathrm{AB}$ - navade in odnos lokalnega prebivalstva ter menedžerjev.

Nosilna zmogljivost destinacije ni zgolj znanstveni koncept, ki določa maksimalno število turistov, ki ga lahko sprejme destinacija, ne da bi s tem povzročali zmanjšanje kakovosti turistične ponudbe, pač pa gre za proces, $v$ katerem morajo biti določene omejitve vzete kot svojevrstna usmeritev razvoja destinacije $\mathrm{v}$ prihodnje. Nosilna zmogljivost destinacije tako ni trdno določena in se $s$ časom spreminja, odvisna pa je predvsem od (Vodeb, 2014, str. 89-90):

- sezone, 
- vedenjskih navad turistov,

- destinacijskega menedžmenta,

- dinamičnih okoljskih sprememb,

- sprememb v odnosu lokalnega prebivalstva.

Če na nosilno zmogljivost destinacije gledamo kot na proces, dobimo učinkovito orodje za načrtovanje in usmerjanje razvoja destinacije v skladu s spremembami v okolju. Razvoj destinacije je treba nujno načrtovati in usmerjati, da $\mathrm{v}$ ekonomskem, družbenem in prostorskem smislu dosežemo optimalne rezultate (Vodeb, 20I4).

Razvrstitev turističnih vplivov na gospodarske, družbene in okoljske je zgolj informativna in zelo splošna, kar lahko vpliva na njihovo razumevanje in sposobnost učinkovitega upravljanja. V literaturi obstaja še vrsta drugih podobnih (poskusov) razvrstitev, ki pa so si med seboj zelo podobne, toda to ne prispeva $\mathrm{k}$ njihovemu razumevanju $\mathrm{v}$ procesu načrtovanja in upravljanja, če ne poznamo značilnosti turističnih vplivov.

\section{Značilnosti turističnih vplivov}

Obstajajo določena dejstva o turističnih vplivih, ki predstavljajo osnovo za njihovo razumevanje, kar je predpogoj za uspešno upravljanje le-teh. Ta dejstva lahko označimo za značilnosti turističnih vplivov, katerih poznavanje in razumevanje $\mathrm{v}$ veliki meri opredeljuje možnosti za njihovo upravljanje.

Prvo tako dejstvo ali značilnost o turističnih vplivih je to, da vedno obstajajo. Še v zadnjem četrtletju preteklega stoletja je veljalo prepričanje (ponekod, žal, to velja še danes), da turistični razvoj nima negativnih posledic. Prepogosto namreč v sodobni turistični praksi slišimo, da je možno dosegati le pozitivne turistične vplive. To seveda ne drži, kljub vsem naporom in učinkovitosti delovanja turističnega sistema. To je teoretično in praktično nemogoče.

Naslednja značilnost turističnih vplivov je ta, da so vedno pozitivni in negativni. Glede na to, da se jim ne moremo izogniti, kajti vsaka turistična aktivnost sproža nekakšne turistične učinke, je treba vedeti, da so ti vedno pozitivni in negativni. Razlike so zgolj v razmerju med njimi. Tisto, na kar lahko vplivamo z načrtovanjem in upravljanjem turističnih vplivov, je ravno to razmerje. Toda da bi kakorkoli lahko vplivali nanje, moramo razumeti njihovo vsebino, značilnosti in delovanje.

Poleg dejstva, da vplivi vedno obstajajo, da so vedno pozitivni in negativni, je treba vedeti tudi to, da so medsebojno povezani in učinkujejo eni na druge. To dejstvo govori o tem, da je turistične vplive potrebno 
spremljati in razumeti znotraj njihovega konkretnega okolja in konteksta. Ni univerzalnih turističnih vplivov, ki jih lahko po enotni formuli pričakujemo na podlagi turističnih aktivnosti, ki jih sprožajo turistične atrakcije. Ti so vedno odvisni od konkretnih razmer, značilnosti okolja in vsebine atrakcije. Določena turistična atrakcija oz. turistične aktivnosti, ki izhajajo iz njenega delovanja, lahko sprožajo vrsto pozitivnih vplivov za določeno skupino akterjev v turizmu (npr., turistično gospodarstvo ima lahko pozitivne gospodarske učinke skozi zaposlitveno funkcijo turizma), medtem ko ta ista atrakcija za druge akterje v turizmu lahko sproža negativne vplive (npr., lokalna skupnost trpi zaradi hrupa in svetlobnega onesnaževanja, ki ga sproža delovanje turistične atrakcije).

Naslednja značilnost turističnih vplivov je njihova minljivost in spremenljivost $\mathrm{v}$ času. Vrste turističnih vplivov menda določajo vrsta turističnih atrakcij in aktivnosti, lastnosti lokalne skupnosti in vrsta interakcije med obiskovalci in gostitelji (Mason, 2015). Nedvomno pa so turistični vplivi odvisni tudi od sodelovanja in interakcije vseh akterjev v sistemu turistične atrakcije, denimo, kakovosti mrežnih partnerstev in njihovih učinkov.

Mason (2015) izpostavlja, da ima lahko turizem kot vrsta družbene aktivnosti velik vpliv na naravno in družbeno okolje. Do vplivov tako prihaja zaradi interakcije obiskovalcev z lokalnim okoljem, kulturo in domačini. Še pomembnejše pa je dejstvo, da splošna delitev turističnih vplivov na tri kategorije (gospodarski, družbeni in okoljski) pravzaprav ni ustrezna, kajti turistični vplivi so večplastni in takšna preprosta delitev resno zmanjšuje možnost njihovega učinkovitega načrtovanja in upravljanja. Denimo, noben gospodarski vpliv ni izključno gospodarski. Tukaj pride do izraza prepletenost in medsebojno učinkovanje turističnih vplivov, kar pa je pomemben dejavnik pri njihovem upravljanju. Prepletenost turističnih vplivov je tudi posledica interakcij deležnikov v turizmu.

Ne glede na vrsto ali predznak turističnega vpliva je njegovo dojemanje pogojeno s tistim, na kogar se nanaša. Njihovo ločeno obravnavo lahko pogojno podpremo le s teoretičnega vidika, $v$ praksi pa je zagotovo potrebno celovito razumevanje turističnih vplivov v širšem kontekstu, upoštevaje njihovo večplastno naravo oz. značilnosti. Predznak in intenziteta turističnega vpliva lahko variirata glede na interese, vlogo in relacije posameznika v zvezi s turistično atrakcijo. Mason (2015) poudarja tudi dejstvo, ki ga potrjujejo številne nedavne študije s tega področja, da je zaradi koristi od turizma (npr. delovna mesta, višji zaslužek, višja kakovost življenja ipd.) lokalna skupnost pripravljena sprejeti nekatere njegove negativne vplive (npr. hrup, gneča, povečanje cen zemljišč). 


\section{Razumevanje, načrtovanje in upravljanje turističnih vplivov}

$\mathrm{V}$ sodobnem turizmu gre za doživetja in izkušnje, ki nastajajo med atrakcijo, gostitelji in obiskovalci. Pri tem gre za družbeni, okoljski in gospodarski fenomen, ki temelji na interakciji, kjer pa so interakcija tudi procesi. Torej, da bi razumeli turistične vplive atrakcij, moramo razumeti interakcije znotraj sistema atrakcije in procese, ki potekajo znotraj njega. Vsak proces $v$ sistemu nedvomno sproža raznotere učinke oz. povratne informacije, ki pa so, če jih s pridom uporabljamo, izjemno dragocen vir informacij in orodje za načrtovanje ter razvoj turistične atrakcije.

Archer, Cooper in Ruhanen (2005, str. 79) opažajo, »da turistične aktivnosti sprožajo učinke, ki se jim ne moremo izogniti, lahko pa jih načrtujemo tako, da povečujemo pozitivne in zmanjšujemo negativne učinke«. To je v domeni menedžmenta turistične atrakcije. Ti učinki so posledica interakcije med velikim številom obiskovalcev in domačinov, ki pa imajo različna družbeno-kulturna ozadja. Vendar, bolj kot same učinke, ki so posledica procesov, nastalih v interakciji, je potrebno razumeti razloge in vzroke za določene pojave. Sami učinki so namreč zelo statična in pasivna kategorija informacij za upravljanje. Ko se z njimi seznanimo, je največkrat že prepozno in so izidi oz. posledice določenih učinkov (zlasti negativnih) že prisotni. Vsekakor za menedžment turistične atrakcije ni dovolj biti seznanjen z vplivi turizma, pač pa sta potrebna znanje in sposobnost za uporabo informacij o njihovih učinkih, da lahko pridemo do vzrokov in pomenov. Šele takrat postanejo za menedžment koristno orodje v procesu odločanja ter nadaljnjega načrtovanja turistične atrakcije.

Na tem mestu je potrebno spregovoriti o stopnjah menedžmentove obravnave turističnih vplivov, saj pri tem vidimo logično povezavo s tremi vidiki turističnega sistema, kot jih opisuje Laws (1995). Kot zagovornik sistemske teorije turizem razume kot povezavo posameznih enot, ki delujejo na podlagi medsebojne interakcije. Spričo interakcije in procesov, ki v sistemu delujejo, vanj vstopajo nekakšne vhodne enote (ang. inputs) (npr.: upravljavske in tehnične veščine, investicijski viri, pričakovanja turistov), ki se v procesu delovanja sistema spreminjajo v nekakšne izhodne enote (ang. outputs) (npr.: uspeh na turističnem trgu, zadovoljstvo turistov). Skladno s tem za sistem velja, da (Laws, 1995.):

I. so učinki pri outputih posledica sprememb pri inputih (takemu načinu »uporabe« informacij in razumevanju le-teh bi glede na menedžmentovo obravnavo turističnih virov lahko rekli faza seznanjanja), 
2. so deli sistema povezani medsebojno in s svojim okoljem (to fazo menedžmentove obravnave turističnih virov imenujemo faza razumevanja) in

3. kontrola podsistema in procesov temelji na povratnih informacijah (to fazo menedžmentove obravnave turističnih virov imenujemo faza upravljanja).

Sedaj, ko smo poskusili povezati vidike turističnega sistema, kot jih vidi Laws (1995), z različnimi pristopi pri uporabi povratnih informacij $\mathrm{v}$ procesu načrtovanja, smo te imenovali faze menedžmentove obravnave turističnih vplivov. Na podlagi povezovanja vidikov sistema in načina obravnave turističnih vplivov lahko sklepamo, da gre za različne stopnje organiziranosti znotraj turističnega sistema.

V prvi fazi seznanjanja menedžment zgolj zaznava oz. prepoznava, opazuje in ugotavlja turistične vplive. Temu rečemo pasivna faza, ker je reakcijski čas zamujen ali post festum. To je drža menedžmenta, ki nemočno opazuje posledice turistične aktivnosti in turističnega razvoja. Menedžment v tej fazi deluje zgolj kognitivno, saj le opaža dogodke oz. njihove učinke, na žalost pa nanje ne reagira ali pa je reakcija prepozna. $V$ primeru takega ravnanja se turistični vplivi venomer ponavljajo, saj se dejanja in procesi v delovanju turističnega sistema ne spremenijo. Ko menedžment začne povezovati dejstva in informacije o vplivih, ko začne razumevati interakcijo znotraj sistema, je to prvi korak k razumevanju in aktivnejši drži, kar je premik naprej v smeri razumevanja turističnih vplivov. Naslednja faza v obravnavi vplivov je razumevanje, ko se menedžment na nek način poglobi v vplive in začenja razumevati, da percepcije (npr. domačinov o turizmu) niso vplivi in da je treba raziskati njihov odnos do vplivov, da bi jih razumeli. Z odkrivanjem povezanosti dogodkov in vplivov menedžment začenja razumevati, zakaj in kako se nekaj dogaja, ne pa zgolj, kaj se dogaja. Razumevanje interakcije v sistemu daje menedžmentu globlji vpogled v stanje, kar je lahko učinkovito orodje pri upravljanju. Tej fazi pravimo aktivna faza, saj je reakcijski čas bistveno krajši kot v prvi, kjer zgolj nemočno opazujemo, kaj se dogaja. Iz te faze se menedžment lahko veliko nauči in dojame, da ima moč upravljanja vplivov na način, da jih opazuje, spremlja, predvideva, načrtuje in usmerja. Razume, da je njegova vloga veliko več kot opazovalna, pasivna in statična ter da lahko na vplive učinkuje dejanje ali skupek dejanj, zato dojame, da je treba reagirati proaktivno. Delovanje na ta način mu omogoča optimalne rezultate in učinkovitost, uspeh in kakovostne rezultate v določenih okoliščinah. Prav tako lahko tak način delovanja in obravnave vplivov turizma privede do konkurenčnih prednosti na turističnem trgu. $Z$ vidika menedžmen- 
ta turističnih atrakcij torej poznamo tri zgoraj opredeljene faze obravnave turističnih vplivov:

I. seznanjanje (pasivna drža),

2. razumevanje (aktivna drža),

3. upravljanje (proaktivna drža).

Nemogoče je razvijati turizem brez vpliva na okolje, vendar je treba $s$ pravilnim načrtovanjem upravljati turistični razvoj tako, da se negativni učinki minimizirajo in pozitivni učinki maksimirajo. To je trajnostni koncept razvoja turizma. Upravljanje vplivov turizma je orodje uspešnega načrtovanja atrakcije. Dolgoročni razvoj turizma je odvisen od sposobnosti menedžmenta za valorizacijo turističnih virov. Pri tem je ključnega pomena optimiranje vplivov turizma v skladu s turističnimi viri, znanjem in cilji razvoja. Vselej gre za kombinacijo vplivov, ki pa lahko spodbujajo ali zavirajo razvoj lokalne skupnosti. Jasna ciljna usmeritev in proaktivno načrtovanje združuje različne interese. Proaktivno načrtovanje povezuje cilje turističnega razvoja s splošnimi razvojnimi cilji lokalne skupnosti in združuje različne interese na tem področju. Določena skupina akterjev je lahko deležna pozitivnih ekonomskih vplivov turizma, ti pa hkrati sprožajo manj ugodne družbene in kulturne vplive pri drugih skupinah, medtem ko lahko tretja skupina akterjev trpi negativne okoljske vplive. Podatke o vplivih je treba »dekodirati« v uporabne informacije pri odločitvah in načrtovanju turizma. Omogočiti je treba zanesljivo orodje za napovedovanje in načrtovanje prihodnjih dogodkov. Sodelovanje med akterji je zato ključnega pomena.

Pizam, Uriely in Reichel (2000) dokazujejo, da odnosi med domačini in obiskovalci bistveno vplivajo na zadovoljstvo obiskovalcev s turistično atrakcijo. Enako velja za turistično destinacijo. Zaradi tega je nujno ukvarjati se s tem odnosom, ga celovito spremljati in razvijati v želeni smeri. To lahko zagotovimo le s skrbnim načrtovanjem, ki vključuje vse deležnike v sistemu turistične atrakcije, zlasti lokalno skupnost. Coccossis and Constantoglou (2008) verjameta, da so turistični vplivi ključni parameter $\mathrm{v}$ procesu odločanja in načrtovanja atrakcije, ta proces pa je temelj zagotavljanja njenega trajnostnega razvoja. Zaznavanje turističnih vplivov na ravni lokalne skupnosti je večje tam, kjer je dosežena višja stopnja razvoja turizma. O tem pričajo rezultati raziskav A. Diedrich in E. Garcia-Buades (2009). Tudi drugi avtorji (Nunkoo, Ramkissoon, Gursoy in Chi, 2009) opažajo, da se zaznavanje turističnih vplivov razlikuje med bolj ali manj razvitimi atrakcijami oz. destinacijami. Dvomijo celo $\mathrm{v}$ to, da je $\mathrm{v}$ različno razvitih okoljih možno uporabljati enake modele in 
tehnike spremljanja vplivov. Najpogostejši spremenljivki, ki ju merijo v nedavnih študijah, sta vpliv turizma na kakovost življenja prebivalcev in njihova podpora nadaljnjemu turističnemu razvoju (Deery, Jago in Fredline, 20I2). Pri tem ugotavljajo, da je podpora domačinov pogojena tudi $\mathrm{z}$ njihovo vključenostjo in upoštevanjem $\mathrm{v}$ procesu načrtovanja in razvoja turizma.

Merjenje vplivov turizma $\mathrm{z}$ uporabo zgolj kvantitativnih pristopov pogosto ne daje ustreznih informacij, saj se zaznajo le simptomi, ni pa globljega razumevanja razlogov in vzrokov za nastalo situacijo. Zato raziskovalci za ugotavljanje in spremljanje vplivov turizma priporočajo kombinacijo kvantitativnih in kvalitativnih metod, kar lahko odstre nekatera pomembna vprašanja, ne pa zgolj kaže na simptome, ki jih lahko nato menedžment, v najboljšem primeru, le površinsko sanira.

Trajnostni razvoj turizma je dolgoročen proces in ne enkratni dosežek menedžmenta, ki stremi k uravnavanju interesov številnih deležnikov na destinaciji. Jasno je, da se njihovi interesi precej razlikujejo in da je lahko njihovo sodelovanje v procesu odločanja različno zastopano, pomembno pa je, da menedžment zazna in razume njihove interese.

Področje turističnih vplivov je eno od najbolj obravnavanih v akademske sferi in praksi, pa vendar je še veliko priložnosti za napredek glede iskanja načinov in poti do učinkovitega sodelovalnega ozračja ter metod za vzpostavljanje pogojev za konstruktivni dialog med načrtovalci in vsemi drugimi deležniki. Poleg samih turističnih vplivov je nujno potrebno razumeti vrednote, občutke, navade in odnose, na podlagi katerih se turistični vplivi oblikujejo, ter kako in zakaj jih posamezni deležniki zaznavajo. $V$ veliko korist bi bilo poiskati načine, kako predstaviti koristi razvoja turizma skozi marketinške in menedžerske tehnike, da bi zagotovili sodelovanje akterjev. Prav tako bi bila koristna oblikovanje merljivih ciljev za vse turistične aktivnosti in ustvarjanje pogojev za sodelovalno načrtovanje.

Glede na to, da so turistični viri (družbeni, gospodarski in okoljski) izjemno kompleksni in medsebojno povezani, je treba izpostaviti tudi heterogenost $\mathrm{v}$ zaznavanju teh vplivov pri različnih deležnikih. Tudi znotraj iste skupine deležnikov študije kažejo na razlike v zaznavah. $\mathrm{O}$ tem poročajo številni raziskovalci te problematike (npr. Brunt in Courtney, 1999; Perez in Nadal, 2005; Wang, Pfister in Morais, 2006). Zato razumevanje in vpetost vseh akterjev pripomore $k$ učinkovitejšem odzivu. Seveda je govora o proaktivnem odzivu, ki za razliko od navadnega (aktivnega) omogoča vnaprejšnjo reakcijo subjekta na podlagi predvidevanja in preteklih izkušenj. Proaktivni pristop pomeni predvidevanje dogodkov 
na podlagi informacij in zaznanih pogojev v okolju, kar lahko omogoča preventivno delovanje. Torej bi bilo mogoče razvoj atrakcije usmerjati in načrtovati v želeni smeri in na ta način upravljati tudi vplive turizma. Pri slednjih gre za uglaševanje z želenimi razvojnimi cilji turizma destinacije.

Ko obravnavamo vplive turizma, je treba vedeti, da vpliv turizma ni enako zaznavi tega istega vpliva. Zaznave so načini, kako določene skupine deležnikov v nekem sistemu percipirajo nek vpliv. $S$ tem pa šele vstopamo v globino posameznega vpliva in luščimo ovoje odnosa ter vedenja tistih, ki jih o zaznavah povprašujemo. Gre namreč za zelo subjektivno področje, pa vendar so nekateri dejavniki (spol, starost, izobrazba ipd.) odločilni in jih (zaznave) je na podlagi tega moč tudi sortirati oz. posploševati. Kakorkoli, merjenje turističnih vplivov je vedno težavno, kljub izbiri interdisciplinarnih pristopov, saj so odnosi, ki izhajajo iz interakcije v sistemu atrakcij, najmanj raziskano področje v družboslovnih vedah. Trajnostni turizem tako ni stanje harmonije, pač pa proces, ki temelji na usklajevanju interesov in ciljev vseh deležnikov (Vodeb, 20I4).

Zaznane učinke je treba sporočati različnim akterjem (lokalna skupnost, zasebni neturistični sektor, kulturne institucije) s ciljem spodbujanja dialoga in sodelovanja pri nadaljnjem načrtovanju turizma. Potrebna sta oblikovanje in realizacija sodelovalno-razvojnih ukrepov za učinkovit proces načrtovanja turizma. Pri tem je cilj zmanjšanje negativnih in povečanje pozitivnih vplivov turizma. Vključevanje akterjev v proces odločanja pri načrtovanju turizma je, po prepričanju mnogih, krepitev družbenega kapitala, ki tvorno prispeva $h$ gostoljubnosti, $k$ privlačnosti in $h$ konkurenčnosti same turistične destinacije. Kot je bilo že omenjeno, se vključenost in zadovoljstvo deležnikov v turizmu odraža v kakovosti turističnega doživetja in zadovoljstvu obiskovalca s turistično atrakcijo (Vodeb, 20I4).

V nadaljevanju navajamo nekatere tehnike vključevanja akterjev v turizmu (Chase, Amsden in Phillips, 20I 2):

- diseminacija informacij,

- javna srečanja,

- pridobivanje komentarjev,

- vprašalniki,

- usposabljanje in tehnična pomoč,

- fokusne skupine,

- delavnice,

- delovne skupine,

- proces načrtovanja v velikih skupinah. 
Različne tehnike zahtevajo različno mero angažiranja menedžmenta, saj je pri zgoraj omenjenih tehnikah način komunikacije in vpetosti akterjev lahko zelo različen. Pri diseminaciji informacij, denimo, ne gre za tolikšen angažma in obojestranski prispevek deležnikov kot pri delovnih skupinah. Zato pa ne čudi dejstvo, da je na poti uresničevanja posameznih zgoraj navedenih tehnik veliko ovir.

Izzivi pri vključevanju akterjev so (Chase idr., 20I2):

- nerazumevanje med skupinami akterjev,

- zagotavljanje pravičnosti in enakopravnosti,

- nerazumevanje med institucijami,

- pomanjkanje denarja in časa,

- kompleksnost pri merjenju učinkov.

Zaradi heterogenosti interesov različnih skupin se lahko pojavlja nerazumevanje, boj za »prevlado« enega interesa pred drugimi in podobno. Velikokrat, če ne največkrat, sta problem denar in čas, ki ju je treba nameniti za usklajevanje.

Izhodišča za tehnike vključevanja akterjev $\mathrm{v}$ turizmu temeljijo na konceptu t. i. sodelovanja skupnosti (SP); gre za skupnostni prispevek (ang. community participation), ki se je pojavil sredi 20. stoletja na različnih področjih (urbanizem, zdravstvo in podobno), kjer je pri načrtovanju aktivnosti zahtevano sodelovanje med različnimi akterji. Gre za participativni pristop, ki sodelujočim daje možnost za soodločanje pa tudi soodgovornost za posledice skupnih odločitev. $S$ sodelovanjem pri pomembnih odločitvah o nadaljnjem razvoju sodelujoči prevzemajo odgovornost za svoje življenje, ni vsiljenih posegov $s$ strani tretjih oseb, pač pa je vse stvar dogovora in kompromisov glede na cilje in interese različnih skupin akterjev. Koncept SP tako omogoča (Shani in Pizam, 20I2):

- pravičnejšo distribucijo moči med akterji,

- pravičnejšo delitev koristi in stroškov,

- podporo trajnostnemu razvoju,

- sodelovanje in podporo akterjev,

- možnost uporabe znanja in sposobnosti akterjev,

- inovativne ideje in rešitve,

- učinkovitost, kreativnost in trajnostni koncept razvoja.

Tudi koncept SP ima, podobno kot tehnike vključevanja akterjev v turizmu, svoje notranje ovire, ki pa spet izhajajo iz heterogenosti in različnih ciljev skupin sodelujočih. To so (Shani in Pizam, 20I2):

- pokroviteljski odnos načrtovalcev, 
- nepripravljenost za sodelovanje,

- počasen odziv in neučinkovitost,

- skrivnostnost in neodkritost akterjev,

- postavljanje lastnih interesov v ospredje,

- odtujenost akterjev,

- ignoranca akterjev,

- cenovno in časovno zahtevni projekti,

- konflikti med akterji,

- premoč posameznih skupin,

- nezainteresiranost za sodelovanje,

- slabe pretekle izkušnje s sodelovanjem.

V evropskem prostoru in tudi v Sloveniji je prisotnih kar nekaj od zgoraj naštetih ovir, kar predstavlja oviro v medsebojnem delovanju, tako da je za ustvarjanje zaupanja in spodbujanje dialoga potrebna dolga pot. Najpomembnejši dejavnik za preseganje teh ovir so vendarle pozitivne izkušnje in zaznavanje dodane vrednosti v skupnem delovanju za skupne cilje (Vodeb, 2014, str. 102-107). 


\section{Upravljanje in organizacija turističnih atrakcij}

Uspešna turistična atrakcija nikoli ne obstaja sama po sebi, njeno uspešno delovanje in uspeh so posledica sposobnosti menedžmenta, da dolgoročno (na trajnostni način) načrtuje, organizira in upravlja turistično atrakcijo. Načrtovanje je temeljna funkcija menedžmenta, pri kateri je cilj (Williams, 1998, v Mason, 2015) poiskati optimalne rešitve v dani situaciji, ki bodo prinesle maksimalne koristi in predvidljive rezultate. Gre za urejeno zaporedje aktivnosti, ki so ciljno usmerjene $\mathrm{v}$ reševanje določene problematike. Načrtovanje je tako proces predvidevanja in usmerjanja sprememb, ki temelji na vnaprejšnjem delovanju.

Začetek afirmacije turizma kot pojava in gospodarske dejavnosti je povezan s prepričanjem, da turizem ne more škoditi okolju in da prinaša izključno razvojne priložnosti z nešteto ekonomskimi koristmi, od novih delovnih mest in razvoja regije do podjetniških priložnosti za posameznike. O tem je bilo govora v predhodnem poglavju. Toda to prepričanje, skupaj z razmišljanjem, da so turistični viri neskončno uporabljivi in prosto dostopni, je pripeljalo do množičnega turizma ter njegovih negativnih posledic. To je obdobje $\mathrm{v}$ družbi $\mathrm{s}$ točno določenim vrednostnim sistemom, vedenjskimi vzorci in družbeno strukturo, kjer kolektivno navdušenje do turizma pravzaprav pomeni odnos družbe do turizma kot nekakšne postranske stvari, okrog katere ni prav dosti filozofije ali resnega posla. Zato je $\mathrm{v}$ tem duhu in $\mathrm{s}$ to mentaliteto razvoj turizma lahko samoumeven in »neskončen « tam, kjer se razpolaga z bogatimi turističnimi viri (prijetno podnebje, morska obala ipd.). To je seveda del miselnosti tistega časa, $v$ katerem je na prvem mestu količina in ne kakovost. Integrirano načrtovanje $\mathrm{v}$ turizmu se $\mathrm{v}$ svetu pojavi sredi 6o-ih let prejšnjega 
stoletja, ko se posamezniki v družbi začnejo zavedati prednosti načrtnega delovanja. Sociološke raziskave in razprave $\mathrm{k}$ temu pripomorejo na način, da utopijo o turizmu »raztrgajo « sredi 70-ih in 80-ih let, ko avtorji konfliktnih teorij, kot so Boorstin (1964), Turner in Ash (1975), opozarjajo na »turistične horde « (asociacija na množični turizem) in sociološke deviacije kot rezultat nenačrtovanega razvoja turizma. Konfliktne teorije uničujejo $\gg$ mit $\ll$ o turizmu kot univerzalnemu nosilcu miru in sodelovanja med narodi ter širitvi pozitivnih vrednot. Opozarjajo na kulturne paradokse, izzvane s prihodom turistov in turističnim razvojem, nasprotje vrednot, rušenje socialnega ravnovesja ipd. Prvič se začnemo spraševati o kulturni komercializaciji, promociji lažne avtentičnosti, proizvodnji stereotipov in družbeni anomiji. Vse to krepi zavedanje družbe o posledicah nenačrtovanega turizma in njegovih vplivih na naravno in družbeno okolje.

Sredi 9o-ih let prejšnjega stoletja se pojavi izraz »optimalni razvoj turizma «, ki nakazuje na iskanje ravnovesja med zmogljivostmi in ohranjanjem sedanjega stanja v okolju. To je čas, ko se začnemo še bolj zavedati nenehnih sprememb na trgu in pomena pravočasnega odziva nanje. Sistemski pristop pri načrtovanju turizma (destinacije) postaja metoda organizacije menedžmenta na vseh področjih (marketing, informiranje, transport itn.). Vse bolj se $\mathrm{v}$ načrtovanje vključuje lokalno prebivalstvo, ker se destinacijski menedžment zaveda pomena javno-zasebnega partnerstva (sobivanje, sodelovanje, soustvarjanje) (Vodeb, 2014, str. 93-94).

Eden ključnih elementov načrtovanja $\mathrm{v}$ turizmu je ciljno usmerjen proces odločanja, kjer gre za medsebojno povezane odločitve. Tudi v tem segmentu lahko ugotavljamo sistemsko naravo $v$ funkciji načrtovanja menedžmenta, saj lahko sklepamo, da medsebojna povezanost odločitev v procesu načrtovanja pomeni, da vsaka odločitev in aktivnost na nek način vplivata na vsak element $\mathrm{v}$ sistemu turistične atrakcije. Načrtovanje je tako vedno ciljno orientirano na prihodnost in neko želeno stanje, $v$ veliki meri pa gre za usklajevalno vlogo načrtovanja. V sistemu atrakcij namreč nastopa vrsta medsebojno odvisnih elementov, ki pa imajo zaradi različnih interesov, virov in ciljev tendenco razdrobljenosti, neusklajenosti in posledično neučinkovitosti. Spomnimo se, da ima turist danes zelo visoka pričakovanja. Preprosto si želi celovito turistično izkušnjo. Da bi to dosegli, mora menedžment turistične atrakcije povezati in optimizirati delovanje vseh njenih elementov, da bi zagotovil usklajeno in učinkovito delovanje atrakcije, kar bo obiskovalec doživljal kot celovito turistično izkušnjo. 
Kot v vsaki človeški dejavnosti je treba zagotoviti čim učinkovitejše delovanje na podlagi učinkovite rabe virov. Po tem se na turističnem trgu lahko primerjamo z drugimi in na podlagi tega nas ocenjuje povpraševanje (turisti). Ta funkcija se zdi izjemno pomembna, toda učinkovitost $\mathrm{v}$ delovanju določata znanje in sposobnost menedžmenta.

Iz vsega lahko sklenemo, da so dejavniki, ki vplivajo na uspeh turističnih atrakcij, organizacija in viri, proizvod (jedro atrakcije), ciljni trg in upravljanje. Za uspešno organizacijo menedžment atrakcije nujno potrebuje izkušnje z razvojem in upravljanjem atrakcij. Razpolagati mora z ustreznimi finančnimi in človeškimi viri, ki jih v procesu načrtovanja in organizacije turistične atrakcije usmerja in uporablja na najboljši možen način glede na razmere in okoliščine. Ob vsem tem se mora menedžment $\mathrm{v}$ procesu organizacije zavedati dinamike in nenehnih sprememb na trgu ter se nanje proaktivno odzivati. V sektorju turističnih atrakcij velja pravilo, da gre ponavadi za velike (zlasti začetne) finančne investicije, tveganja in sredstva, ki jih je potrebno zagotoviti, v kolikor želimo načrte izpeljati uspešno. Donosnost investicij v turizmu je lahko problematična zaradi prisotnosti veliko raznovrstnih akterjev, ki imajo različne interese (javni, zasebni, civilni sektor). Običajno pa velja, da so veliki ponudniki tudi močnejši, saj imajo pogosto kapitalsko moč, tradicijo in ugled ter podporo javnega sektorja.

Glede proizvoda, ki je jedro turistične atrakcije, veljajo enaka pravila kot $v$ vseh drugih panogah. Inovativni pristop in/ali edinstvena ideja je osnova za uspeh, to namreč poganja kolesje razvoja. Pri tem je treba vedeti, da so nujna sredstva za razvoj in kakovostno (podporno) okolje oz. storitve. Tukaj mislimo na povezljivost atrakcije z drugimi elementi turistične ponudbe, ki zagotavljajo njeno celovitost in uspeh. Lokacija, v smislu prostorske opredeljenosti, včasih tudi omejenosti, fizična dostopnost in ujemanje z obstoječo podobo destinacije - vse to so pomembni dejavniki za uspeh turistične atrakcije.

Izbira ustreznih ciljnih skupin, ki temelji na poznavanju razmer na trgu (redne tržne raziskave) in jasnem poznavanju lastne vrednosti ter lastnosti atrakcije, je $\mathrm{v}$ domeni izkušenih profesionalnih timov menedžerjev. Ti redno in inovativno spremljajo trende (družbene razmere) in sledijo zahtevam, novostim in potrebam, ki jih le-ti narekujejo. Ključnega pomena so sposobnost hitrega in učinkovitega odziva na spremembe, sledenje in natančno poznavanje zadovoljstva obiskovalcev, kajti to je najpomembnejši parameter za vsako naslednjo odločitev ali aktivnost menedžmenta. 
Pri upravljanju turističnih atrakcij se je treba zavedati učinkov tega sektorja na celotno destinacijo in turizem nasploh ter pomena povezanosti z vsemi drugimi dejavnosti in akterji v sistemu atrakcij. Na izjemno konkurenčnem turističnem trgu je uspešno upravljanje turistične atrakcije ključnega pomena.

A. Leask (2010) v svoji študiji o turističnih atrakcijah ugotavlja, da je malo akademskih objav na temo organiziranja in upravljanja atrakcij. Če že, gre za študije primerov turističnih atrakcij, ki so celovito predstavljene, toda pri tem ni razvite metodologije za spremljanje, primerjavo in ocenjevanje učinkovitosti upravljanja in organizacije atrakcij. $\mathrm{Na}$ osnovi dosedanjih raziskav meni, da je $v$ tem segmentu potencialna metoda benchmarking, saj omogoča ugotavljanje primerov dobre prakse v primerljivih okoljih in razmerah. Na podlagi tega je potrebno razviti mehanizme za identifikacijo dobrih praks in nabor indikatorjev, ki bi omogočili metodološko zanesljivo primerjavo. Vendar avtor v isti sapi opozarja, da je mednarodna primerjava lahko problematična zaradi velike raznovrstnosti turističnih atrakcij (npr. razlike pri opredelitvah in razvrščanju atrakcij od države do države). Rešitev vidi v primerjavi izhodiščnih podatkov, s katerimi bi se poiskalo ključne prioritete znotraj širše perspektive in skupnih koristi za atrakcije. Ne obstajajo namreč univerzalni upravljavski pristopi in rešitve, ki bi jih lahko implementirali v vseh okoljih. Univerzalne primerjave so možne le na podlagi števila obiskovalcev, lastništva atrakcij in njihove velikosti. Toda take primerjave ne povedo veliko. Vsaka atrakcija upravljavska orodja in pristope uporablja glede na svoje vire, značilnosti in kontekst, v katerem deluje. Pa vendar obstajajo nekakšne generalne smernice za učinkovitost menedžmenta, ki veljajo v vseh vrstah, velikostih in vsebinah atrakcij. To je pomen zagotavljanja zadovoljstva obiskovalcev skozi razumevanje njihove motivacije, razvoj proizvoda ter sodelovanje med akterji v sistemu atrakcije. Razlike so med upravljavskimi praksami v javnem in zasebnem sektorju, narava atrakcije prav tako odreja upravljavske pristope (prim. zabaviščni park ali krajinski park), toda predvsem je treba opozoriti na razlike v sposobnosti menedžmenta, znanju in praksi upravljanja turistične atrakcije. Največji izziv turističnih atrakcij pa je $v$ doseganju ravnovesja med zaščito virov in njihovo avtentičnostjo. Pretirana osredotočenost na proizvod ali na drugi strani na trg ne zagotavlja optimalnih rezultatov na dolgi rok. Izkazalo se je, da sta bolj kot karkoli zanesljiva dejavnika učinkovitega upravljanja sodelovanje $z$ drugimi sektorji ter razvoj ustreznega upravljavskega pristopa vsake posamezne atrakcije. 
Mason (2015) meni, da je upravljanje turistične atrakcije predvsem način za upravljanje okoljskih in družbenih vplivov turizma skozi izobraževanje (vedenje obiskovalcev, zaposlenih v turizmu in lokalne skupnosti) in regulacijo (števila obiskovalcev, gostote prometa, nosilne zmogljivosti, prilagajanje atrakcije obisku in interpretacija atrakcije).

Vedeti je treba, da vsa priporočila in tehnike za učinkoviteje upravljanje turističnih atrakcij, od sodelovanja med akterji do trajnostnega koncepta upravljanja atrakcij, ne prinašajo nujno želenih rezultatov in je potrebno vsak primer obravnavati skrbno, glede na značilnosti atrakcije, ter iskati ravnovesje med doseganjem vseh vrst učinkov.

\section{Valorizacija turističnih virov}

Odločitev, da se ustvari turistično atrakcijo, je vezana na željo (interes) posameznika ali skupine ljudi, da zagotovi javni dostop do nekega vira. Interes sam po sebi ni dovolj, potrebna je aktivnost, da pride do potrebnih dejanj in postopkov, ki sprožijo proces pretvarjanja vira v atrakcijo.

Dokler se za določenim virom $s$ strani povpraševanja ne pojavijo potrebe, interesi ali zahteve in preden se v proces ne vključi menedžment, ki oblikuje ponudbe, lahko govorimo le o potencialnih turističnih virih. McKercher in du Cros (2002, str. 172) menita, da turistični vir postane turistična privlačnost, ko »pripoveduje zgodbo, oživi znamenitost, omogoča udeležbo pri doživetju, naredi doživetje pomembno za turista, se osredotoča na avtentičnost in kakovost «. Tako viri ostajajo, če jih ne razvijamo, skriti potenciali.

Šele z ustrezno turistično valorizacijo lahko turistične vire transformiramo v turistične privlačnosti, brez nje pa ostajajo na ravni komparativnih prednosti oz. potencialnih turističnih virov. Pri tem ima ključno vlogo sposobnost menedžmenta destinacije, ki je zadolžen za valorizacijo turističnih virov. Ker ne gre za enkratno dejanje, pač pa za dolgoročen proces, je valorizacija turističnih virov proces, ki ga lahko razdelimo po fazah.

Proces valorizacije turističnih virov poteka po spodaj opisanih korakih (Vodeb, 20I4, str. 2I-23):

I. Prepoznavanje - identifikacija vira je faza, ko zaznamo nek vir kot turističen na podlagi različnih impulzov iz okolja. Eden od možnih indikatorjev je turistično povpraševanje (turistov, obiskovalcev), ki nakazuje interes turistov za določen vir. Interes povpraševanja lahko zaznamo posredno in neposredno, spontano in načrtno (npr. z izvedbo tržne raziskave med potencial- 
nimi obiskovalci). Najzanesljivejši dejavnik v tem segmentu je motivacija obiskovalcev. Naslednji možen indikator so trendi, saj gre za predvidene spremembe, ki jih ugotavljamo z napovedmi (Lomine in Edmunds, 2007) in lahko opazujemo, kako se v času spreminjajo. V določenem trenutku trendi lahko »opozorijo «, da je prišel čas za turistični vir, ki ga imamo v svojem okolju. Impulz za identifikacijo turističnega vira je lahko tudi okolje samo (npr. lokalna skupnost ali turistično gospodarstvo), ki zazna nek vir kot turističen glede na situacijo pri tekmecih. Zaznavanje (odkrivanje) turističnega vira nikoli ni samoumevno, lahko pa je popolnoma naključno. Včasih je zaznavanje vira, ne glede na njegovo stalno prisotnost v prostoru, zelo težavno, saj ga v surovi obliki tudi sami ne vidimo na način, kot ga želi videti obiskovalec. Jasno je, da se turistični potenciali spreminjajo skozi čas, predvsem so pogojeni z družbenimi spremembami in nekaj, kar v preteklosti niso imeli za potencial, v sedanjosti lahko predstavlja veliko priložnost za razvoj v turističnem smislu. Tako sta bila nekoč pomembnoejša morje in sonce, sedaj so vse bolj kulturna dediščina, tradicija in kulinarika. Nekoč so veliko turističnega potenciala pripisovali obmorskim krajem z blago klimo, sedaj pa adrenalinskim parkom, državnim mejam, ki predstavljajo turistične atrakcije in podobno.

2. Analiza - vrednotenje vira je faza, ko na podlagi prepoznanega turističnega potenciala pričnemo $z$ njegovim vrednotenjem oz. analizo. Gre namreč za introspekcijo lastnih potencialov z več zornih kotov, kar bo posledično menedžment pripeljalo do zrelega zavedanja o konkretnem turističnem viru. Analiza turističnega vira je v osnovi vrednotenje prepoznanega vira na podlagi različnih kriterijev, pri čemer ne gre prezreti dejstva, da moramo prepoznani vir nujno umestiti v že obstoječi okvir nekega prostora (turistične destinacije), njenega znanega turističnega proizvoda, obstoječe infrastrukture in to v natančno določeni življenjski fazi. To priča o kompleksnosti in zahtevnosti te aktivnosti. Pri vrednotenju vira so ključnega pomena njegove specifične lastnosti in kakovost, ki posledično vplivajo na oblikovanje podobe atrakcije v očeh turistov. Vrednotenje zaznanega turističnega vira je tako odvisno od subjektivne percepcije (lastne vrednosti) in vrednosti virov konkurence (primerjava) ter projekcije razvoja turističnega vira v prihodnje (glede na povpraševanje in trende). Pri vrednotenju vira igrajo ključno vlogo njego- 
va edinstvenost, redkost, dragocenost, posebnost in unikatnost (najstarejša trta na svetu ipd.) kakor tudi ujemanje in vpetost $\mathrm{v}$ obstoječo strukturo destinacije ter njene obstoječe privlačnosti. Nasploh se je že v tej fazi razvoja atrakcije potrebno vprašati, »kdo smo in kaj imamo «, saj je identiteta atrakcije osnova za razvoj podobe atrakcije, ki sledi v naslednji fazi procesa valorizacije. Poleg tega pa moramo že na tej točki vedeti, kaj si obiskovalci želijo ter kaj si bodo želeli v prihodnje, da bi turistični vir ustrezno ovrednotili.

3. Artikulacija podobe vira je faza, ko se na podlagi vrednotenja iz predhodne faze oblikuje (artikulira) podoba turistične privlačnosti v nastajanju. Podoba atrakcije je nekaj, kar lahko podrobno opišemo, izrazimo z lastnostmi, zahteva pa temeljito poznavanje, razumevanje in odnos do turističnega vira. Podoba turistične privlačnosti je pomembna za konkurenčnost in uspeh na turističnem trgu, saj bo predstavljala ključen element pri izbiri in odločitvi turista za konkretno destinacijo. Podoba je skupek idej, prepričanj in vtisov, ki jih ima posameznik o določeni destinaciji ali atrakciji in vključuje tako objektivne - subjektivne, funkcionalne (otipljivejše, jasnejše) - psihološke (abstraktne) kakor tudi posebne (unikatne) turistične lastnosti (Krašna, 2007).

$\mathrm{Za}$ uspeh in konkurenčnost turistične privlačnosti je kritičen razkorak med našo lastno podobo in podobo atrakcije v očeh turistov. Večji kot je ta razkorak, slabša je bila artikulacija podobe, kar povzroča težave s prepoznavnostjo obiskovalcem na turističnem trgu in vpliva na njeno pozicijo na trgu (konkurenčnost). Do tega razkoraka pride, če oblikovanje lastne podobe in podobe, ki jo zaznavajo turisti, poteka neusklajeno, če preveč temelji mo na naših lastnih zaznavah, čustvih in prepričanjih. Biti objektiven, strokoven, stopiti iz okvirja in gledati na turistični vir realno pomeni videti stvari v drugačni luči in ne le z lastne perspektive, to je ustrezen način usklajevanja podobe vira, ki je na poti, da postane privlačnost.

Velika nevarnost pri artikulaciji podobe je neredko posnemanje uspešnih turističnih privlačnosti, saj pri tem še bolj zameglimo identiteto in razlikovalne lastnosti privlačnosti, kar je dodaten argument za nejasnost podobe, ki dolgoročno zagotovo pelje v neuspeh. Velikokrat se namreč ujamemo v zanko pretiranega približevanja konkurenčnim turističnim privlačnostim, zmotno misleč, da nam bo znana, preverjena podoba lažje utrla pot do 
prepoznavnosti in vrednostnega sistema ciljnega segmenta obiskovalcev. Pri tem seveda zanemarjamo lastno identiteto in lastnosti svoje privlačnosti, kar na podobo vpliva kot razredčilo in ustvarja zbegano identiteto, nejasno podobo ter s tem vse pogoje za nekonkurenčnost na turističnem trgu. Zato velja pri tem zasledovati lastno identiteto in pristnost, kar zahteva tudi določeno mero drznosti in tveganja.

4. Komunikacija podobe vira je faza v procesu valorizacije turističnega vira, ko menedžment oblikovano (artikulirano) podobo komunicira ciljni publiki skozi različne distribucijske kanale. Gre za informiranje o podobi, njeno predstavljanje, ki pa pomeni komunikacijo, kar je obojestranski prenos sporočil. Obojestranskost tega procesa pomeni, da ne gre le za pasivno posredovanje podobe ciljnemu (potencialnemu) trgu obiskovalcev, pač pa pozorno spremljanje odziva obiskovalcev (kar je izjemno pomembno) in upoštevanje te povratne informacije, ki nam jo ciljna publika posreduje kot odgovor na našo informacijo. $\mathrm{Na}$ podlagi relevantnih povratnih informacij lahko prilagodimo, uskladimo in korigiramo podobo turističnega vira v fazi nastajanja, kar je učinkovitejše in smiselnejše kot v vseh naslednjih fazah njenega razvoja. V tej fazi valorizacije turističnega vira gre za pomembno interakcijo med ponudbo in povpraševanjem, ki svoje zaznave o podobi privlačnosti pošiljata druga drugi. Pri sporočanju podobe in njene interpretacije ciljnemu trgu obiskovalcev temeljimo na doslednosti in zanesljivosti, pri tem pa je izbira distribucijskih kanalov zelo odvisna od segmenta obiskovalcev, ki jim je privlačnost namenjena. Drugače povedano, pomembno je vedeti, kakšno informiranje je relevantno za ciljno publiko, kar sodi v področje marketinga atrakcije. Vrednostni sistem, navade in vedenje potencialnih obiskovalcev predstavljajo pravo zakladnico informacij za menedžment, saj se predvsem na podlagi tega odločajo o izbiri.

5. Razvoj turistične privlačnosti je naslednja faza v procesu valorizacije turističnih virov in predstavlja razvoj privlačnosti oz. njegovo vključevanje v obstoječo in novo turistično ponudbo. $\mathrm{Na}$ podlagi obstoječih turističnih proizvodov sestavljamo (dograjujemo) nove in drugačne turistične proizvode, ki so v skladu s povpraševanjem in pričakovanjem ciljnih segmentov obiskovalcev ter prav tako uglašeni z našimi lastnimi viri, njihovo zmogljivostjo, stopnjo razvoja in kakovostjo. Tukaj naj bi šlo za smisel- 
ne vsebinske kombinacije turističnih proizvodov, ki obiskovalcu dopuščajo individualno izbiro in oblikovanje integralnega turističnega proizvoda po lastnem okusu. Lahko bi rekli, da ta faza pravzaprav nenehno poteka oz. je del življenjskega cikla vsake nove turistične privlačnosti, saj nanj gledamo kot na turistični proizvod. Razvoj turistične privlačnosti je namreč tudi sam po sebi proces, ki nujno spremlja vse faze življenja neke turistične privlačnosti in se preliva s procesom načrtovanja in upravljanja privlačnosti. Skrbno spremljanje odziva na strani povpraševanja in uglaševanje teh zahtev z nosilno zmogljivostjo (družbeno, okoljsko in ekonomsko) ter racionalnimi cilji menedžmenta glede na posamezni vir predstavljata modrost uspešne trajnostne valorizacije turistične atrakcije. Nedvomno je izziv v iskanju ravnotežja med cilji in zmožnostmi na dolgoročni trajnostni osnovi turističnega razvoja.

6. Trženje turistične privlačnosti je zadnja faza procesa valorizacije turističnih virov, kjer pride do dokončne transformacije vira $\mathrm{v}$ privlačnost, saj šele takrat dejansko zadovoljimo oba pogoja za delovanje turistične privlačnosti - to sta dostopnost in prepoznavnost na turističnem trgu. Pri tem lahko uporabljamo standardno orodje $\gg$ marketing mixa $\ll, \mathrm{z}$ upoštevanjem vrednostnega sistema ciljnega segmenta (doslej naj bi ga že dodobra razumeli), ter oblikujemo take načine trženja privlačnosti, da zagotavljamo uglašenost potreb trga z naravo podobe vira, ki je sedaj postal privlačnost. V vseh fazah, posebno pa v tej, je potrebno zagotoviti aktivno vlogo vključevanja vseh akterjev, ki sodelujejo v sistemu atrakcije. Vedno bolj postaja jasno, da je lokalna skupnost sestavni del privlačnosti/destinacije $v$ vseh svojih dimenzijah. Ko pa nastopi faza trženja turističnega vira, je ključnega pomena interni marketing, ki obsega vse notranje akterje in nosilce turistične privlačnosti: turistično gospodarstvo, prebivalce, lastnike, upravo, predstavnike varstva naravne in kulturne dediščine itn. (Brezovec, Sedmak in Vodeb, 2007). Vsi ti predstavljajo privlačnost, njene lastnosti, identiteto in zgodbo, ki jo morajo ne samo dobro poznati, ampak ponotranjiti, zato posnemanje uspešnih zgodb predstavlja največje tveganje, saj smo lahko izvrstni, prist$\mathrm{ni}$ in originalni le $\mathrm{v}$ tistem, kar pravzaprav smo - v svoji lastni podobi.

Na podlagi vsega tega lahko sklenemo, da je turistični vir dobrina, ki se jo prepozna kot turistično, ko v njej prepoznamo nek turistični po- 
tencial, ta pa je pogojen s časom in razmerami v družbi, ki nakazujejo na »uporabnost« (koristnost) te dobrine za turistične namene. V tem kontekstu, pred procesom valorizacije, turistični vir predstavlja komparativno ali primerjalno prednost, ki še ni turistično valorizirana, kar pomeni, da še ni aktivirana kot turistična privlačnost, v katero niso vloženi znanje, sredstva ali napori menedžmenta. Turistični vir kot tak predstavlja zasnovo privlačnosti, ki obiskovalcem še ni dostopna, se ne trži v turistične namene in je ne poznajo.

Za razliko od turističnega vira pa je turistična privlačnost že turistično valorizirana, »postavljena« na vidno mesto na turističnem trgu, obiskovalci jo prepoznajo, je dostopna (fizično in informativno) in kot taka predstavlja osnovni motiv obiska v neki turistični destinaciji. Zaradi vložka znanja, sredstev in sposobnosti menedžmenta ter vseh aktivnosti, ki so v procesu valorizacije zahtevane, turistična privlačnost predstavlja konkurenčno prednost, po kateri je destinacija prepoznavna na trgu. To prepoznavnost seveda črpa iz specifičnih lastnosti in identitete vira, na podlagi katerega je nastala, ki pa se v tej obliki zrcali v podobi privlačnosti, ki jo kot tako zaznavajo obiskovalci in primerjajo (ocenjujejo) med številno množico podobnih ali manj podobnih privlačnosti, vezano na svoj motiv potovanja. Torej je turistična privlačnost vir z dodano vrednostjo, ta pa je rezultat sposobnosti menedžmenta in vseh njegovih aktivnosti v procesu turistične valorizacije.

\section{Atrakcija kot turistični proizvod ali turistična izkušnja}

Če se opremo na Magaševo (1997) trditev, da ima destinacija proizvodno funkcijo (ponudbe počitnic) in na podlagi optimalne kombinacije fiksnih in variabilnih dejavnikov "proizvaja” destinacijski turistični proizvod, bi lahko rekli tudi, da se proizvodna funkcija turizma odraža v dejanju turistične potrošnje. Zaradi tega je v literaturi in teoriji turizma toliko ekonomske dimenzije turizma, saj na turizem generalno (prevečkrat) gledamo zgolj kot na gospodarsko dejavnost. Toda turistični proizvod ima visoko stopnjo kompleksnosti pa tudi specifike, ki so značilne samo zanj. Npr., za turistični proizvod velja, da je neotipljiv, sestavljen iz večjega števila posameznih proizvodov in storitev, kot je integralni turistični proizvod, ki je značilen za destinacijo in sodobno turistično ponudbo. Turistični proizvod sestavljajo privlačnost in dostopnost kraja ter turistične zmogljivosti $\mathrm{v}$ tem kraju. $Z$ vidika turista je turistični proizvod celotno doživetje od trenutka, ko zapusti kraj stalnega bivališča, do trenutka, ko se vrne vanj (Mihalič 2002).

Nadalje, visokokakovostne storitve lahko uspešno »prodajajo《 tisti, ki obvladajo zlasti čustveno komponento odnosa do turista; tako morajo 
biti zaposleni sposobni delovati čustveno, ker to zahteva kakovost storitve, in racionalno, ker to zahteva ekonomski izračun storitve. Iz teh opredelitev lahko vidimo, da je turistični proizvod izjemno kompleksen fenomen, ki temelji pretežno na odnosih, čustvih, vrsti zaznav in čutil, kar pa seveda sodi v nematerialno sfero proizvoda kot takega. Gre za mešanico otipljivih in neotipljivih elementov ponudbe, ki obiskovalcu ponuja določene koristi in možnost za zadovoljitev njegovih potreb in pričakovanj. Pri tem so zaposleni del tega proizvoda, saj s svojim odnosom in vedenjem vplivajo na obiskovalca in njegovo doživetje turističnega proizvoda. Obiskovalci pa so prav tako aktivno vključeni v proces konzumacije turističnega proizvoda s svojim lastnim odnosom - percepcijo in dinamiko le-tega. Turističnega proizvoda $\mathrm{v}$ tem segmentu ni možno standardizirati, saj ko gre za odnose (npr. med zaposlenimi in obiskovalci), ne moremo predpisati idealnega merila, zapovedati količine in podobno, kajti odnosi so povsem nematerialni. So pa za turistični proizvod značilne konzumacija na mestu samem, nezmožnost skladiščenja in pokvarljivost blaga, zato je ravnovesje med ponudbo in povpraševanjem zelo pomembno. Poleg obiskovalca in zaposlenega $\mathrm{v}$ turizmu pa tudi okolje proizvoda predstavlja njegov pomembni sestavni del. Tukaj mislimo na vzdušje in ambient, $\mathrm{v}$ katerem se turistični proizvod konzumira ali kupuje. Ne smemo pozabiti, da obiskovalec turistični proizvod doživlja in zaznava z vsemi svojimi čutili. Ta multisenzoričnost (Scarles, 2010) v turizmu je zadnje čase tudi pomemben vidik razvoja turistične teorije.

Konkurenčnost atrakcije temelji na njeni sposobnosti, da obiskovalcem ponudi edinstveno, drugačno, posebno, nepozabno doživetje. Pri tem je turistične proizvode seveda lažje cenovno ovrednotiti kot doživetja. Del turistične potrošnje predstavljajo številne nematerialne (neotipljive) storitve, ki oblikujejo doživetje atrakcije. K temu veliko prispevajo prav zaposleni v turizmu, ki s svojo prisotnostjo in dejavnostjo tkejo tako pretanjeno turistično storitev. Tudi v drugih storitvenih dejavnostih se vse bolj zavedajo velikega pomena zaposlenih pri izvrstnosti storitev (ang. exceptional customer service), ki imajo potrebne sposobnosti in odnos do strank. Zaposleni so ključni dejavnik uspešnosti in hkrati največji izziv za menedžment. Danes ni problem na trgu dobiti ljudi, problem je dobiti ljudi s pravim odnosom do dela in strank in to se $\mathrm{v}$ turizmu še nazorneje kaže, ker gre za dejavnost, ki temelji na odnosu (Vodeb, 20I4, str. I2I-I22).

Atrakcijo seveda načrtujemo, razvijamo in upravljamo kot turistični proizvod, saj je njen namen turistični, toda pri tem upoštevamo njene specifike in kompleksnost, ki kličejo po previdni obravnavi. Namreč, noben proizvod ne omogoča doživetja, omogoča le priložnost zanj. Doži- 
vetje je izključno v domeni obiskovalca, temelji pa na proizvodu. Pri tem je vloga obiskovalca več kot očitna, zavedanje, da je potrebno zelo dobro poznati obiskovalca, pa je korak bližje učinkovitosti in uspešnosti v turizmu.

Kot je razvidno iz slike 3, vsako turistično doživetje turističnega proizvoda ( $v$ našem primeru atrakcije) sproža določene učinke ali rezultate teh doživetij, ki pa so pomemben dejavnik v razumevanju vedenja in pričakovanj obiskovalca. Vsak dogodek (v našem primeru izkušnja turistične atrakcije) v posamezniku spodbudi različne odzive, ki so odvisni od njegovih vrednot, prepričanj, preteklih izkušenj, motivov in pričakovanj. Ta proces oblikuje njegovo zaznavo, mnenje in razlago doživetja. Vse to spremljajo njegove fizične zaznave, občutki in mišljenje, ki potem spodbudijo njegova specifična dejanja in vedenja. Na ta način prihaja do spremembe njegovih izkušenj, novih doživetij, drugačnih zaznav, kar je posledica globljega razumevanja sebe in sveta, ter nastajanja novih pomenov in odnosov, ki jih gradi na podlagi novih dogodkov in izkušenj.

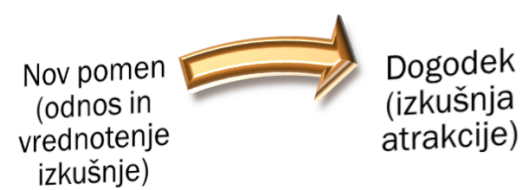

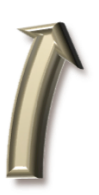

Globje razumevanje sebe in sveta

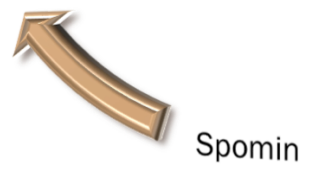

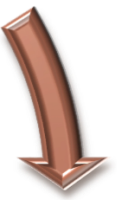

Reakcija (odnos do izkušnje)

\section{Slika 3: Tok turistične izkušnje}

Vir: avtorica.

V kolikor drži domneva Paga in Connellove (2006), da je turistična izkušnja sestavljena iz ene tretjine turističnega proizvoda, ene tretjine turistične storitve in ene tretjine odnosov, ki nastajajo v turizmu, lahko vidimo, kako pomemben delež v turistični izkušnji pravzaprav imajo odno- 
si. To ni ravno $\mathrm{v}$ skladu $\mathrm{z}$ dejstvom, da menedžment $\mathrm{v}$ turizmu še zmeraj največ investira $\mathrm{v}$ opremo, tehnologijo in druga materialna sredstva svoje ponudbe, medtem ko človeški dejavnik zanemarja. A to je kratkoročna rešitev, saj brez človeka ni turizma.

Konkurenčnost atrakcije je zelo odvisna od zaposlenih, toda ne samo od njihovega znanja, veščin in sposobnosti, ampak zlasti od odnosa, ki ga imajo do obiskovalcev, njihove delovne etike in dostopnosti. Turizem je delovno intenzivna panoga in zaposluje veliko ljudi tam, kjer človeka ne more zamenjati stroj. Zato je odnos zaposlenega do dela, gosta in sodelavcev ključnega pomena in prispeva h kakovosti turistične storitve. Tem odnosom lahko rečemo mehki del kakovosti turistične ponudbe, ki ga ne moremo materializirati in ki prihaja od zaposlenih (Vodeb, 2014, str. I2I).

Turistična atrakcija kot proizvod ali turistična izkušnja je z vidika obiskovalca zmeraj celota, $\mathrm{z}$ vidika individualnega ponudnika, ki nastopa v povezavi z atrakcijo (hotelir, letalski prevoznik, ponudnik rent-a-car, muzej ipd.), pa je to posamezna storitev. Zaradi te disparitete $\mathrm{v}$ zaznavah na strani ponudbe in povpraševanja je potrebno zagotoviti sodelovanje in usklajevanje vseh akterjev v sistemu atrakcije, to je ključni del njenega uspeha. Obiskovalec vidi delni turistični proizvod, kadar na strani ponudbe ne dosegamo pogojev za celovito turistično doživetje, kar pomeni, da so akterji nekoordinirani, nepovezani in $s$ tem ne omogočajo celovitosti doživetja, ki je cilj turističnega obiska. Menedžment je tukaj torej v funkciji skladatelja in dirigenta, posamezni akterji pa so posamični glasbeniki, vsak na svojem področju lahko izjemni virtuozi. Ne glede na njihovo vrhunskost in kakovost bo uspeh izostal, dokler ne dosežemo povezanosti in usklajenosti njihovega skupnega delovanja (nastopa). To je tudi značilnost turistične izkušnje.

$\mathrm{Ne}$ čudi torej ugotovitev iz prejšnjega poglavja, da je učinkovitost in uspeh turističnih atrakcij v doseganju kakovostnih, smiselnih povezav in sodelovanja znotraj verige turističnega proizvoda oz. sistema atrakcije. Na podlagi te učinkovitosti se lahko meri učinkovitost menedžmenta atrakcije. 



\section{Trendi v razvoju turističnih atrakcij}

Pisati o trendih v turizmu je zmeraj nehvaležno, po drugi strani pa je to izziv in nuja, s čimer se spopadajo tisti, ki v turizmu načrtujejo, razvijajo in upravljajo turistične atrakcije. V poglavju o zgodovinskem pregledu razvoja turističnih atrakcij smo ugotavljali, da je skozi čas možno z gotovostjo potrditi dve konstanti, kadar govorimo o turističnih atrakcijah. Ti sta pomen, ki ga družba pripisuje turističnim atrakcijam, in dostopnost (časa, denarja, informacij) turističnih atrakcij. Veliko je razlogov za naraščanje pomena turističnih atrakcij v turizmu. Predvsem so ti razlogi v gospodarskem razvoju, pomenu prostega časa v družbi (etika prostega časa), napredku v tehnologiji, transportu, medijih in moči marketinga, napredku v izobrazbi in nasploh družbenih spremembah.

Trendi so predvidene spremembe, ki jih identificiramo $z$ napovedmi (Lomine in Edmunds, 2007). Ti nastanejo zaradi pritiskov turistične industrije in sprememb v povpraševanju, ki pa so odraz razmer v družbi. Šturm in Ruzzier (20IO, str. 20) se sprašujeta, ali je segmentacija turističnega trga v teh razmerah še mogoča, saj naj bi potrošništvo nenehno generiralo nove segmente obiskovalcev. Kakorkoli že, očitno je zanesljiva le sprememba, a to lahko obvladujemo le s spremljanjem in z razumevanjem predhodnih dogodkov.

Sodobni trendi, ki vplivajo na atrakcije, so po mnenju Johnsa in Hoseasona (2001):

- koncept popotnika in ne turista,

- športne (aktivne) počitnice,

- neokrnjena narava, 
- zdrav način življenja,

- skrb za zdravje - preventivno in proaktivno delovanje posameznika,

- pustolovski turizem,

- ekoturizem,

- podaljšane sezone in obisk izven sezon,

- poglobljena vrednost doživetja.

Buhalis in Costa (2006) predvidevata, da bo turizem v prihodnje doživel največ sprememb zaradi novih trendov v vedenju turistov. Pričakovani novi proizvodi in atrakcije bodo terjali spremembe v strukturi organizacije in na operativnem področju zagotavljanja storitev. Učinkovito in proaktivno prilagajanje spremembam $v$ zunanjem okolju sistema atrakcije bo postalo še pomembnejše, kar bo vplivalo na proces načrtovanja, upravljanja razvoja atrakcije in njenega trženja.

Globalni dejavniki bodo imeli v prihodnje zelo velik vpliv na nadaljnji razvoj atrakcij in s tem povezane vsebine. Gospodarski in politični dejavniki bodo še naprej zelo vplivali na razvoj, saj so zelo povezani z družbenimi in okoljskimi spremembami. Tudi tehnološki dejavniki, ki že od industrijske revolucije naprej predstavljajo za družbo pomembno gonilo sprememb, bodo tudi v prihodnje oblikovali stanje sodobnega turizma. Z razvojem tehnologije so podnebni, okoljski in geografski dejavniki vendarle predvidljivejši, saj je mogoče zanesljivejše spremljanje in razumevanje dogodkov na tem področju. Demografski dejavniki za razvoj turizma predstavljajo ključne pogoje, ker brez človeka ni turizma. Socio-kulturni dejavniki v sodobnem času pa so tudi kar hitro spreminjajoče se področje, kar je posledica globalizacije, internacionalizacije in mobilnosti (Vodeb, 2014).

Spremembe so edina zanesljiva stalnost: spreminjajo se obiskovalec, njegove zahteve, vedenje in pričakovanja, ostaja pa potreba po potovanju ter iskanju drugačnosti in sprostitve. Turizem se bo tako še naprej razvijal $\mathrm{v}$ smeri atrakcij, ki ponujajo doživetja in izkušnje, ne pa njihovo pasivno obiskovanje in konzumacijo v materialnem smislu (stavbe, mesta, zabaviščni parki ipd.). Te napovedi veljajo izključno za zahodni svet in ne za Latinsko Ameriko, Afriko, arabski svet in Azijo. Za sodobni čas in čas, ki je pred nami, bo značilno poglobljeno zavedanje sebe in sveta zaradi lažjega dostopa do informacij in sofisticirane tehnologije. Število turističnih potovanj se povečuje skupaj s številom zaposlenih v turizmu. Večji interes ljudje izkazujejo za tuje kulture in spoznavanje tamkajšnjih lokalnih razmer. V ospredje spet prihaja izobraževalna funkcija turističnega potovanja, ko ne gre več za površen odnos, ampak za poglobljen, pristen odnos 
do domačinov in njihove kulture. Vse bolj postaja jasno, da so turistični viri omejeni, zato narašča zavedanje o nujnosti varovanja narave, trajnostni turizem pa postaja paradigma sodobnega turizma, pri čemer stakakovost okolja in kakovost življenja skupnosti na prvem mestu. Zelene, zdrave in aktivne oblike prostočasnih dejavnosti privabljajo vse večje število ljudi. Enako je z ustvarjalnimi in s produktivnimi vrstami prostočasnih dejavnosti (npr. volonterski turizem). Potovanja postajajo del procesa osebnostne rasti in razvoja posameznika in so velikokrat naravnana kot potovanja z razlogom. Stopnja izobrazbe narašča, kar zelo vpliva na nakupno vedenje in potrebe, ki jih imajo ljudje kot turisti. Populacija se stara, ljudje se poročajo pozneje, pozneje imajo tudi otroke, pozneje se zaposlijo in delajo dlje. Družine se odločajo za manjše število otrok, veliko je tudi enostarševskih družin, zaradi česar so posledično lahko višji prihodki na člana družine, ni pa to nujno, saj enostarševske družine lahko pomenijo tudi nižji prihodek na člana. To vpliva na kakovost življenja in tudi na preživljanje prostega časa. Čeprav je domnevno več prostega časa, se nam zdi, da ni tako, ker smo zasuti s »potrebami« sodobnega življenja, kot so internet, televizija, mobilna telefonija itn. Za ljudi prosti čas postaja vse dragocenejši, turistična potovanja pa na lestvici človekovih potreb še vedno ohranjajo prioriteto. Za družbo in skupnost vse bolj priljubljene in pomembne postajajo prostočasnih dejavnosti. $V$ turizmu je vse prisotnejša visoka kakovost $\mathrm{v} v$ seh vidikih ponudbe, še zlasti na področju človeških odnosov (kakovostna, vrhunska turistična storitev, prilagojena posamezniku). Narašča število ljudi, ki so za kakovostno turistično izkušnjo pripravljeni plačati več. Zdravje posameznika predstavlja prioriteto in človek vse bolj razume svojo vlogo pri tem, zato ne išče rešitev zunaj sebe, ampak se zaveda, da mora zase poskrbeti sam in tako čim dlje ohranjati vitalnost in zdravje. Za turiste je še vedno zelo privlačen zdravstveni turizem, ki obsega spa, wellness, talasoterapijo, fizioterapijo in podobno. V našem okolju poleg oblik zdravljenja klasične medicine vse bolj narašča zanimanje za alternativne oblike zdravljenja, zato so na voljo programi meditacij, akupunkture, tehnik dihanja, masaž, programi »stress control «, sprostitveni programi in podobno (Vodeb, 2014.).

Zanimiva je napoved Masona (2015, str. 178 ), ki meni, da bo v prihodnje načrtovanje $\mathrm{v}$ turizmu vse bolj v rokah zasebnega sektorja ter da bodo lokalne skupnosti veliko bolj vključene $v$ proces načrtovanja in razvoja turizma. Predvideva veliko več oblik partnerstva in mreženja med različnimi akterji v turizmu, kar je spodbudno.

A. Leask (2008) verjame, da trendi nakazujejo potrebo, da se atrakcije približa širši publiki na način, da se jim ponudi kombinacije proizvodov 
in storitev $z$ več izbire. Tudi ta avtorica je mnenja, da se spreminjajoči se vzorci preživljanja prostega časa in sredstev zanj odražajo v vrstah atrakcij, ki si jih obiskovalci želijo. Zato bo potrebno angažirati veliko naporov $\mathrm{v}$ inovacije s področja atrakcij, ki bodo zadovoljile nove generacije obiskovalcev, zlasti njihove potrebe po celovitih turističnih doživetjih.

Benckendorff (2006, str. 204) je prepričan, da so demografski dejavniki najpomembnejši v skupini družbenih trendov, ko gre za trende s področja turističnih atrakcij. Mednje prišteva upad števila tradicionalnih družin; staranje populacije; kulturno raznolikost; multikulturalizem, ki je posledica globalizacije; krajša, večkratna potovanja; naraščanje zahtevnosti obiskovalcev, ki iščejo kakovost doživetja; duhovnost; osebnostno rast in družinske vrednote. Med tehnološke trende uvršča računalniške rezervacijske sisteme; interaktivno multimedijo (za simulacije in virtualno resničnost) in spletno tehnologijo (za virtualne oglede, rekonstrukcijo dogodkov, kulturne dediščine ali za spontane odločitve o rezervacijah »last-minute «). Gospodarski trendi so po njegovem nadaljevanje širjenja globalizacije in globalne konkurenčnosti ob sočasnem iskanju avtentične osebne turistične izkušnje; spremembe v višini sredstev, namenjenih za turistične obiske in prosti čas; zavedanje turističnega gospodarstva, da število obiskovalcev ni najpomembnejša dimenzija uspeha atrakcije, pač pa prihodki od atrakcije; predvideva tudi naraščanje števila bogatih pripadnikov srednjega družbenega razreda, ki potujejo v Indijo in na Kitajsko. Te ugotovitve se nanašajo pretežno na zahodni svet, zato teh trendov nikakor ne gre posploševati. Med okoljske trende (Benckendorff, 2006) všteva naraščanje zavedanja o nuji varovanja naravnih virov zaradi ranljivosti le-teh ter krepitev ekološke zavesti in etike na strani ponudbe ter povpraševanja. Te navedbe so sicer v nasprotju s praktičnimi primeri držav na »razvitem zahodu «, ki so veliki onesnaževalci in pogosto ne spoštujejo ekoloških standardov zaradi ekonomskih razlogov in še zmeraj spornih kratkoročnih, netrajnostnih razvojnih konceptov. Politični trendi so po večini »obarvani«s skrbjo za varnost pred terorizmom, saj so tarča teroristov prepogosto turistična središča in priljubljene turistične destinacije. Varnost tako v turizmu spet pridobiva na pomenu. Ta je imela zmeraj pomembno vlogo, že zaradi tega, ker turizem sodi v krog nenuj nih aktivnosti in potreb človeka. Globalizacija, internacionalizacija in sodobna tehnologija na eni strani omogočajo vse več turističnih potovanj, politične razmere v svetu na drugi strani pa imajo izjemen učinek nanje. 


\section{Zaključek}

Potreba po tej knjigi se je pojavila tudi na podlagi dejstva, da v slovenskem prostoru kritično primanjkuje znanstvene literature s področja turističnih atrakcij. Na splošno so znanstvene razprave slovenskih avtorjev s tega področja dokaj skope, tudi zaradi usmeritev in potrebe objavljanja znanstvenih besedil $v$ angleškem jeziku zaradi mednarodne odmevnosti raziskovalcev. Ne glede na to so v zadnjih desetih letih obravnave turizma vse prisotnejše tudi $v$ našem govornem okolju, kar pozitivno vpliva na razvoj strokovne in znanstvene terminologije v turizmu. Osrednji motiv nastanka te knjige je inovativnost pristopa, kjer se k problematiki pristopa na sistematičen in celovit način, povezuje spoznanja in ugotovitve predhodnih študij ter se na podlagi nekaterih bistvenih povezav oblikuje nova spoznanja in ugotovitve.

Osrednji cilj pričujoče znanstvene monografije je bil opredeliti osnovne pojme obravnave $\mathrm{z}$ jasno razločitvijo med turističnimi viri in turističnimi atrakcijami zaradi funkcionalnih težav v upravljanju in delovanju turističnih atrakcij v praksi. Koncept turistične atrakcije je obravnavan v luči družbenega konteksta in na podlagi kritičnih teorij turizma temeljnih avtorjev, da bi jasneje predstavili in orisali značilnosti turistične atrakcije kot fenomena današnje sodobne družbe ter prispevali k razumevanju koncepta atrakcije na podlagi teorij in dejstev, ki so imele največji prispevek in vpliv na turistično misel. Za razumevanje koncepta atrakcije, kot ga poznamo in obravnavamo danes, smo pomembna izhodišča črpali iz kritičnih teorij turizma in Veblenove teorije brezdelnega razreda.

Po vzoru zagovornikov sistemskega pristopa $\mathrm{v}$ obravnavi turizma (Mill in Morrison,1985; Donald Getz, 1986; Richard McIntosh in Char- 
les Goeldner, 1986; Jafar Jafari, 1987; Neil Leiper, I990; Erick Laws, 1995 in drugi) smo turistično atrakcijo obravnavali kot sistem. To nam je omogočilo nadgradnjo razumevanja in delovanja modela sistema turistične atrakcije. V njem so podani različni vidiki doživljanja in zaznavanja kritičnih momentov v polju turistične atrakcije $s$ strani turistov, ki pa so lahko $\mathrm{v}$ veliko pomoč načrtovalcem in organizatorjem turističnih atrakcij, kakor tudi prispevek $\mathrm{k}$ teoretičnemu razumevanju koncepta sistema turistične atrakcije. Predvsem je v tem delu za namen načrtovanja in upravljanja turistične atrakcije pomemben vidik učinkovitega razumevanja.

$S$ pregledom zgodovinskega razvoja turističnih atrakcij in izpostavitvijo ključnih prelomnic $v$ tem razvoju smo izpostavili dva ključna skupna imenovalca vseh prelomnic $\mathrm{v}$ zgodovini turističnih atrakcij: to sta dostopnost in odnos družbe do prostega časa oz. turizma in atrakcij v ožjem pomenu. Dejstvo je, da se turistične atrakcije v sodobnem času razvijajo in oblikujejo na podlagi zaznanega vzorca. Dostopnost v fizičnem smislu pomeni možnost dostopa, obiska in doživetja atrakcije, $\mathrm{v}$ informacijskem smislu pa je dostopnost atrakcije ključna za njeno zaznavo s strani potencialnih obiskovalcev, v kolikor do njih prodre informacija o atrakciji in njenih značilnostih. Zato smo v tem delu opozorili na pomen promocijskih materialov, distribucijskih kanalov in načinov informiranja glede na nakupovalne navade sodobnega turista.

V delu, ko smo obravnavali načine razvrščanja turističnih atrakcij, smo na podlagi analize obstoječih znanih in značilnih tipologij atrakcij razbrali izrazit vzorec tipologije glede na različne vidike razvrščanja atrakcij. To je posledica večdimenzionalnosti in kompleksnosti turističnih atrakcij kakor tudi čedalje večjega obsega vrst turističnih atrakcij v sodobnem času. Ugotovljeno je bilo, da sta organizacijski in vsebinski vidik razvrščanja atrakcij pomembno izhodišče pri procesu odločanja, načrtovanja in upravljanja turističnih atrakcij in je zato potrebno skrbno in natančno razumevanje teh razlik.

Poglavje o turističnih vplivih in turističnih atrakcijah predstavlja izčrpen pregled turističnih vplivov v smislu njihovega opredeljevanja, razlogov za nastanek in osnovnih skupin (vrst) turističnih vplivov. Podane so strokovne razlage o značilnostih turističnih vplivov na podlagi nedavne in relevantne literature s tega področja. Med drugim je tozadevni prispevek viden $v$ poudarku, da je turistične vplive možno in nujno upravljati. Do te ugotovitve smo prišli s pomočjo povezovanja treh vidikov turističnega sistema s stopnjami organiziranosti in zavesti turističnega menedžmenta. Na ta način so predstavljeni trije možni pristopi v obravnavi oz. odzivanju menedžmenta na turistične vplive, ki pa so v turizmu 
neizogibni in sami po sebi dejstvo. Izpostavljeni so proaktivna vloga menedžmenta in načini obvladovanja ter upravljanja turističnih vplivov za dosego optimalnih rezultatov in učinkov v danih razmerah ter situacijah.

Sklepni dvi poglavji nadaljujeta razpravo o možnostih in priložnostih učinkovitega načrtovanja in upravljanja turističnih atrakcij skozi proces valorizacije turističnih atrakcij in obravnave atrakcije $\mathrm{v}$ luči turističnega proizvoda z vsemi njegovimi specifikami in značilnostmi. Poudarjeni so subjektivna narava turističnega doživetja in objektivne možnosti ter priložnosti menedžmenta in marketinga pri oblikovanju ter načrtovanju turističnih atrakcij na način, da se vpliva na tiste dejavnike zaznave pri obiskovalcih, ki omogočajo razvoj in ustvarjanje želenih turističnih doživetij in izkušenj. Zadovoljstvo obiskovalcev je zagotovo merilo uspeha v turizmu, sta pa tudi sprememba in inovacija dejstvo in merilo napredka terobstoja na turističnem trgu. Trendi v razvoju turističnih atrakcij naj bi se razvijali v smeri povezovanja in usklajevanja med akterji v sistemu atrakcij, kar je v skladu s pričakovanji sodobnih turistov in stopnjo zavesti ter organiziranosti v turističnem gospodarstvu. 



\section{Povzetek}

Turistične atrakcije so od nekdaj veljale in še danes predstavljajo glavno gonilno silo turizma ter turističnega razvoja, a hkrati, gledano $s$ sistemskega vidika, tvorijo osnovno enoto turizma in turistične dejavnosti. Zaradi atrakcije obiskovalci in turisti so - pridejo, obiščejo in doživijo atrakcijo, tako je ta osnovni motiv turističnega obiska in aktivnosti, kar kaže na njen izjemen ekonomski pa tudi družbeni in okoljski pomen. Pri tem ne gre pozabiti, da je sodobno turistično povpraševanje zelo heterogeno in $\mathrm{v}$ svojih pričakovanjih visoko zahtevno, kar narekuje zahtevo po dovršenosti, razvoju, inovacijah in nenehnem procesu nadgradnje kakovosti turističnih atrakcij. Poleg tega je zadovoljstvo s kakovostjo turistične izkušnje ob doživetju turistične atrakcije v neposredni povezavi z odnosom lokalne skupnosti do obiskovalcev in turizma kot tudi s kakovostjo sodelovanja in sinergijskih učinkov ob medsebojnem delovanju akterjev v turizmu. Slednje je prav gotovo v domeni menedžmenta turistične atrakcije, kompleksnost njegove naloge pa se odraža v konstantnem iskanju harmonije med interesi in videnji različnih skupin ter posameznih akterjev turističnega razvoja. Turistični uspeh ali konkurenčnost $\mathrm{v}$ turizmu pogosto povezujemo s sposobnostjo upravljanja turističnih atrakcij, ki od menedžmenta zahteva ne samo formalna znanja in spretnosti, pač pa čedalje subtilnejši posluh pri uravnavanju in uglaševanju posameznih enot $\mathrm{v}$ sistemu atrakcij v razmerju med ponudbo in povpraševanjem. Vsled tega je potrebno dodobra poznati temeljne prvine turističnih atrakcij, njihovih značilnosti, še posebej pa razumeti razlike med viri in privlačnostmi kot tudi sam proces valorizacije turističnih virov. $V$ tej knjigi gre za sistema- 
tično in analitično poglobljeno razpravo o fenomenu turistične atrakcije - od njenih vzvodov, korenin, anatomije in delovanja v prostoru in času.

Koncept turistične atrakcije je osvetljen skozi vidik družbenega konteksta in kritične teorije turizma, kakor tudi skozi prizmo t. i. brezdelnega razreda. $\mathrm{V}$ teoriji turizma so to izhodiščni parametri razumevanja družbene plati potrošnje in v povezavi s tem fenomena turistične potrošnje. Demokratizacija potovanj je po eni strani sprožila turizem zaradi dostopnosti (skozi nove transportne rešitve in spremembe $\mathrm{v}$ družbeni strukturi) in sočasno razvrednotila potovanje zaradi te iste dostopnosti (razslojenost družbe, razlike v kulturnem in socialnem kapitalu, vrednostnem sistemu, izobrazbi in vedenju), spričo katere turizem sodi v krog široke potrošnje, ne pa ekskluzivne izkušnje. $\mathrm{V}$ tem je njena paradoksalna dvojnost, blagoslov in prekletstvo. Demokratizacija potovanj je pospešila turistične tokove in turizem, kot ga poznamo danes, ga je pa zagotovo okradla vzvišenosti, avtentičnosti in njegove prvotne visoke estetske vrednosti. V trenutku, ko postane dostopno množici ljudi, potovanje postane turizem - turistično blago, ki ga lahko kupimo, prodamo, prilagodimo in materializiramo $\mathrm{v}$ dokaz in potrditev svojega lastnega družbenega statusa. To so poglavitni očitki kritične teorije turizma, nanašajoč se na njegovo množičnost. Po štirih desetletjih od nastanka trajnostnega koncepta razvoja turizma, ki je omogočil celovitejše dojemanje fenomena turizma in s tem njegovo postopno aplikacijo v turistično prakso, se kažejo spremembe $\mathrm{v}$ miselnosti in delovanju družbe vezano na koncept turistične atrakcije. S takim razvojnim zasukom v mentaliteti se krepi zavest odgovornosti v turizmu, kar polagoma, toda vztrajno spreminja njegovo nekoč splošno negativno konotacijo in ga postavlja ob bok bolj cenjenih in priznanih družbenih fenomenov. Sodobni čas nemara zaznamujejo družbene spremembe, ki omogočajo še večjo dostopnost turizma, posledično pa je paleta turističnih atrakcij vse bolj pestra in raznolika.

Učinkovitost upravljanja $\mathrm{v}$ turizmu kliče po razumevanju holistične strukture turistične atrakcije, kjer povezava treh ključnih elementov (turista, znamenitosti in zaznamovalca) predstavlja sklenjen krog in delujočo oz. vzpostavljeno turistično atrakcijo. Zdi se, da je osrednja os v tem sistemu zaznamovalec, ki daje informacijo o znamenitosti, s tem pa spodbudi interes in motivacijo turista, da to isto obišče in/ali doživi. Pomenu zaznamovalca, njegovim številnim in večplastnim funkcijam se v tej knjigi podrobno posvečamo, saj nas ta spoznanja peljejo k razumevanju odnosov v sistemu turistične atrakcije. Ne zgolj poznavanje elementov v strukturi sistema turistične atrakcije, marveč tudi njihova interakcija, povezave in odnosi ponujajo globlji in jasnejši vpogled v delovanje 
sistema, $s$ tem pa njegovo pristnejše razumevanje, kar ponuja instrumentarij za njegovo nadgradnjo, razvoj in napredek. Zatorej model sistema turistične atrakcije skozi faze potovalne izkušnje, ki ga v knjigi ilustriramo in izdatno opišemo, predstavlja koristno orodje za poglobljeno razumevanje in učinkovito upravljanje atrakcije na dolgoročni, trajnostni osnovi. Še več, razumevanje atrakcije skozi sistemsko strukturo omogoča poglobitev v vsebino njenih interakcij, procesov in povratnih informacij, $\mathrm{z}$ uporabo katerih menedžment $\mathrm{v}$ procesu odločanja lahko učinkoviteje načrtuje, kar je zanesljivo pot k trajnostni konkurenčnosti in uspehu na turističnem trgu.

$\mathrm{Z}$ zgodovinskim razvojem turističnih atrakcij v knjigi prispevamo ne samo pregled, marveč tudi poglobljeno diskusijo ob ključnih prelomnicah - trenutkih, ki so zaznamovali in usmerili razvoj turističnih atrakcij. Turizem in turistična aktivnost se tako postavljata v širši okvir fenomena prostega časa, kot dimenziji v življenju ljudi, ki predstavlja predpogoj zanj. Ugotavlja se, da je način življenja ljudi odločilno v korelaciji z načinom preživljanja prostega časa, kar lahko potrdimo tudi danes, in vse kaže, da je to edina oprijemljiva stalnica v preučevanju fenomena turizma. Znanstveno preučevanje prostega časa namreč osvetljuje vzgibe za turistično aktivnost in vedenje, čeprav je znanstveni korpus turistične teorije še v razvoju, saj je bila doslej pozornost bolj usmerjena k stroki turizma in ne toliko k temeljnim vprašanjem o turizmu kot družbenemu fenomenu. Enostransko preučevanje večplastnega in kompleksnega fenomena turizma je nezadostno in neučinkovito, kar rezultira $\mathrm{v}$ razdrobljeni teoriji, nepovezanih (včasih nasprotujočih si) konceptih in nenazadnje v nezmožnosti operacionalizacije in aplikacije nekaterih pomembnih spoznanj v praksi. Interdisciplinarni pristop pri preučevanju turizma se zdi docela ustrezen način, saj omogoča povezovanje in dopolnjevanje dognanj različnih disciplin, obvladovanje večplastnosti pri obravnavi problematike, skratka celovitejši pogled. V knjigi se opiramo na kontekstualno obravnavo vzrokov in posledic dogodkov, ki so oblikovali značilnosti turističnih atrakcij, in skozi zgodovinske spremembe ugotavljamo dve pomembni konstanti: pomen, ki ga turističnim atrakcijam pripisuje družba, in dostopnost turističnih atrakcij v smislu razpoložljivosti prostega časa, sredstev in interesa zanje.

Pri razvrščanju atrakcij gremo korak naprej od ozkega pregleda obstoječih aktualnih klasifikacij, saj so raziskave številnih avtorjev s tega področja nakazale korelacijo med načinom razvrščanja turističnih atrakcij in učinkovitostjo njihovega upravljanja in organizacije. Različni pristopi pri razvrščanju turističnih atrakcij namreč vplivajo in narekujejo raz- 
lične pristope pri njihovem načrtovanju, vodenju in upravljanju. Tako je razvrščanje atrakcij po poreklu turističnega vira zgolj orientacijsko in informativno, saj brez upoštevanja drugih ključnih dejavnikov, značilnosti in vsebine atrakcij ne omogoča zadostno osnovo za primerno ravnanje, valorizacijo in dolgoročno konkurenčnost atrakcije na turističnem trgu. V knjigi se podrobneje posvečamo razvrščanju atrakcij glede na prostorsko organizacijo, saj prostorske lastnosti v večji meri določajo posledice obiska in vedenja turistov, pogoje za trženje atrakcije in omejitve pri načrtovanju in upravljanju atrakcije. Nenazadnje izpostavljamo tudi pomen t. i. čezmejnih ali perifernih turističnih atrakcij, ki v zadnjih dveh desetletjih zaradi svoje neprimerljive drugačnosti predstavljajo zanimivo turistično perspektivno in specifično področje, s čimer vzbujajo interes številnih obiskovalcev. Velikemu številu pristopov pri razvrščanju turističnih atrakcij botruje dejstvo, da so družbene spremembe in spremenjeni vzorci preživljanja prostega časa ljudi privedli do izjemnega porasta raznovrstnosti atrakcij.

Turističnim vplivom v knjigi namenjamo posebno pozornost zaradi njihove ključne vloge pri načrtovanju turizma in razvoju turističnih atrakcij. Ugotavljamo namreč, da turistične atrakcije brez turističnih vplivov niso mogoče, prav tako pa natančneje razložimo pomembno ugotovitev, na žalost premalo upoštevano in aplicirano v praksi, da je turistične vire ne samo možno, ampak predvsem nujno potrebno upravljati. Turistični vplivi kot skupek sprememb, ki se kažejo v nekem prostoru, so posledica vsake turistične aktivnosti, nastanejo pa na podlagi interakcij, značilnih za turizem ( $v$ razmerju med turisti, domačini, turistično destinacijo oz. atrakcijo), in pa zaradi neusklajenosti med ponudbo in povpraševanjem v turizmu. Velja namreč trdno prepričanje, da so turistične dobrine omejene, medtem ko je turistično povpraševanje po njih zmeraj večje. Prostor je v kontekstu turističnih vplivov temeljni okvir, saj iz njega izhajajo sestavine (inputi) za turistično aktivnost in v njega prehajajo rezultati te iste turistične aktivnosti (outputi). Oba ta momenta sta ključna za konkurenčnost in trajnostno učinkovitost turistične atrakcije ter $\mathrm{v}$ veliki meri odražata uspešnost turističnega menedžmenta, ki atrakcijo upravlja. Poleg izčrpnega pregleda vrst turističnih vplivov se natančneje posvečamo njihovim značilnostim, ki v osnovi predstavljajo nujen predpogoj za učinkovito upravljanje $\mathrm{v}$ turizmu. Iz specifičnih značilnosti turističnih vplivov namreč izhajajo zakonitosti njihovega delovanja. Razumevanje turističnih vplivov pa menedžmentu omogoča njihovo učinkovitejše načrtovanje, pri čemer gre za tak proces odločanja, $v$ katerem se uporabljajo povratne informacije, ki so rezultat procesov in interakcij $\mathrm{v}$ sistemu turi- 
stične atrakcije. Na podlagi treh vidikov turističnega sistema, ki izhajajo iz sistemske teorije in načinov odziva menedžmenta na turistične vplive, generiramo in podrobno predstavimo tri možne načine obravnave turističnih vplivov. Ker gre za različne stopnje organiziranosti v turističnem sistemu, sklepamo, da gre za faze odziva na turistične vplive, ki omogočajo različne stopnje učinkovitosti pri njihovem upravljanju. V tem delu namreč tri stopnje organiziranosti sistema turistične atrakcije povežemo $s$ tremi vidiki turističnega sistema.

Središčno pozornost pri obravnavi upravljanja turističnih atrakcij namenjamo valorizaciji turističnih virov, ko po fazah podrobno prikažemo delovanje in aktivnosti menedžmenta za to, da se iz turističnega vira ustvari turistično atrakcijo. Ta del knjige integrira vsa pomembna teoretična in praktična dognanja s področja obravnavane teme. Gre za temeljne predpostavke, da turistični vir ne predstavlja turističnega uspeha per $s e$, temveč je to turistični potencial ali komparativna prednost, vse dokler se z njim ne začne upravljati. Na tem mestu se ponovno poudari pomen in nuja razumevanja upravljavskega vidika menedžmenta turističnih atrakcij, ki je v praksi čestokrat prezrt in pomanjkljivo razumljen. Brez ustreznega upravljanja turistični vir ne dosega dodane vrednosti, ki je osnova za njegovo tržno pozicioniranje kot tudi za diferenciacijo na turističnem trgu, saj ga ravno njegova dodana vrednost loči od atrakcije in je pogoj za njegov nastanek. $V$ tem delu turistično atrakcijo obravnavamo kot turistični proizvod $\mathrm{z}$ vidika turistične ponudbe pa tudi kot turistično izkušnjo z vidika turističnega povpraševanja. Oba vidika sta pomembna v vseh fazah procesa valorizacije turističnega vira (načrtovanje, razvoj, trženje) zaradi filigranske specifike turizma, zaradi česar ju je potrebno razumeti v medsebojni povezavi. Zaradi visoke kompleksnosti turističnega proizvoda in izkušnje ter prevladujočega deleža nematerialnosti pri obeh konceptih (odnosi, občutki, vzdušje, doživetja, zaznave) je poudarek na spodbujanja zavedanja, da je turistična izkušnja atrakcije izključno v domeni obiskovalca, temelji pa na proizvodu. Kreiranje turističnega pro izvoda je tako učinkovitejše, ko obiskovalca natančno poznamo, s čimer lahko vplivamo na njegovo turistično doživetje.

Pomen prostega časa v sodobni družbi spodbuja krepitev etike in estetike prostega časa, prav tako pa dostopnost sredstev, časa in informacij vpliva na naraščanje raznovrstnosti in številnosti turističnih atrakcij. Vsa področja življenja v sodobni družbi so zaznamovana s sunkovitimi tehnološkimi, gospodarskimi in splošnimi družbenimi spremembami, kar se nazorno zrcali v turističnih trendih in vedenju obiskovalcev. Spremembe v pričakovanjih in vedenju obiskovalcev na vsak način odločno terjajo 
učečo se organizacijo, čustveno senzibilno in prožno, operativno vitalno ponudbo turističnih atrakcij v vrhunski kondiciji, ki bo zmeraj dva koraka pred povpraševanjem in svojimi tekmeci. Razumevanje vrednostnega sistema obiskovalca, njegovih želja in potreb od ponudnika turističnih atrakcij zahteva visoko mero empatije in čustvene inteligence, saj bodo $v$ prihodnje ravno ta področja priložnost za dosego diferenciacije, učinkovitega upravljanja in trajnostne konkurenčnosti na turističnem trgu. V ospredje prihaja vse bolj poglobljen interes in odnos obiskovalcev, krepi se izobraževalni namen turističnega obiska, doživljajska dimenzija z vključitvijo vseh čutov, pri čemer sodobna tehnologija igra zelo pomembno vlogo. Predvideva se razvoj turizma v smeri turističnih atrakcij, ki ponujajo visoko kakovostna, celostna doživetja in kontemplacijo, vse manj pa bo menda takšnih atrakcij, ki za obiskovalca predstavljajo pasivno udeležbo, materialno konzumacijo in netrajnostno potrošnjo. Raven zavedanja $\mathrm{v}$ vedenju obiskovalcev narekuje vse bolj sofisticirano vedenje turistične ponudbe, kar v ospredje postavlja naravo, zdravje, pristnost in odgovornost na vseh področjih delovanja. Te temeljne vrednote prispevajo $\mathrm{k}$ spodbujanju ustvarjalnosti in inovacij v turizmu na različnih področjih, toda vedno v korist in dobrobit širših ciljev družbenega in naravnega okolja. Kakovost življenja v veliki meri vpliva na kakovost preživljanja prostega časa, po drugi strani pa se krepi zavedanje o pomenu sodelovanja, povezovanja in partnerstev v turizmu, zato so tu napovedi prihodnjega razvoja v smeri večjega angažiranja lokalnih skupnosti in povezav med turističnimi akterji. Vse bolj bo prepoznana vrednost sodelovanja $\mathrm{v}$ turizmu zaradi zavedanja o njegovi večplastni povezanosti z drugimi dejavnostmi in področji ter skupnih koristi in prednosti takega delovanja. 


\section{Summary}

Visitor attractions have been consistent through the time and they still represent the driving force of tourism and tourism development but at the same time, from the systemic point of view, they form a primary unit of tourism and tourist activity. The tourists exist because of the visitor attractions - they come, visit and experience the attraction; therefore it is the main motive of a tourist visit and his activities, which is indicating its immense economic, social and environmental influence. At this point one has to bear in mind that contemporary tourism demand is highly heterogeneous and challenging in its expectations requiring from the tourism planners to be highly sophisticated, striving for progress and innovation, as well as for continuous process of quality enhancement of visitor attractions. Furthermore, the visitor satisfaction with the quality of visitor attraction is in direct correlation not only with the residents' attitude towards the visitors and the tourism, but also with the collaboration quality and synergistic effects of tourism stakeholders' interactions. The latter is the core task of the visitor attraction management where the complexity of their efforts shows in constant endeavour to harmonise and tune the different interests and visions of tourism stakeholders. Success in tourism or the tourism competitiveness relates to the competence of managing the visitor attractions, not only as a part of the management formal knowledge and skills, but inevitably more and more as their subtle ear in coordination and tuning of partial units of visitor attractions system. That is the reason why it is urgent to be aware of the basic components of visitor attractions, their characteristics, especially to understand the differences between tourism resources and attractions, and valorisa- 
tion of tourism resources. In this book, we systematically and analytically discuss the visitor attraction phenomenon, their levers, roots, anatomy and functioning in the space and time.

The intention was to shed some light at the concept of visitor attraction through the social context and critical theory of tourism as well as through the prism of so-called leisure class theory. These are the standpoint parameters to comprehend the social side of consumption in relation to tourism consumption phenomenon. Democratisation of travel triggered the tourism development due to the accessibility (through the new transportation options and social structure changes) but simultaneously it devaluated travel due to the same accessibility (social stratification, differences in cultural and social capital, value system, education and behaviour), corollary of which tourism was not an exclusive experience any more, but rather a consumer good. In this lies its paradoxical duality, its blessing and curse.

Democratisation of travel has accelerated the tourism development as we perceive it today; nevertheless, it has defraud it of sublimity, authenticity and its former high aesthetic value. When travel becomes accessible to the people it becomes the tourism - a consumption good, which one can buy, sell, adjust and materialise for the purpose of evidence and verification of his own social status.

These are the main reprimands of the critical theory of tourism considering its massiveness. After the four decades of sustainable tourism concept appearance, which has enabled more holistic perception of tourism phenomenon, and at the same time its gradual application in the practice, the changes of the mind-set and the functioning of society considering the concept of visitor attractions have appeared. That developmental shift of the mind-set reinforces the awareness of responsibility in tourism, which gradually but persistently changes the previously negative connotation of tourism and it places it alongside other acknowledged phenomena of the society. The modern era may be marked with social changes, which enable even better accessibility of tourism, but consequently the number and variety of visitor attractions arise.

Efficiency of tourism management urges on understanding the holistic structure of visitor attraction where the connection between the key elements (tourist, sight and marker) represents the establishment and enables functioning of the visitor attraction. It seems that the marker represents the principal axis in this system, which provides the information about the attraction and thereby incites the motivation for a visit or experience. In this book we deepen the discussion about the meaning of 
the marker, its numerous and multifaceted functions, because the understanding of its operation ensures a powerful insight in the relationships within the visitor attraction. Recognising the elements of the system is insufficient; their interactions, interconnections and relationships reveal much more sophisticated, intelligible insights of the system functioning, consequently yielding the management with a plethora of instruments for the system upgrade, evolvement and advancement. Therefore, the model of visitor attraction system through the travel phases illustrated and described in the book, represents a very useful tool for efficient and sustainable management of visitor attractions. Even more, comprehension of visitor attraction through its system structure empowers immersion into the fabric of interactions, processes and feedback, which assist management in decision-making process to be highly efficient in planning enabling the sustainable competitiveness and success on the tourism market.

A historical overview of tourism attractions development provides not only an overview but also a deepened interpretation of the milestones in tourism, which have marked and directed its course. We place tourism and tourist activity into the wider frame of the leisure phenomenon as a dimension of life, establishing a precondition for it. We note the decisive correlation between the way of life and the way of leisure, which is also current in the present time, and which seems to be the single tangible factor in the tourism phenomenon investigation. Scientific research of leisure disclose impulses for the tourist behaviour and activity, although the tourism theory corpus is still developing due to a primary attention on the practice of tourism instead on its fundamental questions. One-sided investigation of such a complex and multifaceted phenomenon is detrimentally deficient, which reflects in fragmented theory, unrelated (sometimes contradicting) concepts, and finally in inability of operationalization and application of some important cognitions in the practice. An interdisciplinary approach in investigation of tourism seems to be appropriate, because it enables knowledge integration and complementation of different disciplines helping to comprehend and manage such a multi-layered issue. In the book we base our research on the contextual understanding of the causes and effects of events that have shaped features of visitor attractions and thus define the two main constant factors through the history of visitor attractions, namely the meaning that is attributed to visitor attractions by the society and the accessibility of visitor attractions in the sense of leisure availability, means and interest.

In sorting visitor attractions we go a step further from barely an overview of existing current classifications due to the latest findings of signif- 
icant correlations between attractions classification and their organisational and management efficiency. Different approaches in classification of visitor attractions actually influence and condition the approaches of their planning and management. Therefore, the classification of visitor attractions according to the origin of tourism resources gives purely information and orientation, because without other key factors, attributes and content of the attraction, the base for efficient valorisation and competitive sustainability management of the attraction system is insufficient. In this book we closely discuss the classification of visitor attractions considering the spatial organisation, because spatial features mainly determine the consequences and behaviour of tourist visit, marketing conditions and restrictions of planning and managing the visitor attraction. Last but not least, we highlight the importance of so-called cross-border attractions or peripheral attractions that have lately shown their huge tourist potential because of their unique and incomparable appeal attracting a large number of visitors. The multitude of approaches in classification of visitor attractions is corollary of social changes and modified leisure patterns that have led to enormous growth of heterogeneity due to changed patterns of leisure.

Significant attention is dedicated to tourism impacts due to their essential role in planning and developing the visitor attractions. We deduce that visitor attractions are not possible without tourism impacts. We also point to the fact, which is too often overlooked and neglected by tourism practitioners, that the tourism impacts not only can but ought to be managed. Tourism impacts, as a set of changes in a certain location, represent a sum of tourism activity consequences as an output of interactions characterising tourism (between locals, tourists and destination or attraction) and the imbalances between tourism supply and demand. Indeed, there is a firm belief that tourism resources are limited; nonetheless, demand for them has been constantly rising. Basic framework in the context of tourism impacts represents the space owing to the fact that tourism resources arise from the space and the consequences of tourism activities are evident in that same space. Both aspects of the spatial issues are essential for the sustainable competitiveness largely reflecting the efficiency of visitor attraction management. In addition to a comprehensive overview of the variety of tourism impacts, the book focuses more specifically on their characteristics, which in essence constitute a prerequisite for their effective management. Specific characteristics of the tourism impacts determine their operationalization revealing a thorough insight into their comprehending. Tourism impacts understanding enables more effective 
and efficient planning for the management, where in a decision-making process they use feedback as the results from processes and interactions in the tourist attractions system. Based on the three aspects of tourism system following the system theory and the ways of management responses to the tourism impacts, we generate and comprehensively introduce the three possible ways of dealing with tourism impacts. Regarding the different developmental phases of organisation in tourism system, we assume that the response refers to those phases resulting in different efficiency of their management. At this point, the three aspects of tourism system attractions are associated with the three developmental phases of tourism system.

In dealing with the visitor attractions management, we dedicate central attention to the process of tourism resources valorisation describing in details each step in order to get the visitor attraction out of the tourism resource. This specific part of the book integrates the entire important theoretical and practical knowledge considering the research topic. A presumption is that no attraction is an attraction per se, as long as it is not managed. Indeed, it represents barely a tourist potential or a comparative advantage. We emphasise the importance of considering the managerial aspects of visitor attractions, which tourism practitioners often overlook and/or inadequately comprehend. Accordingly, without the appropriate management, the visitor attraction may not attain the added value, which is the foundation for its market positioning and differentiation. The added value actually distincts the tourism resource from the visitor attraction and represents an essential prerequisite for it. Visitor attraction is comprehended as a tourism product from the tourist offering aspect and as an experience from the tourist demand aspect. Both aspects are crucially important in each phase of the valorisation process (planning, development, and marketing) due to the filigree specifics of tourism, which makes an urgent need to consider them interconnected. Because of the high complexity of the tourism product and experience as well as their predominant characteristics of intangibility (relationships, feelings, atmosphere, experiences, perceptions) the emphasis is on strengthening the awareness that the experience itself is the exclusive domain of the visitor, but it certainly derives from the tourist product. The creation of tourist product is much easier and efficient when we know the visitors very well, which gives us an ability to influence their experience.

The meaning of leisure in modern society enhance its ethic and aesthetic value as well as accessibility of finance, time and information amplifying an increase of variety and number of visitor attractions. All as- 
pects of modern life are designated by tectonic changes of technology, economy and society, which is clearly reflected on the tourism trends and visitor behaviour. Visitor expectations and behaviour changes require learning organisation, emotionally sensitive and flexible mind-set, operatively vibrant offerings of superb attractions, always two steps ahead of their competitors and the market. The understanding of visitor value system and expectations requires from the tourism planners immense capacity of empathy and emotional intelligence, which in nearer future will represent the main areas of differentiation and competent management for achieving sustainable competitiveness on the market. Ever-deepening interest and attitude of visitors, educational motive and multisensory experience become evident trends largely followed and supported by modern technology. We anticipate the development of attractions that offer exquisite quality, integrated experiences and contemplation, and on the other hand, fewer of such attractions that enable passive participation, physical and unsustainable consumption for visitors. The level of awareness and behaviour of visitors dictates the increasingly sophisticated response of management, which puts in the forefront the nature, health, authenticity and responsibility in all areas of activities. These core values contribute to the promotion of innovation in various fields, but always for the benefit of broader social goals. The quality of life has a great impact on the quality of leisure, on the other hand, awareness of cooperation importance, networking and partnerships in tourism is strengthened; therefore, the forecasts for future development are towards greater engagement of local communities and interrelationships between stakeholders. The value of collaboration in tourism will increase due to the growing awareness of its multifaceted connection with other activities and areas, and its common benefits and advantages. 


\section{Literatura in viri}

Archer, B., Cooper, C. in Ruhanen, L. (2005). The positive and negative impacts of tourism. V W. F. Theobald (ur.), Global Tourism, Third edition (str. 79-102). Maryland Heights, MO: Elsevier Butterworth-Heinemann.

Austin, N. K. (2002). Managing heritage attractions: Marketing chalenges at historical sensitive sites. International Journal of Tourism Research, 4(6), 447-457.

Babbie, E. (1995). The practice of social research, 7 th edition. Belmont, CA: Wadsworth Publishing Company.

Beerli, A., in Martin, J. D. 2004. Factors influencing destination image. Annals of Tourism Research, 3I(3), 657-68I.

Benckendorff, P. J. (2006). Attractions megatrends. V D. Buhalis in C. Costa (ur.), Tourism business frontiers: Consumers, products and industry (str. 200-210). Oxford: Elsevier.

Benckendorff, P. J., in Pearce, P. L. (2003). Australian tourist attractions: The Link between organizational characteristics and planning. Journal of Travel Research, 42(I), 24-35.

Boorstin, D. J. (1964). The image: A guide to pseudo-events in America. New York, NY: Harper.

Boorstin, D. J. (2012). The image: A guide to pseudo-events in America. New York, NY: Vintage.

Botti, L., Peypoch, N., in Solonandrasana, B. (2008). Time and tourism attraction. Tourism Management, 29(3), 594-596. 
Bourdieu, P. (2010/1986). The forms of capital. V I. Szeman in T. Kaposy (ur.), Cultural theory: An anthology (str. 8I-93). Malden, MA: Wiley-Blackwell.

Bramham, P., in Wagg, S. (2014) An introduction to leisure studies: Principle and practice. London: SAGE.

Brezovec, A., Sedmak, G., in Vodeb, K. (2007). Srce Istre: Kulturna dediščina skozi oči turistične javnosti, Koper: Založba Annales, Zgodovinsko društvo za Južno Primorsko.

Brunt, P., in Courtney, P. (1999). Host perception of socio-cultural impacts. Annals of Tourism Research, 26(3), 493-515.

Buhalis, D., in Costa, C. (2006). Tourism management dynamics: Trends, management and tools. Oxford: Butterworth-Heinemann.

Bulc, G. (2004). Proizvodnja kulture: vloga in pomen kulturnih posrednikov. Maribor: Subkulturni azil.

Chase, L. C., Amsden, B., in Phillips, R. G. (2012). Stakeholder engagement in tourism planning and development. V M. Uysal, R. Perdue in J. Sirgy (ur.), Handbook of tourism and quality-of-life (str. 475-490). Dordrecht: Springer.

Coccossis, H., in Constantoglou, M. E. (2008). The use of typologies in tourism planning: Problems and conflicts. V H. Coccossis in Y. Psycharis (ur.), Regional analysis and policy: The Greek experience. (273-295). Heidelberg: Physica Verlag.

Cooper, C., Fletcher, J., Gilbert, D., in Wanhill, S. (1993). An introduction to tourism. V J. Fletcher, A. Fyall, D. Gilbert in S. Wanhill Tourism: Principles and practice, 7-I2. London: Pitman Publishing.

Čomić, Đ., in Kalmić, L. (2007). Analiza multifaznih turističkih doživljaja. Turizam, Savremene tendencije u turizmu, hotelijerstvu i gastronomiji, $11,7-9$.

Dann, G. (2000). i 8 theoretical advances in the sociological treatment of tourism. V S. R. Quah in A. Sales (ur.), International handbook of sociology (str. 367-384). London: Sage.

Deery, M., Jago, L., in Fredline, L. (2012). Rethinking social impacts of tourism research: A new research agenda. Tourism Management, 33(I), 64-73.

Diedrich, A., in García-Buades, E. (2009). Local perceptions of tourism as indicators of destination decline. Tourism Management, 3o(4), 5 I 2-52 I.

Doxey, G. V. (1975). A causation theory of visitor resident irritants: Methodology and research inference. V Sixth annual conference research asso- 
ciation proceedings of the Travel Research Association (str. 195-198). San Diego, CA.

Fyall, A., Leask, A., in Garrod, B. (2002). Introduction: Visitor attractions. The International Journal of Tourism Research, 4(5), 333-335.

Fyall, A., Garrod, B., Leask, A., in Wanhill, S. (2008). Managing visitor attractions. London: Routledge.

Getz, D. (1986). Models in tourism planning: Towards integration of theory and practice. Tourism Management, 7(I), 2 I-32.

Ghemawat, P. (1991). Commitment. The dynamic of strategy. New York, NY: The Free Press.

Gunn, C. A. (1988). Vacationscape: Designing tourist regions. New York, NY: Van Nostrand Reinhold.

Gunn, C. A. (1997). Vacationscape: Developing tourist areas, 3 rd edition, Washington, DC: Taylor and Francis.

Gunn, C. A., in Var, T. (2002). Tourism planning: Basics, concepts and cases. London: Routledge.

Harris, R., in Howard, J. (1996). Dictionary of travel, tourism and hospitality terms. Melbourne: Hospitality Press.

Holden, A. (2004). Tourism studies and the socialsciences. London: Routledge.

Holloway, J. C. (1994). The business of tourism, 4th ed. London: Pitman Publishing.

Howie, F. (2003). Managing the tourist destination. London: YHT Ltd.

Hunt, S. D. (2000). A general theory of competition, resources, competeences, productivity, economic growth (Marketing for a new century). Thousands Oaks, CA: Sage Publications.

Inskeep, E. (1991). Tourism planning: An integrated and sustainable development approach. Nw York, NY: Van Nostrand Reinhold.

Jafari, J. (1987). Tourism models: The sociocultural aspects. Tourism Management, 8(2), I5I-I59.

Jeffries, D. J. (197I). Defining the tourist product - And its importance in tourism marketing. The Tourist Review, 26(I), 2-5.

Johns, N., in Hoseason, J. (200I)."Which way for heritage visitor attractions?” V S. Drummond in I. Yeoman (ur.), Quality issues in heritage visitor attractions (str. 222-242). Oxford: Butterworth-Heinemann.

Jurinčič, I. (2005). Carrying capacity assessment of Slovene Istria for tourism. V A. Kungolos, C. A. Brebbia in E. Beriatos (ur.), Sustainable de- 
velopment and planning II. (str. 725-733). Southampton; Boston, MA: WIT Press.

Krašna, T. (2007). Trženje v turizmu (Vaje: študijsko gradivo za interno uporabo). Bled: Višja strokovna šola za gostinstvo in turizem Bled.

Kretzschmar, A. (2009). Attractions and destination management (Course material). Stralsund: University of Applied Sciences Stralsund.

Kruczek, Z. (201 I). Current trends in the development of tourist attractions. Pridobljeno s http://www.proksenia.pl/download/Current_Trends_in_The_Development_of_Tourist_\%2oAttractions.pdf

Kruczek, Z. (2015). Analysis of visitor attendance at Polish tourism attractions. Turyzm, 25(I), 47-56.

Kušen, E. (2000). Skrb za turističku atrakcijsku osnovu: postojeće stanje i metodološki okvir. Turizam, 48(3), 313-334.

Kušen, E. (2002). Tourism attraction base. Zagreb: Institut za turizam.

Kušen, E. (2010). A system of tourism attractions. Tourism: An International Interdisciplinary Journal, 58(4), 409-425.

Laws, E. (1995). Tourism destination management issues, analysis and policies. London: Routledge.

Leask, A. (2008). The nature and role of visitor attractions. V A. Fyall, A. Leask, B. Garrod in S. Wanhill, Managing visitor attractions (str. 3-15). London: Routledge.

Leask, A. (2010). Progress in visitor attraction research: Towards more effective management. Tourism management, 3I(2), I55-I66.

Leiper, N. (1990). Tourist attraction systems. Annals of Tourism Research, $17(3), 367-384$.

Lew, A. A. (1987). A framework of tourist attraction research. Annals of Tourism Research, I4(4), 553-575.

Lomine, L., in Edmunds, J. (2007). Key concepts in tourism. Basingstoke, Hampshire; New York, NY: Palgrave Macmillan.

MacCannell, D. (1976). The tourist: A new theory of the leisure class. Berkeley, CA: University of California Press.

Magaš, D. (1997). Turistička destinacija. Opatija: Hotelijerski fakultet Opatija.

Mason, P. (2015). Tourism impacts, planning and management. London: Routledge.

Mathieson, A., in Wall, G. (1996). Tourism: Economic, physical and social impacts. Harlow: Longman. 
McIntosh, R. W., in Goeldner, C. R. (1986). Tourism: Principles, practices, philosophies, sth edition. New York, NY: Wiley.

McKercher, B., in du Cros, H. (2002). Cultural tourism: The partnership between tourism and cultural heritage management. New York, NY: Haworth Hospitality Press.

Middleton, V. T. C. (1988). Marketing in travel and tourism. Oxford: Heinemann.

Middleton, V. T. C., Fyall, A., Morgan, M., in Ranchhod, A. (2009). Marketing in travel and tourism. London: Routledge.

Mihalič, T. (2002). Konkurenčnost slovenskega turističnega gospodarstva. Pridobljeno s http://www.sigov.si/zmar/sgrs/diskusij/turizem.html

Mill, R. C., in Morrison, A. M. (1985). The tourism system: An introductory. Engelwood Cliffs, NJ: Prentice Hall.

Mill, R. C., in Morrison, A. M. (2002). The tourism system. Dubuque, IA: Kendall Hunt Publishing.

Nunkoo, R., Ramkissoon, H., Gursoy, D., in Chi, C. (2009). A Model for understanding residents' support for tourism in small islands. Prispevek na konferenci Hospitality and Tourism Management ICHRIE Annual Conference, San Francisco, 29. julij-I. avgust.

Olsen, M. D., Ching-Yick Tse, E., in West, J. J. (1992). Strategic management in the hospitality industry. New York, NY: ITP.

Page, S., in Connell, J. (2006). Tourism: A modern synthesis. Endover, MN: Cengage Learning EMEA.

Pearce, P. L. (1991). Analysing tourist attractions. The Journal of Tourism Studies, 2(I), 46-55.

Perez, E. A., in Nadal, J. R. (2005). Host community perceptions: A cluster analysis. Annals of Tourism Research, 32(4), 925-94I.

Pizam, A., Uriely, N., in Reichel, A. (2000). The intensity of tourist-host social relationship and its effects on satisfaction and change of attitudes: The case of working tourist in Israel. Tourism Management, 2I (4), 395-406.

Poon, A. (1993). Tourism, technology and competitive strategies. Wallingford: CAB International.

Poria, Y., Reichel, A., in Brian, A. (2006). Heritage site management - Motivations and expectations. Annals of Tourism Research, 33(I), I62-178.

Porter, E. M. (1994). Toward a dynamic theory of strategy. V Rumelt, R. P., Schnedel, D. E., in Teece, D. J. (ur.), Fundamental issues in stretegy: 
A research agenda (str. 423-462). Boston, MA: Howard Business Scholl Press.

Porter, E. M. (1998). The competitive advantage of nations. London: Macmillan Press LTD.

Prašnikar, J., in Debeljak, Ž. (1998). Ekonomski modeli za poslovno odločanje. Ljubljana: Gospodarski vestnik.

Pronovost, G. (2000). The collapse of the leisure society? New challenges for the sociology of leisure. V S. R. Quah in A. Sales (ur.), International handbook of sociology (str. 355-356). London: Sage.

Richards, G. (2002). Tourism attraction systems: Exploring cultural behavior. Annals of Tourism Research, 29(4), 1048-1064.

Ritchie, J. R. B., in Crouch, G. I. (1993). Comopetitiveness of international tourism - A framework for understanding and analysis, V Competitiveness of long hould destination. St. Gallen: AIEST.

Ritchie, J. R. B., in Crouch, G. I. (2003). The competitive destination: A sustainable tourism perspective. NewYork, NY: Cabi.

Ritchie, J. R. B., in Zins, M. (1978). Culture as determinant of the attractiveness of a tourism region. Annals of Tourism Research, 5(2), 252-267.

Scarles, C. (2010). Where words fail, visuals ignite: Opportunities for visual autoethnography in tourism research. Annals of Tourism Research, 37(4), 905-926.

Shani, A., in Pizam, A. (2012). Community participation in tourism planning and development. V M. Uysal, R. Perdue in J. Sirgy (ur.), Handbook of tourism and quality-of-life (str. 547-564). Dordrecht: Springer.

Sharpley, R. (1999). Tourism, tourists and society, 2nd edition. Huntingdon: Elm Publications.

Sharpley, R. (2009). Tourism development and the environment: Beyond the sustainability? New York, NY: Earthscan.

Smale, W. (2006). Eden Project's regeneration work. Pridobljeno s http:// news.bbc.co.uk/ I/hi/business/5216102.stm

Sotiriadis, M., in Loedolff, C. (2015). Nature-based visitor attractions and alliances/partnerships: Suggesting a collaboration framework and the factors determining effectiveness. Journal of Human Ecology, 49(I-2), 89-IOI.

Swarbrooke, J. (1999). Sustainable tourism management. New York, NY: Cabi.

Swarbrooke, J. (200I). Key challenges for visitor attraction managers in the UK. Journal of Retail \& Leisure Property, I (4), 318-336. 
Swarbrooke, J. (2002). Development and management of visitor attractions, 2nd edition. Washington, DC: Taylor and Francis.

Šturm, P., in Ruzzier, M. (2010). Turistične znamenitosti. Koper: Društvo za akademske in aplikativne raziskave.

Tajnikar, M. (2000). Slovenski turizem na poti v Evropsko unijo. V M. Tekavčič (ur.), Slovenski turizem in naše vključevanje v evropske integracije, strokovni posvet, Maribor, Iggg (str. I I-20). Portorož: Turistica, Visoka šola za turizem, Portorož.

Timothy, D. J., in Boyd, S. W. (2006). Heritage tourism in the 2 Ist century: Valued traditions and new perspectives. Journal of Heritage Touri$s m, I(\mathrm{I}), \mathrm{I}-\mathrm{I} 6$.

Turner, L., in Ash, J. (1975). The golden hordes. London: Constable.

Urry, J. (2005). The tourist gaze. Newburry Park, CA: SAGE Publications.

Veblen, T. (2009). The theory of the leisure class. Oxford: Oxford University Press.

Vodeb, K. (2014). Turistična destinacija: sodobna obravnava koncepta. Koper: Založba Univerze na Primorskem.

Wall, G. (1997). Sustainable tourism - Unsustainable development. V J. J. Pigram in S. Wahab (ur.), Tourism, development and growth: The challenge of sustainability (str. 33-49). London: Routledge.

Walsh-Heron, J., in Stevens, T. (1990). The management of visitor attractions and events. Upper Saddle River, NJ: Prentice Hall.

Wang, Y., Pfister, R. E., in Morais, D. B. (2006). Residences attitude toward tourism development: A case study of Washington, NC. V R. Burns in K. Robinson (ur.), Proceedings of the 2006 Northeastern Recreation Research Symposium (str. 4I I-4I9) Newtown Square, PA: U. S. Department of Agriculture, Forest Service, Northern Research Station.

Wanhill, S. (1997). Peripheral area tourism: A European perspective. Progress in Tourism and Hospitality Research, 3(I), 47-70.

Watson, S., in McCracken, M. (2002). No attraction in strategic thinking: Perceptions on current and future skills needs for visitor attraction managers. International Journal of Tourism Research, 4(5), 367-378.

Weidenfeld, A., Williams, A. M., in Butler, R. W. (2010). Knowledge transfer and innovation among attractions. Annals Of Tourism Research, $37(3), 604-626$.

Weiermair, K., in Peters, M. (2000). Tourist attractions and attracted tourists: how to satisfy today's' fickle'tourist clientele? Journal of Tourism Studies, $I I(\mathrm{I}), 22-29$. 
Turistične atrakcije

Wilkinson, P. (200I). Tourism development in Anguilla. Tourism Recreation Research, 26(3), 33-41.

Williams, S. (1998). Tourism geography. London: Rutledge.

Yale, P. (1991). From tourist attractions to heritage tourism. Huntingdon: ELM publications.

Zorko, D. (I999). Uvod v turizem. Ljubljana: Zavod Republike Slovenije za šolstvo. 


\section{Imensko kazalo}

A

Amsden, B. 90

Archer, C. 86

Ash, J. 94

Austin, N. K. 20, 64

B

Babbie, E. 52

Beerli, A. $\mathbf{1 8}$

Benckendorff, P. J. 20, 1 IO

Boorstin, D. J. 23, 25, 26, 27, 28, 29, 30, 94

Botti, L. 34

Bourdieu, P. 30

Boyd, S. W. 20

Bramham, P. 26,58

Brezovec, A. IoI

Brian, A. 20

Brunt, P. 89

Buhalis, D. 108

Bulc, G. 30

Butler, R.M. I2

C

Chase, L. C. 90, 9I

Chi, C: $\mathbf{8 8}$

Ching-Yick Tse, E. 15
Coccossis, C. $\mathbf{8 8}$

Connell, J. ro 4

Constantoglou, M. E. 88

Cooper, C. 23, 86

Costa, C. 108

Courtney, P. 89

Crouch, G. I. 14, 15, 67, 69

C

Čomić, Đ. I8

D

Dann, G. 52

Debeljak, Ž. 16

Deery, M. 89

Diedrich, A. 88

Doxey, G. V. 79

du Cros, H. 97

E

Edmunds, J. 98, 107

$\mathrm{F}$

Fletcher, J. 23

Fredline, L. 89

Fyall, A. 12 
G

Garcia-Buades, E. 88

Garrod, B. 12

Getz, D. 33, III

Ghemawat, P. 16

Gilbert, D. 23

Goeldner, R. C. 18, 33, 112

Gunn, C. A. 7, 18, 19, 22, 23, 25, 35

Gursoy, D. 88

\section{$\mathrm{H}$}

Harris, R. 19

Holden, A. 52, 53, 54, 55, 56, 58, 59

Holloway, J. C. 23

136

Howard, J. 19

Howie, F. I2, 17, 73

Hunt, S. D. 15,16

\section{I}

Inskeep, E. 73

$\mathrm{J}$

Jafari, J. 33, II 2

Jago, L. 89

Jeffries, D. J. 2 I

Johns, N. 107

Jurinčič, I. 82

K

Kalmić, L. 18

Krašna, T. 99-138

Kretzschmar, A. 7, 18

Kruczek, Z. I2, 13, 20

Kušen, E. IO, 13, 14, 42, 73

$\mathrm{L}$

Laws, E. 17, 33, 86, 87, 112

Leask, A. 12, 13, 65, 67, 71, 73, 74, 96, 109

Leiper, N. 13, 17, 22, 25, 33, 34, 35, 41, 42, 45, 112

Lew, A. A. 22,65

Loedolff, C. II, 12, I3

Lomine, L. 98, 107

M

MacCannell, D. 21, 22, 25, 29, 33, 47, 48, 49

MacCannellov, D. 29

Magaš, D. 102

Martin, J. D. 18

Mason, P. 76, 80, 8I, 85, 93, 97, 109

Mathieson, A. 82

McCracken, M. $\mathbf{2} 2$

McIntosh, R. V. I8, 33, III

McKercher, B. 97

Middleton, V. T. C. $\mathbf{I 2}, \mathbf{I} 8,22$

Mihalič, T. I4, 102

Mill, R. C. 7, 20, 23, 33, 74, III

Morais, D. B. 89

Morgan, M. 12

Morrison, A. M. 7, 20, 23, 33, 74, 11 I

$\mathrm{N}$

Nadal, J. R. 89

Nunkoo, R. 88

O

Olsen, M. D. I5

P

Page, S. 104

Pearce, P. L. I8, 19, 20, 22

Perez, E. A. 89

Peters, M. 29

Peypoch, N. 34

Pfister, R. E. 89

Phillips, R. G. 90

Pizam, A. 88, 9 I

Poon, A. 17

Poria, Y. 20, 64

Porter, E. M. I5, 16

Prašnikar, J. 16

Pronovost, G. 52 
$\mathrm{R}$

\section{Ramkissoon, H. 88}

Ranchhod, A. 12

Reichel, A. $\mathbf{2 0 , 8 8}$

Richards, G. 29, 39, 4I, 44

Ritchie, J. R. B. I4, 15, 67, 68, 69

Ruhanen, L. 86

Ruzzier, M. 107

S

Scarles, C. 103

Sedmak, G. IoI

Shani, A. 91

Sharpley, R. 7, 20, 54

Smale, W. I2

Solonandrasana, B. 34

Sotiriadis, M. II, I2, I3

Stevens, T. 19

Swarbrooke, J. 12, 18, 19, 53, 73, 81

$\check{S}$

Šturm, P. 107

$\mathrm{T}$

Tajnikar, M. 77

Timothy, D. J. 20

Turner, L. 94

U

Uriely, N. 88

Urry, J. 45, 58

V

Var, T. I8, 19

Veblen, T. 25, 30, 1 II

Vodeb, K. II, 13, 17, 62, 63, 66, 67, 68, 69, 70, 7I, 74, 80, 83, 84, 90, 92, 94,

97, 101, 103, 105, 108, 109

\section{W}

Wagg, S. 26, 58

Wall, G. 72, 82
Walsh-Heron, J. 19

Wang, Y. 89

Wanhill, S. 12, 23, 72

Watson, S. 12

Weidenfeld, A. $\mathbf{I} 2$

Weiermair, K. 29

West, J.J. 15

Wilkinson, P. I2

Williams, A. M. I2

Williams, S. 93

Y

Yale, P. 72

Z
Zins, M. 68

Zorko, D. 18 


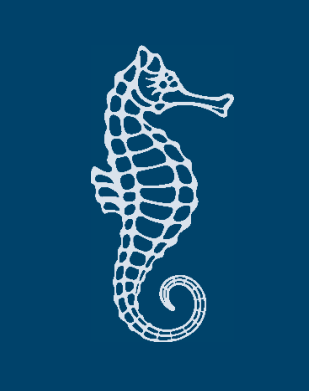

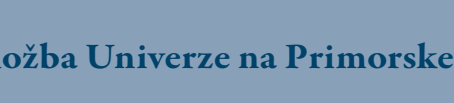

